UNIVERSIDADE DE SÃO PAULO

FACULDADE DE FILOSOFIA, LETRAS E CIÊNCIAS HUMANAS

DEPARTAMENTO DE FILOSOFIA

\title{
Labirintos do Nada: A crítica de Nietzsche ao niilismo de Schopenhauer
}

Jarlee Oliveira Silva Salviano

São Paulo - SP

2006 


\section{Labirintos do Nada: A crítica de Nietzsche ao niilismo de Schopenhauer}

Jarlee Oliveira Silva Salviano

Tese de Doutorado, elaborada sob a orientação da profa. Dra. Maria Lúcia Mello e Oliveira Cacciola, para obtenção do título de Doutor em Filosofia pela Faculdade de Filosofia da Universidade de São Paulo. 
Um grupo de porcos-espinhos num frio dia de inverno se aglomerou para, através do aquecimento recíproco, não morrer de frio. Contudo, logo começam a sentir os espinhos uns dos outros, o que os leva então a se afastarem novamente. Quando a necessidade de aquecimento os aproxima mais uma vez, repete-se aquele segundo infortúnio. Neste vaie-vem em meio aos dois sofrimentos, seguem até encontrarem uma distância segura entre eles, na qual podem melhor suportá-los. Do mesmo modo os homens são impelidos uns aos outros pelas necessidades da sociedade, de cujo seio surgem o vazio e a monotonia. Entretanto, suas particularidades assaz desagradáveis e defeitos insuportáveis os afastam mais uma vez. A distância mediana ao fim encontrada, na qual podem se reunir, são a polidez e os bons costumes (...) Quem no entanto tem muito de seu calor interno prefere ficar longe da sociedade, para não ser incomodado e não causar incômodo.

Arthur Schopenhauer (Parerga e Paralipomena II) 


\section{Agradecimentos}

Meus sinceros agradecimentos à professora Maria Lúcia Cacciola pela atenta e paciente orientação e principalmente pela amizade fraterna no trato com os orientandos; à professora Lore Hühn pela orientação de minha pesquisa em solo germânico; ao meu pai, Jair Salviano (de quem herdei a Vontade), à minha mãe Marliete Silva (pela herança do intelecto) e também à minha filha Hellen, aos meus irmãos e amigos (em especial a Martin Eisermann, Maria Isabel Tyroller e Sophie Guaraci Eisermann), companheiros de luta neste mundo de infortúnio. Agradeço igualmente ao CNPq pelo financiamento da pesquisa (tornando o infortúnio mais suportável). 


\section{À Carine}


SALVIANO, Jarlee Oliveira. Labirintos do Nada: A crítica de Nietzsche ao niilismo de Schopenhauer. São Paulo: Universidade de São Paulo, 2007. (Tese de doutorado)

Resumo: As filosofias da Vontade de Arthur Schopenhauer e Friedrich Wilhelm Nietzsche apresentam duas posturas antagônicas em relação ao sentido da vida. Em ambos a vida deve ser explicada como a expressão de uma força cega e irracional, tornando-se sinônimo de dor e sofrimento - contudo, a reação de cada um diante deste achado filosófico do século XIX os coloca em caminhos contrários. No elogio schopenhaueriano da negação da vontade, da fuga ascética em direção ao Nada, Nietzsche encontra o antípoda de sua filosofia, o niilismo passivo contra o qual propõe o niilismo ativo da afirmação do Eterno retorno.

Palavras-chave: Schopenhauer - Nietzsche - Niilismo - Vontade - Pessimismo Ascetismo

Zusammenfassung: Die Willensphilosophien von Arthur Schopenhauer und Friedrich Wilhelm Nietzsche stellen zwei gegensätzliche Haltungen in Bezug auf den Sinn des Lebens dar. Bei beiden muss das Leben als Ausdruck einer blinden, unvernünftigen Kraft erklärt werden und ist ein Synonym für Schmerz und Leiden jedoch reagieren sie auf diese philosophische Entdeckung des 19. Jahrhunderts in umgekehrter Weise. Nietzsche findet im Schopenhauers Lob der Verneinung des Willens und in der asketischen Flucht zum Nichts den Antipode seiner Philosophie, das heißt, den passiven Nihilismus, gegen welchen er den aktiven Nihilismus der Bejahung der ewigen Wiederkehr vorschlägt.

Schlagwörter: Schopenhauer - Nietzsche - Nihilismus - Wille - Pessimismus Askese

Abstract: Arthur Schopenhauer and Friedrich Wilhelm Nietzsche's philosophies of Will present two contrary positions in relation to the sense of life. In both cases life should be explained as an expression of blind and irrational force, becoming a synonym of pain and suffering - nevertheless, the reaction of each in the face of this philosophic finding of the XIX century, places them in opposing paths. In the Schopenhaueran commendation to the denial of will, of self-denying escape in the direction of Nothing, Nietzsche finds the opposite to his philosophy, passive nihilism against which he proposes active nihilism of the affirmation of the Eternal return.

Key-Words: Schopenhauer - Nietzsche- Nihilism - Will - Pessimism - Asceptism 


\section{SUMÁRIO}

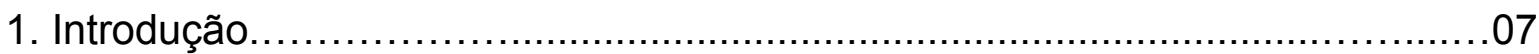

2. Do mundo como Vontade à Ética da compaixão.............................12

I. A Vontade de viver como essência do mundo................................ 12

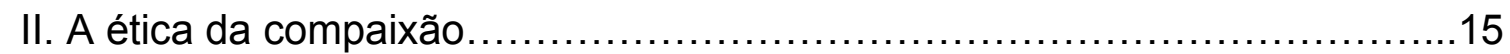

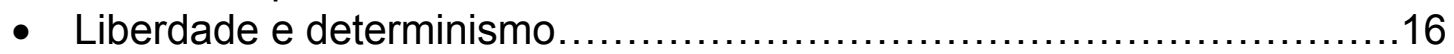

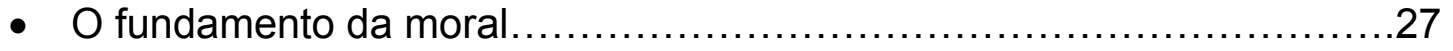

- Pessimismo e niilismo: a negação da vontade ........................................49

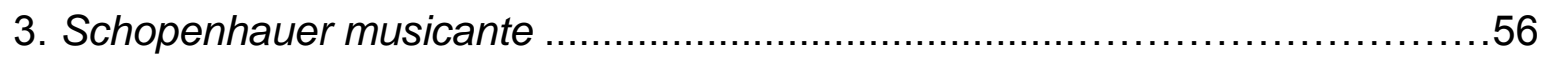

I. A metafísica do belo e o acesso à coisa em si.............................56

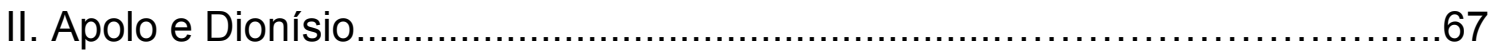

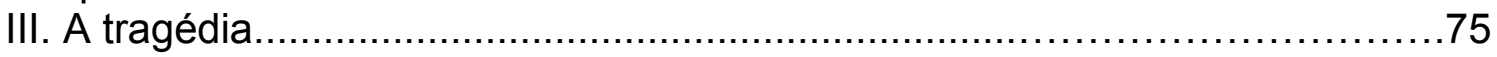

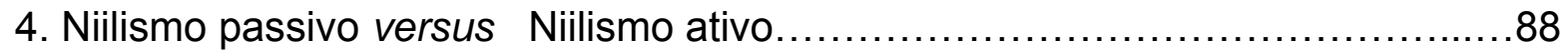

I. A saúde da filosofia..........................................................

II. Ausgangslosigkeit: os labirintos do nada não têm saída........................104

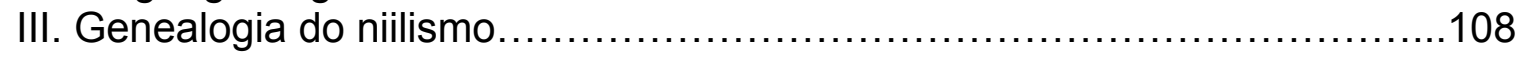

5 . Mais algumas aproximações: explícitas ou não tão explícitas........................117

- A questão do estilo................................................................ 117

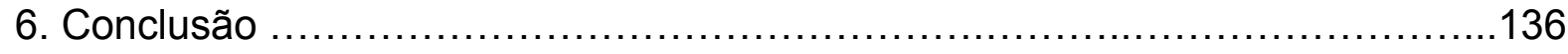

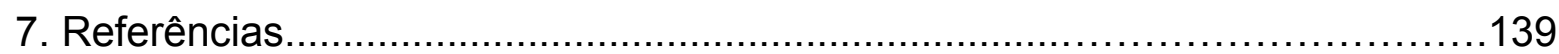




\section{INTRODUÇÃO}

Cada linha deste trabalho foi escrita com a consciência do risco sempre à espreita, o qual acompanha uma pesquisa filosófica que se atém a uma temática deste tipo, conforme nos alertam as severas palavras de $A$ gaia ciência: "quem quer mediar entre dois pensadores decididos mostra que é medíocre: não tem olhos para o que é único; enxergar semelhanças e fabricar igualdades é característica de olhos fracos" (NIETZSCHE, 2001, p. 177). Neste sentido, talvez não fosse incoerente indagar, em relação à prática filosófica atual, até que ponto estende-se a mediocridade de nossa labuta acadêmica. Qualquer mediação entre um pensador (decidido ou não) e o leitor já não seria mediocridade? No entanto, a despeito da aspereza da crítica nietzschiana, o presente escrito pretende tratar desse importante passo do caminhar da história da filosofia que são as obras de Schopenhauer e Nietzsche. Por outro lado, se perdoamos também os grandes nomes da filosofia (desde os gregos) por este "ato de mediocridade", convém aqui igualmente verificar a eficácia da empreitada: servimo-nos dos filósofos como nossos educadores (tomando de empréstimo ainda a terminologia nietzschiana); analisando o embate entre os pensamentos de dois autores, adentramos a casa de máquinas da filosofia, visualizamos os contornos não aparentes de seu processo, verificamos de que modo características de um determinado contexto filosófico, em sua riqueza infindável, fazem explodir em diferentes espíritos uma miríade de soluções diferenciadas aos problemas que a vida nos impõe. 
As aproximações aqui empreendidas ocorreram com o devido cuidado diante da fabricação de igualdades, como diz Nietzsche, sem deixar de notar, entretanto, que o contrário também deveria ser reprovável: pois se negligenciamos o discurso comum em que se expressam dois pensadores, privamo-nos de perceber as sutis nuanças que se desenham nesta luta - às vezes violenta travada em nome da auto-afirmação de um pensamento e no conseqüente ultrapassamento dos elementos estranhos ao contorno de uma espiritualidade. Para isto, diríamos, é preciso olhos fortes.

Isto posto, resta-nos apresentar os caminhos que foram trilhados neste estudo, bem como sua metodologia e limitações.

É conhecida a relação direta (ou indireta) das filosofias da vontade de Schopenhauer e Nietzsche com o idealismo pós-kantiano do qual o primeiro foi contemporâneo. No entanto, a pesquisa orientou-se pela atenção às obras dos dois filósofos e na tentativa de delimitar o tema à crítica de Nietzsche ao niilismo de Schopenhauer - salvo quando foi necessária uma menção às filosofias de Fichte, Hegel ou Schelling. A propósito, talvez devido ao fato de que Schopenhauer não tenha utilizado uma vez sequer o termo em questão (ao passo que ele já se fazia presente nos primórdios da filosofia pós-kantiana, em Jacobi especialmente, mas também no jovem Hegel) não encontramos até o momento entre os estudiosos da filosofia schopenhaueriana qualquer referência ao "niilismo" do autor de $O$ mundo como vontade e representação, mesmo nos comentários sobre o fenômeno da "negação da vontade" no âmbito de sua ética. Sendo assim, se em Nietzsche encontramos uma crítica ao niilismo de Schopenhauer cabe verificar o que se entende aqui por este termo.

Se encaramos o conceito como uma teoria do Nada, observaremos que de fato há um niilismo em Schopenhauer, que o filósofo esboça tal teoria nas últimas 
linhas de sua obra capital. A hipótese que nos serve de ponto de partida na presente pesquisa pretende mostrar que o negativismo criticado por Nietzsche em seu antecessor não consiste numa problematização desta teoria do parágrafo 71 de 0 mundo. A pergunta "o que é o Nada", enquanto objeto do pensamento, não interessa a Nietzsche senão enquanto revele de algum modo a face oculta das filosofias que são a expressão de certo sentimento de nada, de uma desvalorização da vida. Por trás do acirrado jogo lógico-conceitual que envolvia certos objetos cognitivos como o Nada, o Absoluto ou mesmo o Ser, na filosofia da primeira metade do século dezenove, coube a Nietzsche desvelar as raízes psicológicas das couraças epistêmicas dos sistemas filosóficos. Para tanto, torna-se necessário adentrar a penumbra que envolve os labirintos do nada - não esquecendo de levar como auxílio o novelo de lã de Teseu.

Sabendo que as investidas do autor de Assim falou Zaratustra a Schopenhauer têm como foco a Ética da compaixão deste último, procuramos analisar, no capítulo inicial, a filosofia schopenhaueriana com o olhar atento para a importância e o significado deste conceito em sua Ética. Para isto foi preciso perscrutar as bases epistemológicas de sua teoria sobre a moralidade visando mostrar que, em Schopenhauer, esses dois âmbitos são inseparáveis. Ademais, o tríplice modelo kantiano: Teoria do conhecimento-Ética-Estética, sobre o qual é erigido o edifício filosófico schopenhaueriano (não exatamente nesta ordem), é analisado a partir desta problemática da negação da vontade. A principal tarefa que se impõe nesta análise consiste no delineamento dos limites e na verificação das relações em que se apresentam estas expressões da atividade humana (o conhecimento, a moral e o sentimento do belo) e como o fenômeno da negação da vontade pode ser entendido em cada uma. 
O nuclear e espinhoso problema que se manifesta no decorrer desta pesquisa diz respeito à classificação do niilismo schopenhaueriano como passivo, dado que em Schopenhauer encontramos uma definição da compaixão como uma atividade. Sendo assim, cumpre-nos verificar o estatuto desta passividade na classificação nietzschiana e o lugar nela ocupado pelo pensamento schopenhaueriano. Não nos propusemos, para isto, uma exaustiva classificação e análise das fases do pensamento Nietzschiano. No entanto, uma especial ênfase ao primeiro escrito O nascimento da tragédia será dado no capítulo Schopenhauer musicante na busca de uma problematização do uso do instrumental conceitual schopenhaueriano por Nietzsche ainda quando é explícita a tentativa de uma radical contraposição. Partimos do pressuposto de que a Estética de ambos se sustenta nesta base comum da crítica aos limites da linguagem científica e na proposta de um acesso à verdade pela via da experiência artística.

No capítulo final Niilismo passivo versus niilismo ativo, vários elementos da argumentação anterior encontram seu arremate na crítica psicológica do último Nietzsche à filosofia de Schopenhauer, bem como são revisados alguns conceitos chaves do pensamento nietzschiano (Vontade de poder, Eterno retorno, Superhomem etc.) a partir desta relação com Schopenhauer e da tentativa de elaboração de uma filosofia afirmadora da vida, fenomenista e destruidora dos valores antigos. Com isto, é apresentada a tese principal deste trabalho, na qual se mostra como a distinção schopenhaueriana entre o fenômeno da moralidade e o do ascetismo (distinção esta não enfatizada pelos estudiosos de Schopenhauer) estende-se também ao pensamento nietzschiano.

Nesta perspectiva procuramos analisar, no último capítulo, que trata da questão do estilo, em que sentido as palavras de Nietzsche em relação a seu exeducador descrevem de fato o pensamento schopenhaueriano, assim como apontar 
para a cautela necessária na verificação da eficácia da acusação (como bem prescreve Alain Roger no prefácio de uma tradução francesa do Ensaio sobre o fundamento da moral de Schopenhauer). 


\section{DO MUNDO COMO VONTADE À ÉTICA DA COMPAIXÃO}

\section{A VONTADE DE VIVER COMO ESSÊNCIA DO MUNDO}

A Ontologia da vontade do autor de $O$ mundo como vontade $e$ representação encontrou na Crítica kantiana o instrumental conceitual a partir do qual suas bases epistemológicas foram erigidas. Sua teoria do conhecimento tem como ponto de partida a distinção operada por Kant entre o princípio transcendental, isto é, a faculdade pela qual o sujeito percebe a realidade fenomênica ou o objeto de toda experiência possível, no qual o modo de existência já está sempre determinado a priori pelas leis pertencentes à própria faculdade do conhecimento; e o princípio lógico, que pertence à razão e tem como objeto os conceitos. Temos aí a origem da distinção schopenhaueriana entre conhecimento abstrato e conhecimento intuitivo.

Para Kant, como para Schopenhauer, o espaço e o tempo não são princípios extraídos da experiência sensível, como o queria o empirismo, mas formas a priori do conhecimento: são como lentes unicamente pelas quais os objetos nos são dados. Entretanto, observa Schopenhauer, na Crítica kantiana elas se apresentam como formas da sensibilidade: faculdade em que aquilo que nos é dado, o conteúdo do conhecimento (que para o Idealismo é gerado no sujeito cognoscente), a coisa em si, ganha as marcas da temporalidade e da espacialidade. 
Ela será então, em Kant, a faculdade da intuição. O entendimento é a faculdade do juízo: o conjunto das doze categorias extraídas da tábua dos juízos que Kant foi buscar na lógica aristotélica. Estas categorias (distribuídas em quatro classes: quantidade, qualidade, relação e modalidade) seriam a segunda lente pela qual o entendimento imprimiria novas formas às representações intuitivas dadas pela sensibilidade, constituindo os objetos da experiência já sob as formas do espaço e do tempo. Portanto, na filosofia kantiana a intuição empírica (dados dos sentidos) e a intuição pura (formas a priori da sensibilidade) são funções da sensibilidade. Schopenhauer por sua vez não credita à sensibilidade qualquer faculdade de intuição, ela apenas oferece a matéria (Stoff) que servirá para a aquisição das representações intuitivas - tarefa do entendimento (ou intelecto), no qual se encontram as formas a priori do espaço e do tempo, que serão regidas pelo princípio de causalidade.

O princípio de causa e efeito é então o único que resta no entendimento do conjunto de doze categorias kantianas. As onze demais categorias só existem como conhecimento abstrato (da razão) e não intuitivo (do intelecto). Enquanto juízos, as categorias não têm no entendimento uma função correlativa a cada uma delas: "eu exijo", diz Schopenhauer na Crítica da filosofia kantiana, "que, das categorias, atiremos onze pela janela e só conservemos a da causalidade" (SCHOPENHAUER, 1980, p. 112). Na razão não existe nada que não tenha sido extraído do entendimento, ou seja, é tão somente na representação intuitiva que a representação abstrata encontra sua fonte. Assim, "todo o conceito existe e tem valor apenas enquanto está em relação, tão longínqua quanto se queira, com uma representação" (SCHOPENHAUER, s/d-b, p. 92).

Se o intelecto é a faculdade das representações empíricas intuitivas originadas nos dados da sensibilidade e a razão é a faculdade dos conceitos ou 
representações abstratas meramente extraídas do intelecto (com suas formas do espaço, tempo e causalidade), resta-nos a conclusão inevitável de que o mundo como ele é em si mesmo, a essência de toda a realidade fenomênica (sendo esta, pois, produzida pelo intelecto), não é acessível ao conhecimento.

O que seria então esta realidade que se esconde por trás do Véu de Maya $^{1}$ ? Se o conhecimento voltado para o exterior só proporciona ao sujeito meras representações, a chave deste enigma deverá ser encontrada no autoconhecimento deste mesmo sujeito. Sendo assim, é no próprio corpo que o sujeito que conhece encontrará uma pista para esta outra realidade. No entanto, o corpo é (ele também) apenas uma representação informada pelo tempo e pelo espaço. Há, todavia, algo neste conhecimento reflexivo que escapa a toda tentativa de perscrutação da razão; algo nesta reflexão permanece ainda imaculado pelas formas do conhecimento sensível (e, por conseguinte, pelo conhecimento abstrato): tudo aquilo que, inconsciente no corpo, pode ser tão somente sentido. A este algo damos o nome geral de Vontade. Ora, pensa analogicamente Schopenhauer, se esta instância inconsciente no corpo é indiferente às formas do intelecto, só pode ser ela a essência metafísica antes buscada, não só no homem, mas em todo o universo, ou seja, é no querer cego de cada um que encontramos a realidade que serve de fundamento ao mundo como representação. Se o corpo é, por um lado, representação, matéria, por outro, esta mesma matéria, independente das formas do intelecto, é Vontade ${ }^{2}$.

O mundo fenomênico é Vontade objetivada, o que torna toda satisfação uma satisfação da Vontade em si mesma: este ímpeto cego (blinder Drang) quer

\footnotetext{
${ }^{1}$ Abundam em Schopenhauer as fórmulas extraídas do hinduísmo, segundo ele a religião que melhor poderia representar a sua filosofia, e que o faz ganhar o título de "budista extraviado no Ocidente" (RIBOT, 1874, p. 12). ${ }^{2}$ Deve-se notar, todavia, que na sua Dissertation de doutorado, Sobre a quádrupla raiz do princípio de razão suficiente (1813), Schopenhauer ainda não chegara à idéia da Vontade metafísica - tampouco se pode pensar ali na vontade individual como caráter inteligível, a Idéia platônica, trata-se aqui apenas do querer fenomênico, a vontade já travestida sob a forma do tempo, que ganhará o nome de caráter empírico. A visão do mundo como Vontade tem sua primeira aparição, antes mesmo de $O$ mundo, em fragmentos póstumos de 1814.
} 
infinitamente e, dado que fora da Vontade e da representação (o fenômeno) nada existe, precisa saciar-se em si mesmo, daí o conflito que infalivelmente marca todos os âmbitos da natureza. Ela é um monstro que morde a própria cauda. "Em toda a parte na natureza", afirma o filósofo, "nós vemos luta, combate, e alternativas de vitória, e deste modo nós chegamos a compreender mais claramente o divórcio essencial da Vontade com ela mesma" (SCHOPENHAUER, s/d-b, p. 191) ${ }^{3}$. A consciência, no homem, é sempre governada por esta força inconsciente. O cérebro, sede do conhecimento (como todo o organismo) é uma criação da Vontade de viver (Wille zum Leben), um instrumento para a sua satisfação: "a consciência é apenas a superfície do nosso espírito; do mesmo modo que em relação à terra nós só conhecemos a crosta, não o interior" (SCHOPENHAUER, s/d-b, p. 270).

Deste modo, ainda que trágico, Schopenhauer conduz a filosofia do céu para a terra com sua metafísica imanente: ela será então "deslocada do suprasensível para a experiência interior que cada um tem de seu próprio corpo em ação, surgindo, da impossibilidade mesma de uma metafísica transcendente, a metafísica imanente que decreta a ausência de Deus e a presença do homem como ser corporal finito" (CACCIOLA, 1994, p. 23).

Cabe então verificar como, em sua ética e em sua estética, Schopenhauer desenvolve essa questão aqui descoberta do mundo como Vontade.

\section{A ÉTICA DA COMPAIXÃO}

\footnotetext{
${ }^{3}$ Pode-se facilmente constatar que "o universo está em luta por nada" (PHILONENKO, 1999, p. 102). "Não há ordem nem razão do ser, toda existência repousa sobre um princípio obscuro e irracional", comenta Didier Raymond em seu artigo L'Iconoclaste (In: SIPRIOT, 1988, p. 40).
} 
Excetuando os complementos contidos nos Parerga e paralipomena, os elementos fundamentais que compõem a ética schopenhaueriana são expostos no quarto livro de $O$ mundo como vontade e representação e nos dois escritos para os concursos das Academias da Noruega e da Dinamarca, respectivamente, Sobre a liberdade da vontade ${ }^{4}$ (1839, premiado) e Sobre o fundamento da moral (1840, não premiado, apesar de concorrente único), publicados juntos em 1841 sob o título Os dois problemas fundamentais da ética.

Três temas centrais percorrem as linhas destes escritos: a liberdade, a compaixão como fundamento da moral e a negação da vontade.

- Liberdade e determinismo

Para Schopenhauer a idéia de uma liberdade absoluta do querer, de um liberum arbitrium indifferentiae, é simplesmente impensável. Com isto o filósofo responde negativamente à questão colocada pela Sociedade Real de Ciências norueguesa. Nenhum dado da consciência externa ou interna revela a possibilidade do livre arbítrio. Tal dogma fora uma ilusão alimentada pela ética tradicional (aqui bem representada pela filosofia cartesiana), que Schopenhauer pretende refutar lançando mão da teoria kantiana da coexistência da liberdade e da necessidade: a primeira, pertencente ao mundo em si; a segunda, relegada ao fenômeno.

A idéia de um querer livre remeteria ao pensamento de um agir sem necessidade, sem uma causa que o antecedesse - necessário é assim, afirma ele,

${ }^{4} \ddot{U} b e r$ die Freiheit des Willens, traduzido para o francês por Salomon Reinach com o título infeliz: Essai sur le libre arbitre. 
"tudo o que resulta de uma razão suficiente dada" (SCHOPENHAUER, 1925, p. 9). Em bom jargão schopenhaueriano: agir livre seria um agir sem motivos. No entanto, toda ação se dá no tempo, no espaço e regida pelo princípio de causalidade; assim como na matéria inorgânica, todo acontecimento no reino vegetal ou animal ocorre de forma determinada, dentro de uma cadeia de causas e efeitos que liga todos os seres do mundo fenomênico. A expressão "eu posso fazer o que eu quero" não afirma nada além da ligação necessária entre a volição e as ações corporais ${ }^{5}$. A relação desta volição com os motivos é algo completamente diferente e é nela que deve ser investigada, diz o filósofo, a questão da liberdade. A mera ausência de obstáculos (potência de agir, liberdade física) não pode ser entendida como ausência de motivos; estes estão relacionados à potência de querer (liberdade moral). Toda ação humana (todo ato volitivo) se afetua portanto determinada por um único motivo dado, dentro da mais rígida necessidade. Pode-se desejar coisas diferentes e até opostas entre si, mas só se pode querer uma coisa, decisão que cabe à vontade de cada indivíduo que, determinada pelos motivos, já decidiu antes da atuação da consciência.

A lei da causalidade (Kausalität), também chamada por Schopenhauer em sua Tese de doutoramento de princípio de razão suficiente, é compreendida aqui de três modos diferentes de acordo com a classe de objetos a que se dirige:

1) Causalidade (Ursächligkeit) em sentido estrito (realidade empírica) também chamada princípio de razão suficiente do devir (rationum fiendi).

2) Lei lógica (silogismos), ou princípio de razão do conhecimento (rationis cognoscendi).

3) Lei matemática (tempo e espaço puros, objetos da geometria), ou princípio de razão do ser (rationum essendi).

${ }^{5}$ Operari sequitur esse (o que se faz segue-se do que se é), diz a fórmula escolástica empregada por Schopenhauer. 
É deixado de lado então o quarto princípio da "quádrupla raiz" de 1813, a lei da motivação ou princípio de razão suficiente do agir (rationis agendi) (conforme classificação feita por Wollf). Esta é apresentada neste novo contexto como uma das três formas da causalidade empírica, sendo as outras duas a causa (Ursache) (inorgânico: podendo ser mecânica, física ou química) e a excitação (vegetais).

A lei da motivação rege toda a natureza animal. A vontade nela atua mediante o conhecimento que é guiado pelos motivos ou representações, sendo estas sensíveis ou abstratas (no homem). Através da fixação da percepção em conceitos, representações abstratas, a razão permite ao homem guiar-se por outros motivos que não os meramente presentes, aumentando seu campo de atuação e através da deliberação (Deliberationsfähigkeit) e do confronto dos motivos $^{6}$ possibilitando o que Schopenhauer chamará de liberdade relativa, onde a necessidade continua vigindo:

\begin{abstract}
Esta liberdade relativa, na realidade, não é outra coisa que a liberdade da vontade, tal como o entendem as pessoas instruídas mas pouco habituadas a pensar com profundidade: elas reconhecem com razão nesta faculdade um privilégio exclusivo do homem sobre os animais. Mas esta liberdade é apenas relativa, porque ela nos subtrai à pressão dos objetos presentes, e comparativa, o que nos torna superiores aos animais. Ela modifica apenas a maneira como se exerce a motivação, mas a necessidade da ação não é suspendida de forma alguma, nem mesmo diminuída (SCHOPENHAUER, 1925, p. 70-1).
\end{abstract}

Um objeto que, subtraído à sua posição de equilíbrio, oscila de um lado para o outro procurando seu centro de gravidade para precipitar-se em sua direção, pode ser equiparado a uma decisão deliberada determinada por motivos, sejam eles sensíveis ou abstratos (lembrando que estes últimos são originados dos primeiros). Sendo assim, podemos dizer com Schopenhauer que, na escala ascendente dos seres, a causa das ações se torna cada vez menos material e palpável, perde força,

\footnotetext{
${ }^{6}$ Velleitas (Willensregung): representar o motivo de uma das ações como possível (SCHOPENHAUER, 1925, p. 85).
} 
ao passo que o efeito se fortalece cada vez mais. Isto significa que percebemos com mais dificuldade a ligação de um efeito à sua causa, à medida que ascendemos ao mundo abstrato dos conceitos. No animal esta ligação causal é sensível, imediata, quase mecânica; no homem, é praticamente imperceptível: "por isso é que o motivo que também o move com necessidade não aparece para o espectador ao mesmo tempo em que a ação. Leva-o oculto na cabeça" (SCHOPENHAUER, 2001c, p. 59). Mas ela não deixa jamais de estar presente, com o mesmo poder necessitante com a exceção do estado ascético, da negação completa da vontade, não analisada em ambos os escritos de 1841.

Num apelo à imaginação do leitor (recurso constante em Schopenhauer) o filósofo elabora um exemplo que ilustra sua refutação do livre arbítrio. Ele pede para imaginarmos um cidadão qualquer que andando pelas ruas, após uma jornada de trabalho, detém-se e começa a refletir em voz alta sobre a sua pretensa absoluta liberdade de arbítrio, que o possibilitaria, diante de uma série de ações (ir a teatro, passear, sair da cidade a vagar sem rumo mundo afora, etc.) que o seu entendimento colocara diante de si, escolher qualquer uma delas. No entanto, diz ele, "escolho ir para casa, para junto de minha esposa". Daí a um instante, ver-se-ia surgir por detrás do cidadão o filósofo que indagaria a pretensa liberdade de arbítrio deste homem, o qual tenderá de todas as formas negar qualquer aspecto de necessidade que poderia determinar sua vontade em relação a um motivo dado, afirmando, para provar o contrário, poder executar uma outra alternativa diferente da escolhida anteriormente. Ora, dirá Schopenhauer, ainda aqui um motivo determinou a atitude do indivíduo: a própria indagação do filósofo, "pois neste caso fora justamente a expressão de minha dúvida e a influência que exerceu sobre seu espírito de contradição, que teria sido o motivo determinante de sua ação" (SCHOPENHAUER, 1925, p. 86). 
Por trás daquelas expressões da causalidade relativas ao inorgânico e aos vegetais (explicáveis pela ciência), esconde-se a inescrutável obscuridade das forças (Kräfte): naturais, no que diz respeito à matéria inorgânica; e vitais, em relação aos vegetais. Graças ao conhecimento, no homem a mesma força primária (neste caso, a vontade) pode ser percebida por dentro e imediatamente. No entanto, o conhecimento exato da manifestação desta vontade no indivíduo só pode ser conseguido a posteriori, pela experiência. Estas forças (natural, vital e a vontade no homem) são graus intermediários entre a Vontade como coisa em si e os fenômenos, são objetivações imediatas da Vontade (enquanto os fenômenos são objetivações mediatas) e serão chamadas, como foi dito, de Idéias. Esta força constituinte da essência humana ganha então uma dimensão metafísica que será denominada de caráter inteligível. Seguindo orientação de Kant, em Schopenhauer a manifestação deste caráter inteligível no corpo ganha o nome de caráter empírico ${ }^{7}$. O conhecimento exato do caráter (a consciência de suas limitações) será chamado de caráter adquirido (erwobener Charakter).

O caráter empírico (primitivo, inalterável e impenetrável como as forças naturais e vitais) pode ser entendido a partir de quatro características essenciais: 1)INDIVIDUAL - difere de indivíduo para indivíduo no ser humano, enquanto nos outros animais vê-se o predomínio da espécie; 2)EMPíRICO - cognoscível somente através de sua manifestação na experiência; 3)CONSTANTE - permanece o mesmo por toda a vida; e 4)INATO - deste modo pode Schopenhauer explicar porque duas crianças nascidas nas mesmas circunstâncias, criadas no mesmo ambiente cultural, apresentam caráter distintos. O caráter é herdado, diz o filósofo, mas tão somente do pai (sendo o intelecto de herança materna).

\footnotetext{
${ }^{7}$ Apesar da menção a Kant, Schopenhauer reconhece, já em Platão, a presença da distinção entre caráter inteligível e empírico, ainda que ligada à metempsicose (SCHOPENHAUER, 2001c, p. 98)
} 
Contra toda prescritibilidade da ética na filosofia, Schopenhauer defende que a filosofia tem um caráter eminentemente teórico, não Ihe cabendo, no campo da ética, a prescrição da conduta na vida. O papel de investigadora imparcial é concedido à filosofia moral, pois para ele o caráter (onde as ações encontram sua origem), sendo inato, não pode ser educado: "a virtude não se aprende, não mais do que o gênio" (SCHOPENHUAER, s/d-b, p. 357). A filosofia deve apenas traduzir in abstracto o que ocorre in concreto no sentimento. Segundo ele uma moral prescritiva não teria mais razão de ser num período pós-ilustração - de acordo com a definição kantiana da Aufklärung como entrada na maioridade, dirá Schopenhauer:

Quando se fala às crianças, aos povos que ainda estão na infância, isso é bom, mas com pessoas que vivem numa época de civilização, de razão, de maturidade e que são do seu tempo, não! É contradizer-se, - é muito difícil vê-lo? - chamar à vontade livre, para em seguida lhe impor leis, leis segundo as quais tem de querer; "tem de querer!" o mesmo é dizer ferro de madeira! (SCHOPENHAUER, s/d-b, p. 358-9).

Em sua caminhada pela senda dos conceitos a filosofia deve se contentar em mostrar, dirá Schopenhauer, que o homem, como todo o universo, é essencialmente Vontade (como o filósofo nos mostra desde o segundo livro de 0 mundo), que o corpo nada mais é que fenômeno, a objetivação imediata da vontade individual, e que o homem se distingue do restante dos animais num aspecto essencial, a saber, em que nestes as individualidades fenomênicas são objetivações de uma mesma Idéia (a espécie) enquanto aquele tem uma Idéia particular. Em suma (e analisando a questão das forças citada acima sob a perspectiva da antropologia metafísica schopenhaueriana), pode-se afirmar que o conceito de Vontade em sua filosofia pode ser entendido em dois sentidos diferentes mas complementares: como coisa em si ou Vontade numênica; ou como vontade individual ou Idéia platônica. Esta vontade individual, por sua vez, deixa-se perceber em três aspectos distintos, conforme classificação acima: enquanto caráter 
inteligível, que é a vontade individual propriamente dita, fora do tempo e do espaço; enquanto caráter empírico ou manifestação (no tempo) do primeiro: mero querer que se dá através da conduta humana; e, finalmente, o caráter adquirido: trata-se do caráter que se forma na vida prática, ou seja, pela experiência, através da reflexão, o indivíduo fenomênico compreende a imutabilidade de sua vontade individual, podendo resignar-se quanto aos limites e o alcance de suas ações no mundo como representação. O caráter inteligível se dá fora do tempo sendo assim alheio à mudança; e como o caráter empírico é apenas manifestação daquele, o filósofo afirmará que a ética não molda o sujeito, não forma virtuosos, como a estética não forma gênios, pois ambos são expressões do caráter imutável dos indivíduos - de acordo com a máxima de Sêneca tomada emblematicamente por Schopenhauer para traduzir esta tese: Velle non discitur (o Querer não se aprende) (SCHOPENHAUER, s/d-b, p. 388).

Inverte-se deste modo a tradicional relação estabelecida entre a vontade e o intelecto. Esta revolução, cujo impacto na ética é destruidor, consiste em mostrar que a vontade é a parte primitiva e essencial no homem, sendo o intelecto formado bem depois. Desmorona-se desta forma a concepção socrática (e de quase toda a filosofia da moral antiga) de virtude enquanto a atualização da racionalidade originária do homem, presente no conceito de alma, que é identificada com a consciência. Schopenhauer critica, neste sentido, Descartes e Espinosa, para os quais a vontade seria posterior ao intelecto, sendo mesmo uma parte deste, uma espécie de juízo volitivo, e que a partir da deliberação (do pensamento) sobre a bondade ou não de uma coisa, passaríamos a querer ou não tal coisa. E nisto consistiria o caráter, que seria assim formado pelas circunstâncias e pela cultura: visão surpreendente, que apresenta o homem como um zero moral no momento do nascimento. Pelo contrário, sentencia Schopenhauer, "todo o homem deve à sua 
vontade ser o que é; o seu caráter existe nele primitivamente, visto que o querer é o próprio princípio do seu ser" (SCHOPENHAUER, s/d-b, p. 386). Além do mais, naquele caso a questão da responsabilidade moral se tornaria difícil de ser pensada, atuando o acaso ou a Providência; e seríamos também levados a constatar que o caráter se formaria tarde demais: "a maioria dos homens morreria antes de ter um caráter" (SCHOPENHAUER, 1925, 113). O homem primeiro quer uma coisa, só depois a declara boa. Entre duas alternativas a vontade já fez sua escolha antes que a faculdade do juízo começasse a trabalhar. A propósito, o cérebro (fonte do entendimento) é um órgão que se forma para satisfazer o anseio da vontade de conhecer; é apenas um mero instrumento (como todo o organismo) ${ }^{8}$.

A liberdade de escolha ou faculdade de deliberar nada mais é do que dispor os motivos da intuição em conceitos abstratos e promover o conflito entre eles, podendo mover sua imaginação para o passado e para o futuro, aumentando consideravelmente a gama de motivos $^{9}$. No entanto, no final das contas é sempre a vontade que decide: "até que enfim o motivo mais forte obriga os outros a lhe ceder o lugar e determina isoladamente a vontade" (SCHOPENHAUER, 1925, p. 72). Tendo em vista que o querer é sempre dirigido pelos motivos, ocorre que toda ação é determinada, não existindo a possibilidade de um liberum arbitrium indifferentiae.

\footnotetext{
${ }^{8}$ Clément Rosset vê nesta tese da obediência do intelecto em relação à vontade, "o ponto de partida de uma filosofia genealógica (Marx e Nietzsche), assim como de uma psicologia do inconsciente (Freud)" (ROSSET, 1989, p. 35). Um exemplo notável pode ser percebido nesta passagem de Sobre o fundamento da moral: "Se quisermos chegar ao fundamento da admissão da razão prática, teremos de explorar ainda mais sua árvore genealógica. Acharemos então que ela procede de uma doutrina que o próprio Kant contradisse profundamente, mas que, no entanto, encontrava-se, mesmo que inconscientemente para ele, como reminiscência de um modo de pensar precedente, no fundamento de sua admissão de uma razão prática com seu imperativo e sua autonomia". (SCHOPENHAUER, 2001c, p. 63)

${ }^{9} \mathrm{O}$ fato de o homem dispor de um tipo de motivo a mais que os outros animais possibilita, por um lado, a chamada liberdade relativa, mas significa também um acréscimo de elementos que contribuem para o seu desassossego, pois são os motivos a causa de todo o sofrimento no mundo. Ademais, alguns motivos abstratos (uma lembrança desagradável, uma expectativa de mau negócio etc.) atormentam muito mais que algumas dores físicas: "eis porque, nas horas de aflição arrancamos os cabelos, batemos no peito, dilaceramos o rosto, rolamos no chão: tantos artifícios violentos para aliviar o nosso espírito dum pensamento que o esmaga" (SCHOPENHAUER, s/d-b, p. 394).
} 
"Tudo o que ocorre", segundo o filósofo, "das menores às maiores coisas, ocorre necessariamente" (SCHOPENHAUER, 1925, p. 122) ${ }^{10}$.

Ademais, para o autor de O mundo nenhuma instrução muda o querer de alguém. O que se quis uma vez, assim o será para sempre. "Sêneca não foi o preceptor de Nero?", pergunta impacientemente Schopenhauer (SCHOPENHAUER, 1925, p. 110). Tentar corrigir os defeitos do caráter através de discursos e sermões de moral é para ele como querer transformar chumbo em ouro, que um carvalho produza damasco ou "esperar que a mesma árvore que no último verão produziu cerejas, no próximo produza pêras" (SCHOPENHAUER, 1925, p. 117); ou ainda: tentar "dissuadir os gatos de sua inclinação para os ratos" (SCHOPENHAUER, 2001c, p. 189). Numa crítica ao próprio Schopenhauer, encontramos uma interessante imagem em Nietzsche que pretende se contrapor à crença dos ressentidos e seu apego à idéia do livre-arbítrio: eles crêem que "o forte é livre para ser fraco, e a ave de rapina livre para ser ovelha" (NIETZSCHE, 1998, p. 36-7).

O que realmente muda em relação ao caráter é apenas a sua direção, provocada pela força dos motivos, nunca o que ele é essencialmente em si. o veredicto da inalterabilidade de nossa essência não leva, no entanto, o filósofo a rejeitar todo tipo de tentativa de trabalho de melhoria dum caráter. Uma vez que não conhecemos nossa vontade antecipadamente, mas só pela experiência, na vida, isto deve ser uma razão para trabalharmos na região do tempo, lutar para fazer com que este quadro no qual acrescentamos uma pincelada a cada ação no mundo dos fenômenos, seja feito para nos serenar, não para nos atormentar, diz ele. A

\footnotetext{
${ }^{10}$ Neste fatalismo schopenhaueriano todo o percurso da vida do indivíduo será tomado como predeterminado, pois os acontecimentos são como os caracteres de um livro: estão já lá antes que coloquemos os olhos neles - daí a crença de Schopenhauer nas previsões (Vorhersehn, Antecipationen) do futuro: "tudo está infalivelmente determinado de antemão (vorherbestimmt) pelo destino" (SCHOPENHAUER, s/d-b, p. 398). Para os que se espantam com a tese da necessidade absoluta, que sejam dirigidas as palavras apascentadoras de Schopenhauer: é ela fonte de profundo consolo e tranqüilidade.
} 
modificação que se dá aqui diz respeito apenas aos meios, às vias que levam ao motivo visado.

Para o caráter inato de cada homem, portanto, os fins em geral em direção aos quais se tende invariavelmente estão já determinados em sua essência: os meios aos quais ele recorreu para aí chegar são determinados tanto pelas circunstâncias exteriores como pela compreensão que se tem delas, visão da qual a justeza depende por sua vez do entendimento e da cultura. O indivíduo se torna assim "capaz de ver as mesmas circunstâncias de uma maneira mais exata e completa" (SCHOPENHAUER, 1925, p. 106). Chega-se, deste modo, a uma certa clareza de consciência (Besonnenheit) ou consciência moral (Gewissen) que marca o caráter adquirido, requisito necessário para se estar de posse daquela liberdade relativa ou liberdade intelectual. Nessa liberdade, o intelecto apresenta à vontade os motivos em sua pureza, sem obstáculos, ou seja, sem a má influência de causas exteriores ou de um entendimento perturbado (delírio, loucura, paroxismo, paixão, embriaguez...), o que torna a ação em certa medida justificável moral e juridicamente - neste caso "a responsabilidade passa da vontade para o intelecto" (SCHOPENHAUER, 1925, p. 198). A caracterização do indivíduo tomado pela paixão ou embriaguez e desprovido da liberdade intelectual, feita por Schopenhauer, poderia adequadamente servir a Nietzsche em sua descrição da embriaguez dionisíaca em O nascimento da tragédia. De fato, afirma Schopenhauer, na paixão e na embriaguez ocorre o fortalecimento dos motivos sensíveis e o enfraquecimento dos abstratos, aumentando a "energia da vontade" (SCHOPENHAUER, 1925, p. 199-200), assim "os motivos são alterados e a vontade não pode se decidir como faria nas mesmas circunstâncias, se o intelecto os apresentasse em seu aspecto verdadeiro" (SCHOPENHAUER, 1925, p. 197). 
Em relação ao "conhecimento íntimo de nós mesmos" que influencia uma ação futura, Salomon Reinach, em uma nota crítica de sua tradução francesa do Ensaio sobre a liberdade da vontade, afirma que

\begin{abstract}
há aí uma idéia profunda que Schopenhauer não desenvolveu, sem dúvida porque reconhece que ela pertence propriamente a Schelling e a Hegel: "a liberdade é a necessidade compreendida" (Hegel) - "todo ser, logo que se torna sujeito, converte a determinação em espontaneidade, a necessidade em liberdade" (Schelling) (SCHOPENHAUER, 1925, p. 195).
\end{abstract}

Não é preciso ir muito longe para constatar a incorreção da crítica de Reinach: no último capítulo do mesmo ensaio, intitulado Meus predecessores, Schopenhauer apresenta uma análise da questão schellinguiana mostrando que a tese da coexistência da liberdade e da necessidade no Idealismo pós-kantiano foi, inconfessadamente, parafraseada de Kant. "Schelling está pois, a respeito disto", diz Schopenhauer, "em relação à Kant na feliz posição de Américo Vespúcio em relação à Colombo: a descoberta feita por outro foi assinada em seu nome" (SCHOPENHUAUER, 1925, p. 162). A paráfrase e a desonestidade de Schelling serão novamente denunciadas em Sobre o fundamento da moral (SCHOPENHAUER, 2001c, p. 95). Portanto, vê-se que em momento algum o filósofo reconhece que a origem da idéia está em Schelling.

À luz destas explicações o fenômeno do arrependimento é entendido não como uma censura pelo que se quis, mas tão somente pelo que se fez - não se dirige ao esse, mas ao operari. Percebe-se que um falso juízo não permitiu a adequação da ação ao querer: a retificação deste juízo é o arrependimento. Enquanto, pois, o arrependimento se dirige ao conhecimento, o remorso (Reue) é a mágoa que advém da consciência da natureza em si do próprio indivíduo, isto é, da inalterabilidade da vontade que é a fonte de sua má ação. Eis a causa do sofrimento experimentado no remorso: no olhar dirigido ao passado se põe diante de si a 
imagem do próprio caráter. Do mesmo modo, é ao caráter do indivíduo que se dirige o julgamento moral, não propriamente aos motivos ou às suas ações ${ }^{11}$.

Isto posto, pode-se compreender o significado da responsabilidade moral no âmbito deste severo determinismo: é sobre esse mesmo caráter, independente das circunstâncias em que as ações foram impelidas pelos motivos, que recai a responsabilidade moral. Porque se tem este caráter e não outro é que a ação executada só poderia ter sido esta e não outra (dados os motivos e as circunstâncias) e cada indivíduo é assim responsável por seus atos, pois outra ação seria impossível - "ele poderia ter sido outro: e naquilo que ele é estão culpa e mérito" (SCHOPENHAUER, 2001c, 96). Eis a verdadeira liberdade moral: nesta relação entre a vontade e o motivo não há qualquer terceiro elemento que, como uma espécie de deus ex machina (seja ele um Imperativo da razão ou uma providência divina), pudesse interferir e determinar a vontade. A liberdade é transferida do fenômeno para o mundo em si. É justamente neste sentido que se pode dizer que a vontade é livre, a saber, em sua configuração numênica (o caráter inteligível é fora do tempo, portanto não determinado por coisa alguma), corolário necessário, diz Schopenhauer, da tese kantiana da coexistência da necessidade empírica e da liberdade transcendental.

- O fundamento da moral

No frontispício da quarta e última parte de O mundo como vontade e representação é apresentada a idéia fundamental sobre a qual Schopenhauer erigirá

\footnotetext{
${ }^{11}$ Schopenhauer também utiliza para remorso o termo mais popular Gewissensbiss (literalmente "mordida na consciência"). Nietzsche, crítico severo do remorso como sintoma da doença da vontade fraca, sentencia (§ 38 das Miscelâneas de opiniões e sentenças): "O remorso [Gewissensbiss] é, como a mordida [Biss] do cachorro numa pedra, uma estupidez".
} 
sua ética: Chegando a conhecer-se a si mesma, a vontade de viver afirma-se; depois se nega. Três atitudes serão então analisadas no decorrer deste texto: a afirmação cega da vontade; a afirmação consciente ou negação incompleta da vontade, ou seja, as ações direcionadas pelo caráter adquirido: as virtudes morais da justiça, bondade e caridade; e a negação da vontade no ascetismo. Em seus dois ensaios sobre a moral (Sobre a liberdade da vontade e Sobre o fundamento da moral) nenhuma palavra é dita a respeito da negação da vontade ou do ascetismo. Qual seria a razão de tal silêncio? A razão é que, como pode ser deduzido de uma afirmação de Sobre o fundamento da moral, "a significação moral de uma ação só pode estar na sua relação com outros. Só com referência a estes é que ela pode ter valor moral ou ser condenável moralmente" (SCHOPENHAUER, 2001c, p. 133). Uma ação moral ou imoral deve assim estar relacionada com uma motivação, seja ela altruísta ou egoísta, o que exclui o ascetismo que, a despeito das ações virtuosas (dirigidas por uma motivação não egoísta), indiferente a qualquer motivo, deve tombar fora de toda consideração sobre a moral - assim como serão também excluídos os pretensos deveres para com nós mesmos de Kant.

Vejamos mais de perto a atitude da afirmação consciente da vontade. Ela pode ser percebida, diz o filósofo,

quando, na sua manifestação [da Vontade], no mundo e na vida, ela vê a sua própria essência representada a si mesma com plena clareza, esta descoberta não para de modo nenhum o seu querer: ela continua todavia a querer esta vida cujo mistério se desvenda assim perante si, já não como no passado, sem se dar conta, e através de um desejo cego, mas com conhecimento, consciência, reflexão [besonnen] (SCHOPENHAUER, s/d-b, p. $375)$.

A Besonnenheit (clareza de consciência ${ }^{12}$, circunspecção ou reflexão), indispensável no autoconhecimento (conseqüentemente para a afirmação consciente ou para a negação do querer), é referida por Schopenhauer tanto ao

\footnotetext{
${ }^{12}$ Klarheit des Bewußtseyns (SCHOPENHAUER, 1982, p. 129).
} 
conhecimento intuitivo quanto ao conhecimento racional: o que pode surpreender à primeira vista diante das investidas negativas do filósofo contra o saber através dos conceitos. Mas o fato é que a razão (o protocolo das ações), por sua capacidade de reflexão e recordação, é um importante instrumento auxiliar no que diz respeito à ação virtuosa e mesmo na negação da vontade:

Uma liberdade que se manifesta assim é o maior privilégio do homem; faltará eternamente ao animal, visto que tem como condição uma reflexão racional [Besonnenheit der Vernunft] capaz de abarcar o conjunto da existência, independentemente da impressão do presente (SCHOPENHAUER, s/d-b, p. 535).

Em Sobre o fundamento da moral Schopenhauer declara, a respeito dos princípios do conhecimento abstrato, que apesar de não serem "de modo nenhum a fonte originária ou o primeiro fundamento da moralidade, são indispensáveis para levar uma vida moral, como sendo o depósito, o reservatório no qual está conservada a disposição nascida da fonte de toda a moralidade" (SCHOPENHAUER, 2001c, p. 144) - torna-se necessário aqui observar que a constatação de que ainda nos âmbitos estéticos e éticos (anteriores ao ascetismo) a importância da Besonnenheit (como auxiliar no autoconhecimento da Vontade) já se faz presente, torna problemática a afirmação de Jair Barboza, segundo a qual "a negação da Vontade no belo ou na compaixão se dá por intuição ou sentimento"; e mesmo a declaração que "por não possuírem razão, os animais não podem negar a Vontade" (BARBOZA, 2000, p. 205) ${ }^{13}$.

Entretanto, o uso desta faculdade da consciência não implica necessariamente numa ação virtuosa: "pode-se pelo contrário", alerta ele, "agir muito racionalmente, portanto refletida, prudente [besonnen], conseqüente, planejada e

\footnotetext{
${ }^{13}$ Ademais, se não pertence aos animais a faculdade da razão, por outro lado não lhes são vedados a intuição e o sentimento, conforme Schopenhauer: o que lhes impediriam pois de alcançar a negação temporária da arte e da moralidade? Por não perceber ainda o hiato que separa a moral do ascetismo, como mostramos, Jair Barboza conclui, a respeito da Besonnenheit: "O filósofo encontra desse jeito o conceito chave para estender a intuição genial à ascética[meu itálico] e, pela negação da Vontade, aparentar estética e ética" (BARBOZA, 2000, p. 206).
} 
metodicamente, seguindo, todavia as máximas as mais egoístas, injustas e mesmo perversas". (SCHOPENHAUER, 2001c, p. 60-1) ${ }^{14}$. Deste modo, deve-se distinguir o interesse próprio (Eigennutz) de uma ação egoísta planejada por meio da reflexão, do egoísmo (Egoismus) propriamente dito, a motivação fundamental tanto no homem quanto no animal - esta deve ser ainda diferenciada do amor próprio (Selbstsucht) que tem uma conotação mais patológica.

"O ar das cortes não é respirável para todos os pulmões", diz aristocraticamente Schopenhauer. Sabemos disto; entretanto, aquele que nas suas atitudes é arrastado pelo seu daimon, sentencia o filósofo - sem atentar que o daimon, na configuração socrática como ficou marcada na filosofia, não lembra em nada a afirmação cega da vontade (trata-se, antes, da comedida voz de Apolo, diria Nietzsche) -, aquele que irrefletida e desenfreadamente busca a satisfação dos desejos advindos daquela disposição natural da vontade, transforma a linha de sua vida num tortuoso caminho em zig-zag, repleto de frustrações e sofrimentos de todos os tipos. Não se tem pois a clara consciência do que se quer e do que se pode e, assim, do que convém a cada um. Seguindo as ordens do desejo cego, o homem dificilmente procura renunciar a alguns bens em nome de outros; dificilmente procura restringir suas ações aos objetos que estão ao seu alcance. E isto porque a Vontade, insaciável, o impede de sequer ponderar sobre o assunto. Deste modo, constata o filósofo, "estendemos as mãos como as crianças, na feira, em direção a tudo o que, à nossa volta, nos apetece" (SCHOPENHAUER, s/d-b, p. 400). Na

\footnotetext{
${ }^{14}$ Schopenhauer afirma que somente após Kant o comportamento racional será identificado com virtude: tal assertiva não leva em conta, evidentemente, o pensamento socrático, no qual tal identificação pode sem dúvida ser notada. Por outro lado, a Besonnenheit pode ser identificada com o caráter adquirido. O que não é adequado (como o faz a tradução da Rés de $O$ mundo como vontade e representação) é traduzir esta expressão por sanguefrio: "É preciso ter chegado aí para manter sempre um perfeito sangue-frio [Besonnenheit]" (SCHOPENHAUER, s/d-b, p. 403). Schopenhauer chega a usar a expressão sangue-frio (Kaltblütigkeit) para se referir ao caráter adquirido, mas somente no Suplemento ao Livro II de $O$ mundo como vontade e representação: "O sangue-frio [Kaltblütigkeit] é a vontade se ocultando, a fim de que o intelecto possa agir" (SCHOPENHAUER, s/d-a, p. 27). Isto posto, não se perde de vista o caráter fisiologicista que diferencia os Suplementos do texto da primeira edição de 1819.
} 
afirmação cega da vontade, o intelecto, através do princípio de individuação, acaba por perceber nas coisas apenas motivos para a satisfação do querer, promovendo, se necessário for, a infelicidade, a destruição das outras individualidades em nome do bem-estar do eu, da egoidade. O egoísmo e a maldade surgem assim como os parceiros da afirmação do querer, geradores da luta, da discórdia, da bellum omnium contra omnes (guerra de todos contra todos) hobbesiana e, conseqüentemente, do sofrimento. Esta atitude ganha uma perfeita simbologia, segundo o filósofo, no mito grego de Proserpina e no mito cristão do pecado original adâmico: a romã no primeiro e a maçã no segundo representariam tão somente os motivos da satisfação carnal (Geschlechtsbefriedigung) ${ }^{15}$. E é na satisfação sexual que se verifica o ponto máximo de afirmação da vontade. Muitas partes do organismo animal funcionam quase à revelia do intelecto; nos órgãos sexuais percebe-se uma submissão completa à vontade e a independência absoluta da inteligência.

Para evitar o infortúnio em que se transforma a vida fundada neste tipo de atitude, diz ele:

\begin{abstract}
É preciso que as experiências venham ensinar-nos o que queremos, o que podemos: até essa altura ignoramo-lo, não temos caráter; e é preciso mais do que uma vez que rudes fracassos venham relançar-nos na nossa verdadeira via. - Enfim, aprendemo-lo, e chegamos a ter aquilo que o mundo chama caráter, isto é o caráter adquirido. Aí existe, portanto, apenas um conhecimento, o mais perfeito possível da nossa própria individualidade: é uma noção abstrata, e por conseqüência clara das qualidades imutáveis do nosso caráter empírico, do grau e da direção das nossas forças (tanto espirituais como corporais), em suma, do forte e do fraco em toda a nossa individualidade (SCHOPENHAUER, s/d-b, p. 402).
\end{abstract}

A afirmação da vontade agora se faz com uma clareza de consciência muito maior. Nesta economia da vontade, nesta resignação consciente aos limites de nossa capacidade e à inevitabilidade do destino implacável, vemos apascentado o frenesi do querer cego e podemos cultivar, aconselha Schopenhauer, as nossas

\footnotetext{
${ }^{15}$ A figura do Cristo representará a atitude ascética da negação da vontade, da vida.
} 
disposições naturais mais notáveis. As nossas fraquezas não nos atormentarão mais. Enfim, não se deseja mais estar no lugar de um outro, ter as suas qualidades ou mesmo ser um outro. Trata-se da mais absoluta resignação, da aceitação passiva ou désabusement (PHILONENKO, 1999, p. 219) diante do fato, de não desejar nada para além das circunstâncias. Não existe maior consolo, dirá Schopenhauer, que o fatalismo: "não há fonte de consolação mais segura do que ver com uma perfeita evidência a necessidade do que acontece" (SCHOPENHAUER, s/d-b, p. 404). "Eis porque", explica o autor de $O$ mundo,

\begin{abstract}
vemos muitas pessoas atingidas por algum destes males que não passam, tais como uma deformação, pobreza, baixa condição, fealdade, morada insalubre, acomodarem-se a eles, tornarem-se indiferentes, não os sentir mais do que uma ferida cicatrizada, simplesmente porque sabem que neles e à volta deles as coisas estão organizadas de modo a não deixar oportunidade para nenhuma mudança; no entanto, aqueles que são mais felizes não compreendem que se suporte um tal estado (SCHOPENHAUER, s/d-b, p. 405).
\end{abstract}

A afirmação consciente da vontade (ou caráter adquirido) foi já interpretada a partir de uma equiparação com a idéia do amor fati nietzschiano. Alexis Philonenko em seu Schopenhauer, une philosophie de la tragédie intitula seu capítulo sobre o caráter adquirido simplesmente como amor fati (§ 49): não se trataria, diz ele a respeito deste autoconhecimento da Vontade, de uma transformação de seu impulso cego, mas de um esclarecimento. A mesma posição é compartilhada por Oswaldo Giacóia $^{16}$. Em seu artigo Schopenhauer et la mortrenaissance, publicado na coletânia de Paul Droit, Presences de Schopenhauer, Michel Hulin vai mais longe ao perceber no caráter adquirido uma "antecipação da idéia de Super-homem" (In: DROIT, 1989, p. 104). Uma passagem de A gaia ciência poderia mesmo levar a crer que estamos diante de uma paráfrase de Schopenhauer (mas que não se refere diretamente ao Amor fati):

\footnotetext{
${ }^{16}$ Em palestra proferida no segundo Colóquio Schopenhauer realizado em Salvador no mês de outubro de 2003.
} 
"Dar estilo" a seu caráter - uma arte grande e rara! É praticada por quem avista tudo o que sua natureza tem de forças e fraquezas e o ajusta a um plano artístico, até que cada uma delas aparece como arte e razão, e também a fraqueza delicia o olhar. Aqui foi acrescentada uma grande massa de segunda natureza, ali foi removido um bocado de primeira natureza (NIETZSCHE, 2001, p. 195).

Uma suspeita pode, no entanto, ser levantada a respeito desta aproximação. Ao apresentar, no âmbito da moral, a atitude por excelência que representa a afirmação consciente da vontade, Schopenhauer não deixa dúvidas: trata-se da compaixão - a justiça e a caridade são dela derivadas. Tem-se já aí, na resignação da ação compassiva, uma negação da vontade, ainda que em escala menor; em suma, trata-se de um dizer Não diante da visão do aspecto trágico da existência - Nietzsche, por outro lado, com o Amor fati, parece ter a pretensão de "aprender a ver como belo aquilo que é necessário nas coisas", afirma, no início do quarto livro de A gaia ciência; e continua: "assim me tornarei um daqueles que fazem belas as coisas. Amor fati: seja este, doravante, o meu amor! [...] Que a minha única negação seja desviar o olhar! E, tudo somado e em suma: quero ser, algum dia, apenas alguém que diz Sim" (NIETZSCHE, 2001, p. 187-8). Por outro lado, diria Schopenhauer, assim como no sentimento do belo, na compaixão o Véu de Maya fora rasgado apenas em parte, restando ainda resquícios da afirmação da vontade, pois a ação se dá ainda guiada por motivos (ainda que estes sejam o bem alheio). Deveria então ser explicado como é possível que a mesma compaixão combatida com veemência por Nietzsche desde seu primeiro escrito apareça sub-repticiamente agora sob a dionisíaca imagem afirmadora do Übermensch (caso o relacionemos ao caráter adquirido de Schopenhauer, como nos exemplos citados acima).

De fato, tem-se já na afirmação consciente da vontade um anestésico para os sofrimentos da vida, um calmante para a vontade, que não deixa de trazer um certo contentamento (Zufriedenheit). Pode-se dizer certamente que foi alcançada a ataraxia grega. Mas que se tenha em mente aqui a paz de espírito estóica e, em 
certa medida, a epicurista (a ataraxia da negação da vontade terá um outro caráter) ou, no limite, a autarquia cínica.

Dadas estas descrições do fundamento metafísico das ações humanas, pergunta-se agora qual delas poderia trazer inexoravelmente a marca da moralidade. Em suma, trata-se do questionamento sobre o fundamento da moral feito pela Academia dinamarquesa ao qual Schopenhauer empreenderá uma resposta (malograda, segundo o julgamento da Academia) em 1840. A uma exposição empírica neste ensaio, o filósofo faz seguir, como adendo, uma pequena exposição do fundamento metafísico da moral: uma opus superogationis (obra que ultrapassa a exigência).

Como foi dito, a negação total da vontade do ascetismo não entra em jogo, pois a moralidade só se efetiva no âmbito da intersubjetividade, quando ainda se pode falar de uma certa motivação moral, o que não é o caso do asceta, para quem não faz sentido o agir por motivos. Por outro lado, a única motivação moral reconhecida pelo filósofo é aquela despida de qualquer egoísmo, ou seja, nenhuma ação que tenha como motivo (direta ou indiretamente) o bem-estar do próprio sujeito pode ter uma valoração moral positiva. Deste modo, toda ação levada a cabo pela ameaça de castigo ou promessa de recompensa é egoísta. Dificilmente uma afirmação cega da vontade conduziria, como se viu, a tal disposição moral.

A consideração schopenhaueriana sobre o fundamento da moral deve começar por uma análise da ética kantiana "porque a grande reforma moral de Kant deu a esta ciência uma fundamentação que tinha reais vantagens diante das anteriores", reconhece Schopenhauer, "e, em parte, porque ainda é a última mais significativa que aconteceu na ética" (SCHOPENHAUER, 2001c, p. 15) ${ }^{17}$.

\footnotetext{
${ }^{17}$ Em seus Fragmentos para a história da filosofia, dos Parerga e Paralipomena, Schopenhauer é mais incisivo ao declarar que entre Kant e ele não se escrevera uma palavra sequer que pudesse ser tomada como verdadeira filosofia.
} 
Conquanto tenha Kant deslocado a fundamentação moral do fenômeno para o mundo em si (uma das três jóias da coroa kantiana, dirá Schopenhauer), não estará livre das duras críticas schopenhauerianas em relação ao imperativo categórico, este "confortável encosto" (SCHOPENHAUER, 2001c, p. 15) sobre o qual repousava a Ética de sua época. A senilidade, diz ele, seria a causa dos problemas encontrados na Crítica da razão prática e na segunda edição da Crítica da razão pura.

O proton pseudós (primeiro passo em falso) de Kant seria a petitio principii (petição de princípio) da imposição de leis morais, que deveriam regular as ações, sem uma prévia demonstração de sua validade. No "tu deves" da lei moral se esconde sub-repticiamente a moral teológica do decálogo mosaico, sendo pois o Imperativo hipotético e não categórico na medida em que está condicionado a uma promessa de recompensa ou ameaça de castigo - como toda ação guiada pela idéia do dever absoluto, uma contradictio in adjecto. Na sua redução do valor moral às ações por dever, a ética de Kant se ampara no medo escravo dos demônios, o Imperativo seria o Vitzliputzli (ou Huitzilopotchli, divindade mexicana da guerra):

O valor do caráter só se institui quando alguém sem simpatia no coração, frio e indiferente ao sofrimento de outrem, realiza boas ações não nascidas, na verdade, da solidariedade humana, mas apenas por causa do enfadonho dever [...] Tem de ser comandada! Que moral de escravos! (SCHOPENHAUER, 2001c, p. 40).

Schopenhauer procurar mostrar, com isto, que o Soberano Bem vem substituir a promessa de recompensa divina da moral teológica, denunciando a pretensão da ética de Kant de ser fundada sobre o desinteresse: antes, resgata ela o eudemonismo supostamente rejeitado da filosofia antiga:

Isto na realidade nada mais é do que uma moral que visa a felicidade, apoiada conseqüentemente no interesse próprio ou eudemonismo, que Kant solenemente expulsou como heterônoma pela porta de entrada de seu sistema e que de novo se esgueirou sob o nome de Soberano Bem pela porta dos fundos (SCHOPENHAUER, 2001c, p. 28). 
Neste ponto, comprovando a eficácia da crítica schopenhaueriana, podemos verificar que a crítica de Nietzsche ao imperativo de Kant é semelhante à de Schopenhauer:

\begin{abstract}
A escravidão é, no sentido mais grosseiro ou no mais sutil, o meio indispensável também para a disciplina e cultivo espiritual. Considere-se toda moralidade sob esse aspecto: [...] "Deves obedecer seja a quem for, e por muito tempo: senão perecerás, e perderás a derradeira estima por ti mesmo" - esse me parece ser o imperativo categórico da natureza, o qual certamente não é "categórico", como dele exige o velho Kant (daí o "senão") (NIETZSCHE, 1992a, p. 89).
\end{abstract}

Eis o passe de mágica (Kunststück) apresentado pela filosofia prática de Kant: "depois que ele virou a coisa de ponta-cabeça, ninguém, nem mesmo ele, a reconheceu como sendo aquilo que ela era, a velha e bem conhecida moral teológica" (SCHOPENHAUER, 2001c, p. 30). Este auto-engano inconsciente de Kant em que a moral teológica é a premissa tácita de sua argumentação, Schopenhauer compara com o homem que corteja uma mulher num baile de máscara durante toda a noite para, no final, constatar que se tratava de sua própria esposa. É mister pois traçar a genealogia dos impulsos inconscientes que revela a pregação kantiana do imperativo categórico, como faz Schopenhauer também no apêndice Crítica da filosofia kantiana. Do mesmo modo, Nietzsche procura apontar para a pré-história dos impulsos e inclinações que antecede a consciência moral de Kant:

E agora não me venha falar de imperativo categórico, meu amigo! - essa expressão me faz cócegas no ouvido e eu tenho que rir, mesmo em sua tão séria presença: lembra-me o velho Kant, que, como punição por ter obtido furtivamente a "coisa em si" - também algo ridículo -, foi furtivamente tomado pelo "imperativo categórico", e com ele no coração extraviou-se de volta para "Deus", "alma", "liberdade" e "imortalidade", semelhante a uma raposa que se extravia de volta para a jaula (NIETZSCHE, 2001, p. 223).

Além da forma imperativa moldada pela moral teológica a ética kantiana cometeria também um outro grave pecado, conforme a denúncia de Schopenhauer: 
a falta de efetividade. A lei moral não pode ter uma fundamentação empírica, ou seja, não pode ser fundada na experiência interna (como um fato da consciência) tampouco na externa; nem no subjetivo (antropológico) nem no objetivo. Por este motivo ela só pode ser conhecida a priori e nunca a posteriori. No entanto, questiona Schopenhauer, se o apriorismo da filosofia teórica (formas do entendimento) se aplica tão somente ao fenômeno, o apriorismo da lei moral não poderia igualmente se relacionar com o em si das coisas, como pretende Kant - outra contradição detectada seria aquela existente entre $A$ fundamentação da metafísica dos costumes de Kant, na qual é rejeitada qualquer fundamentação empírica da lei, e a Crítica da razão pura, em que a mesma lei é tomada como um fato da razão ${ }^{18}$. Todavia, a lei moral deve encontrar seu fundamento na forma e não no conteúdo das ações, constituindo-se de meros conceitos abstratos da razão sem qualquer relação com a realidade empírica: numa palavra, são "puras cascas sem caroço", diz Schopenhauer:

Reflita-se sobre o quanto isto quer dizer: a consciência humana tanto quanto todo o mundo exterior junto com toda a experiência e todos os fatos é tirada de baixo de nossos pés. Não temos nada em cima do que ficar. Mas onde devemos nos apoiar? Em alguns conceitos bem abstratos, completamente sem conteúdo, que, por isso mesmo, pairam totalmente no ar. É a partir deles, mais precisamente da mera forma de sua ligação nos juízos, que deve originar-se uma lei, que deve valer com a assim chamada necessidade absoluta, tendo a força de pôr rédea e bridão ao ímpeto do desejo, à tempestade da paixão, ao tamanho gigantesco do egoísmo. É o que queremos ver (SCHOPENHAUER, 2001c, p. 35-6).

Semelhante irritação é externada também pelo filósofo diante da argumentação kantiana contra o suicídio, tomada como mesquinha e não merecedora de resposta: "temos de rir quando pensamos que tais reflexões teriam

\footnotetext{
${ }^{18}$ A tese da razão enquanto legisladora absoluta, neste último escrito, que pode, com suas leis, determinar a vontade imediatamente, teria levado os pós-kantianos - entre eles Hegel, o charlatão sem-espírito (Geistlos) - à idéia da intuição intelectual que conhece imediatamente o supra-sensível - a Cucolândia nas nuvens, diz Schopenhauer (SCHOPENHAUER, 2001c, p. 57). Se existisse de fato este acordo da razão com os objetos da metafísica, "seria impossível que se encontrasse na Terra um grande número de religiões fundamentalmente diferentes e um número ainda maior de sistemas filosóficos fundamentalmente diferentes" (SCHOPENHAUER, 2001c, p. 62).
} 
de arrancar o punhal das mãos de Catão, de Cleópatra, de Cócio Nerva ou de Arria de Paetos" (SCHOPENHAUER, 2001c, p. 32). Nem mesmo a utilização feita por Kant de expressões jurídicas latinas na exposição da consciência moral (o fórum da razão) pode ser apropriada "para traduzir os sentimentos mais íntimos do coração humano" (SCHOPENHAUER, 2001c, p. 88). A razão para tal procedimento em Kant seria a velada presença da psicologia racional, a distinção entre corpo material e alma imortal (ou nos anjinhos da Escolástica, ironiza Schopenhauer) - cuja principal característica seria a da racionalidade - que ele recusara na filosofia tradicional e cuja retomada é agora colocada à luz pela análise genealógica de Schopenhauer. A lei moral seria válida então apenas para os seres racionais: uma classe de seres hipostasiada e distinta da classe dos seres humanos. Em contraposição a isto Schopenhauer afirma que o conhecimento no homem é secundário, sendo a Vontade primária e essencial. Ademais, a moral tem que estar relacionada com a ação efetiva do homem "e não com castelos de cartas apriorísticos", com uma "teia de aranha de conceitos" (SCHOPENHAUER, 2001c, p. 52), deve repousar na apreensão intuitiva, na realidade das coisas, exigindo pouca reflexão, abstração e combinação. Uma ação executada por uma mera máxima, sem qualquer motivação exterior, além do mais é egoísta: só a intenção, dirigida por algo externo, poderia ser levada em conta como critério de valoração moral. A motivação deve pois ser empírica; nenhum conceito abstrato tem o poder de "pôr em movimento pelo menos os homens: de outros seres racionais não posso falar", sentencia o filósofo (SCHOPENHAUER, 2001c, p. 52). Por conseguinte, a busca filosófica pelo fundamento da moral deve assentar na própria natureza humana assim como rejeitar toda maquinaria de um outro mundo e ser "independente de todas as explicações místicas, dogmas religiosos e hipóstases transcendentes, e exige ver esta 
elucidação demonstrada, quer na experiência externa, quer na interna" (SCHOPENHAUER, 2001c, p. 129).

Isto posto, somos levados a concluir que é ainda o egoísmo o fundamento da lei moral kantiana, pois é sobre o poder querer do sujeito que se ancora o Imperativo categórico ${ }^{19}$, isto é, a suposta lei autoriza a ação em que o sujeito recebe, em troca de sua boa ação, igual tratamento pela parte passiva: vale aqui a regra da reciprocidade, a saber, devo me colocar no lugar do outro e verificar se quero que ele me faça também aquilo que intento fazer em relação a ele. Em suma, é sempre o bem-estar do sujeito da ação que a comanda, numa palavra: o egoísmo. Aquela palavra de ordem, diz Schopenhauer, poderia ser adequada à Política, a um discurso sobre o Estado, nunca à moral. À guisa de conclusão, nesta crítica a Kant Schopenhauer apresenta a filosofia de Fichte como um espelho de aumento dos erros da ética kantiana, uma caricatura de Kant, o que poderia ser explicado pelo fato de ser ele "um homem a quem o ensinar não deixou tempo para aprender" (SCHOPENHAUER, 2001c, p. 103).

Para se chegar ao verdadeiro fundamento de toda ação moral, deve-se antes de tudo distinguir claramente o princípio do fundamento moral. Esta distinção, segundo Schopenhauer, não fora ainda levada a cabo na história da ética. O princípio moral é a expressão concisa elaborada e fixada pelo conhecimento abstrato que deve guiar um modo de agir prescrito, valorável moralmente: é o "hó, ti" (que) da virtude. O fundamento, por outro lado, é o "dióti" (porque), a razão de tal obrigação e do valor moral conferido à ação, que pode ser encontrado na natureza humana ou no mundo exterior. O erro de todos os filósofos estaria no fato de

\footnotetext{
19 "Age somente segundo a máxima que possas ao mesmo tempo querer que valha universalmente para todo ser racional". Neste sentido Nietzsche se coloca ao lado de Kant a propósito disto que, de acordo com o próprio Nietzsche, é considerado por Schopenhauer como uma banalidade, uma tolice kantiana (Aurora, § 132): deve-se permanecer insensível diante do sofrimento alheio! "Admire antes o seu egoísmo nisso", afirma ele, em A gaia ciência, referindo-se, contudo, ao próprio imperativo categórico como um egoísmo cego, estreito e modesto. (NIETZSCHE, 2001, p. 224)
} 
confundirem o "hó, ti" com o "dióti", de tomarem, consciente ou inconscientemente, o princípio pelo fundamento. Qual poderia ser pois o princípio, aquela proposição singular que concisamente reuniria todos os princípios reguladores das ações morais já pensados até então (inclusive o Imperativo kantiano)? Resposta de Schopenhauer:

Quero pois conduzir aquele "hó, ti" - que é o princípio, a proposição fundamental sobre cujo conteúdo todos os éticos estão de acordo, por mais de versas maneiras com que o vistam - à expressão que tomo pela mais fácil e mais pura de todas: "neminen laede, imo omines, quantum potes, iuva" [não faças mal a ninguém, mas antes ajuda a todos que puderes!]. Esta é propriamente a frase que todos os doutrinadores de moral esforçam-se por fundamentar, o resultado comum de suas tão variadas deduções: é o "hó, ti" para o qual se busca ainda sempre o "dióti", a conseqüência para a qual se exige a razão, portanto o próprio "datum", do qual o "quaesitum" é o problema de toda a ética e também da presente pergunta premiada (SCHOPENHAUER, 2001c, p. 44).

Feita assim a distinção entre o princípio e o fundamento - doutro modo cairíamos em uma ética prescritiva, como a kantiana - pode ser reiniciada a busca deste último, a pedra filosofal (Stein der Wesen) da ética, escondida há séculos: "Contrapor ao egoísmo, e ainda por cima à maldade, um campeão adulto e superior a elas - este é o problema de toda ética" (SCHOPENHAUER, 2001c, p. 72).

Antes de mais nada, é preciso levar em conta a posição cética, na qual a moral seria apenas um artefato, um instrumento inventado para a domesticação do maldoso gênero humano, pois não poderia ser encontrado o seu fundamento na natureza ou no homem. Segundo a citação de Sexto Empírico feita por Schopenhauer: "não há por natureza nem bem nem mal, mas é a mente dos homens que os diferenciou" (SCHOPENHAUER, 2001c, p. 109). Reconhece-se que uma parte considerável das ações justas e caritativas repousa em uma intenção egoísta como a esperança de retribuição, o temor do policiamento do Estado, ou mesmo a manutenção do bom nome, mas por outro lado, afirma Schopenhauer, não restam dúvidas sobre a existência efetiva de caridade desinteressada e justiça 
espontânea, ainda que em raríssimas exceções: "há de fato pessoas verdadeiramente honestas, como há também realmente trevos de quatro folhas" (SCHOPENHAUER, 2001c, 114-5). Se fosse negado tal fato a moral seria simplesmente esvaziada de todo o seu conteúdo, tornando-se uma ciência sem objeto semelhante à astrologia ou à alquimia. Conquanto não deva ser simplesmente desconsiderada a visão cética, pois modera a expectativa quanto à disposição moral, pode-se invocar uma contraprova decisiva: o fato da consciência moral (Gewissen). Esta, no entanto, não pode ser confundida com a mera conscientia espuria que nada mais é que o medo da punição por algo que se fez. Numa antecipação a Freud e a idéia do superego como uma internalização das regulações externas da cultura, afirma Schopenhauer a respeito do remorso (Reue):

\begin{abstract}
A violação de preceitos externos, arbitrários e até banais atormenta a muitos com reprovações internas, a modo de uma consciência [...] Muitos ficariam admirados se vissem do que se compõe sua consciência moral, que lhes aparece tão imponente: aproximadamente um quinto de temor aos homens, um quinto de temor aos deuses, um quinto de preconceito, um quinto de vaidade e um quinto de costume (SCHOPENHAUER, 2001c, p. 115-6).
\end{abstract}

Estas punições internas podem atingir um nível insuportável que em alguns casos leva ao suicídio, conclui o filósofo.

$\mathrm{Na}$ busca desta ação moral genuína, que se segue da afirmação consciente da vontade, como foi visto, convém analisar também o seu oposto, aquela guiada pelo egoísmo ou pela maldade, conseqüência necessária do impulso natural da afirmação cega da vontade - procedimento que distanciaria a Ética de Schopenhauer das anteriores e a aproximaria de Dante, afirma o filósofo, "que, primeiro, conduz ao inferno" (SCHOPENHAUER, 2001c, p. 127) ${ }^{20}$. Assim como o

\footnotetext{
20 "O mundo constitui o inferno, e os homens formam em parte os atormentados e noutra os demônios", sentencia ele nos Parerga e paralipomena (SCHOPENHAUER, 1980, p. 223).
} 
poeta italiano, Schopenhauer apresenta antes o inferno da condição humana e somente depois apresentará o paraíso da salvação ética.

O egoísmo ilimitado, a luta pela existência e bem-estar, é a motivação fundamental em quase todas as atitudes. O homem quer incondicionalmente a conservação da própria existência e a obtenção da máxima quantidade de prazer que dela pode ser extraída, não medindo esforços para afastar qualquer obstáculo, preferindo a destruição do mundo à sua própria. Quer pois, para isso, tudo a seu favor, tudo em seu domínio, "quer, o quanto possível", afirma Schopenhauer indicando que a vontade de viver (Wille zum Leben) é originária, sendo a vontade de poder (Wille zur Macht) secundária e subordinada -, "desfrutar tudo, ter tudo. Porém, como isto é impossível, quer, pelo menos, dominar tudo" (SCHOPENHAUER, 2001c, p. 121).

É na senda hobbesiana da afirmação do querer (o homem é o lobo do homem), conflito e sofrimento, que vemos à nossa volta a existência se transfigurar no pior de todos os pesadelos: ela pode ser encarada como uma galeria de caricaturas (esteticamente), um hospício (cientificamente) ou um covil de ladrões (moralmente). Para o egocentrismo do indivíduo o mundo visto pelo olhar da representação é apenas um instrumento em potencial para a satisfação de sua própria vontade. Apenas o Estado (a obra-prima do egoísmo racional), em escala maior, e a cordialidade, em escala menor, podem pôr rédeas no ímpeto do desejo:

É preciso ler histórias criminais e descrições de situações anárquicas para saber o que é propriamente o ser humano no aspecto moral. É preciso ver os milhares que se acotovelam uns aos outros num transitar pacífico, diante de nossos olhos, como se fossem tigres e lobos cujas mandíbulas estivessem seguras por forte focinheira. Por isso, quando se pensa a violência estatal como suprimida, quer dizer, a focinheira como tendo sido retirada, toda pessoa inteligente recua diante do espetáculo que é de se esperar (SCHOPENHAUER, 2001c, p. 118). 
Daí a hipérbole formulada por Schopenhauer (alguns homens seriam capazes de assassinar um outro só para engraxar suas botas com a gordura dele) sobre a qual considera escrupuloso pensar se se trata realmente de uma hipérbole. A maldade (Bosheit) levada ao extremo transforma-se em crueldade (Grausamkeit) (ambas têm o sofrimento do outro como fim em si); por outro lado a inveja e a alegria maligna (felicitar-se pela infelicidade do outro) são o aspecto teórico daquelas ${ }^{21}$.

O egoísmo é a contraparte da justiça ao passo que a maldade - ou malevolência (Übelwollen), ódio (Gehässigkeit) - é o vício que se contrapõe à virtude da caridade (Menschenliebe). O primeiro vício pode ser considerado ainda humano, diz Schopenhauer, o segundo é diabólico ${ }^{22}$.

Diante de tal realidade só nos restaria talvez a misantropia, como prescreve Schopenhauer em sua Parábola dos porcos-espinhos (SCHOPENHAUER, 1968, vol. V, p. 765) e como de fato vivera boa parte de sua vida. No entanto, cabe a ele ainda, como teórico da moral, elaborar o discurso filosófico sobre aquelas raras exceções em que a virtude aponta neste mundo do infortúnio. Tendo em vista o que foi colocado, a respeito das motivações antimorais, é-nos dada a certeza de que a única ação dotada de valor moral positivo é aquela despida de qualquer motivação egoísta, por mais longínqua e indireta que ela seja, isto é, a atitude que nos conduzirá ao fundamento da moral só pode ser aquela em que todo interesse próprio (o bem-estar ou mal-estar do sujeito da ação) foi colocado de lado: somente

\footnotetext{
${ }^{21}$ Para Nietzsche o riso tem origem na alegria maligna - mas com boa consciência, diz, em A gaia ciência (NIETZSCHE, 2001, p. 172).

${ }^{22}$ A toda observação sobre a maldade humana Schopenhauer acrescenta abundantes considerações contra o maltrato dos animais, contra o "chicoteamento até a morte diante de carroças inamovíveis" (SCHOPENHAUER, 2001c, p. 77). Esta peculiaridade, que Nietzsche encontra também em Voltaire e Wagner, será tomada por ele como o travestimento do "ódio a certas coisas e pessoas em misericórdia para com os animais" (NIETZSCHE, 2001, p. 125). Curioso é notar que apesar daquela defesa apaixonada, Schopenhauer não abraça a causa da dieta vegetariana como a solução para a matança de animais, pois "sem nutrição animal, o gênero humano no norte nem ao menos pode fazer o animal trabalhar para ele, e só o excesso de um esforço imposto torna-se crueldade" (SCHOPENHAUER, 2001c, p. 183).
} 
as ações genuinamente desinteressadas são morais. E a virtude por excelência que representará tal desinteresse é a compaixão (Mitleid), o fundamento da moral as virtudes da justiça (representada pelo neminem laede do princípio) e da caridade (omnes quantum potes, iuva) serão dela derivadas ${ }^{23}$. De fato, na ação altruísta o outro não é tomado como um objeto, como um mero motivo para a satisfação do querer próprio, pelo contrário, percebe-se que a essência deste é a mesma do sujeito (a Vontade) e nesta identificação - este ato misterioso (mysteriös), diz Schopenhauer - as dores dele são sentidas como suas, levando a egoidade a um completo esquecimento de si mesma ${ }^{24}$; o motivo da ação será pois unicamente o bem-estar ou mal-estar de outra pessoa: eis o que se deve compreender sob a idéia do sentir-com da Mit-leid, da com-passio, fenômeno que efetivamente está diante de nós, é um fato da consciência, e deve ser levado em conta na investigação da moral.

Vemos deste modo, neste grande mistério da Ética, "a supressão da parede divisória que, segundo a luz natural (como os antigos teólogos chamam a razão), separa inteiramente um ser de outro ser, e vemos o não-eu tornar-se numa certa medida o eu" (SCHOPENHAUER, 2001c, p. 136). Se na virtude da justiça a identificação com o sofrimento alheio impede a provocação de qualquer dano, na caridade se é impelido a uma ajuda ativa. A primeira pode ser considerada uma virtude por excelência masculina e a segunda feminina, diz Schopenhauer, mostrando também que ambas são empíricas, destituídas de qualquer significado místico: são mesmo anteriores a qualquer religião positiva e ao Estado - a justiça aparece como a virtude do Velho Testamento e a caridade a do Novo.

\footnotetext{
${ }^{23}$ Esta é uma novidade apresentada pelo ensaio Sobre o fundamento da moral, pois em $O$ mundo como vontade e representação as ações são classificadas hierarquicamente, da ação justa ao ascetismo passando pela caridade e pela compaixão, pois ali a questão era analisada sob a perspectiva da negação da vontade, sendo as virtudes tomadas juntamente com o ascetismo a partir da força da intuição capaz de subverter o princípio de individuação, o véu de Maya.

${ }^{24}$ Tat-tvam-asi (isto és tu) diz a expressão védica utilizada por Schopenhauer.
} 
O conceito de direito (e toda atividade estatal) como o mero impedimento de um ato injusto é negativo, sendo a injustiça, pois, positiva. O Estado não tem assim a função de moralizar o indivíduo, mas apenas resguardar os direitos da vítima de não sofrer uma ação injusta. Na autodefesa a violência e a astúcia (incluindo o direito de mentir) não são reprováveis moralmente. A diferença entre os caracteres pode ser constatada na diferença das ações que são governadas em geral ou por motivos caritativos ou egoístas.

Isto posto, pode-se então divisar três motivações fundamentais que movem todas as ações humanas:

a) EGOÍSMO: O fim visado é o bem próprio;

b) MALDADE (a crueldade é o seu extremo): Visa-se o sofrimento alheio;

c) COMPAIXÃO: Tem-se como finalidade o bem alheio.

Seguindo a definição traçada por Schopenhauer do critério do valor moral fundado no desinteresse, em que o motivo deve ser o bem-estar ou mal-estar do outro, esbarramos num problema, prontamente percebido por ele, a saber, a maldade é, a partir deste critério, tão desinteressada quanto a compaixão, não guiada pelo bem-estar do sujeito, pois tem como fim último tão somente a dor alheia. Schopenhauer contenta-se neste sentido em afirmar que a maldade é o oposto da ação moral de que se trata, que é condenável, apresentando duas características que marcariam a diferença entre ambas: em primeiro lugar uma ação moral traz certo contentamento íntimo e um aplauso da consciência (Beifall des Gewissens), enquanto a maldade experimenta uma auto-apreciação contrária. Em segundo lugar, ainda que de forma secundária e acidental (sekundäres und akzidentelles), tem-se como conseqüência da primeira o "aplauso e o respeito das testemunhas", ao passo que, na maldade, se tem o contrário (SCHOPENHAUER, 2001c, p. 131). Ora, a partir do critério adotado por Schopenhauer para uma genuína ação moral, estes 
dois diferenciadores se tornam não só desimportantes mas completamente invalidados, pois a motivação moral não pode estar fundada no contentamento ou em qualquer bem relativo ao sujeito que a executa, muito menos no reconhecimento externo, pois se trataria de interesse e, portanto, egoísmo.

Seguem-se daí dois espinhosos problemas (estes não percebidos pelo filósofo): Schopenhauer apresentará, sub-repticiamente, como marca diferenciadora da compaixão em relação à maldade o fato de que a primeira visa o bem alheio e a segunda a dor alheia. Um adendo necessitaria pois ser acrescentado anteriormente àquele critério da moralidade, o que não foi feito: não se trata apenas da ação desinteressada, não basta que o agente não leve em conta o seu bem-estar, mas a ação moral deve ter como fim unicamente o bem do outro.

Afirmar que a compaixão visa o bem alheio significa que a partir da participação no sofrimento do outro se busca o impedimento (justiça) e a supressão (caridade) deste sofrimento. Por outro lado, o seu bem-estar propriamente não promove qualquer estímulo daquela identificação pressuposta para o fenômeno da compaixão, mas, antes, deixa-nos indiferentes. Isto se explica pelo fato de que

a dor, o sofrer, de que faz parte toda falta, carência e necessidade e mesmo todo desejo é o positivo, aquilo que é sentido imediatamente. Ao contrário, a natureza do contentamento, do prazer, da felicidade, consiste só no fato de que uma carência foi suprimida, uma dor aquietada. Estas agem portanto negativamente [...] Também nosso sofrer, no qual tem de ser incluída toda carência, necessidade, desejo e mesmo tédio, estimula também, até para nós mesmos, nossa atividade, enquanto um estado de contentamento e de felicidade nos deixa inativos e em sossego preguiçoso (SCHOPENHAUER, 2001c, p. 138-9).

É pois o sofrimento o único estímulo para o misterioso fenômeno da compaixão, capaz de promover aquela atividade que levará o sujeito a descerrar o véu de Maya e perceber o outro sem o intermédio do principium individuationis. Elaborando a questão de forma ilustrativa, poderíamos afirmar que na atitude destruidora do egoísmo (ou diante da felicidade instaurada do outro) nadamos a 
favor da correnteza, por assim dizer, dado que nosso organismo é um maquinário criado pela Vontade para servi-la, estamos no reino da afirmação do querer: seguimos assim o curso normal das coisas, deixamo-nos levar passivamente pelo sentido natural da correnteza. No entanto, quando esta ordem natural é subvertida e vemos o organismo funcionar à revelia daquela força criadora, nadamos contra a correnteza: de fato, sabemos o quanto de atividade, de penoso esforço é necessário para engendrar e sustentar tal subversão contra a Vontade ${ }^{25}$. A compaixão - que aparentemente deixa-se entender como uma passio, uma passividade, um sofrercom - é pois, pelo que se vê, atividade plena. O contentamento leva, por outro lado ao quietismo, à passividade: o que se torna em certa medida perigoso, pois, diz ele, "a visão daquele que é feliz e sente prazer pode até mesmo excitar muito ligeiramente nossa inveja, já que existe em todo homem a disposição para ela e já que ela encontrou seu lugar de destaque entre as potências antimorais" (SCHOPENHAUER, 2001c, 139).

Daí decorre a segunda problemática implícita na análise schopenhaueriana da compaixão que pode assim ser formulada, em forma de um paradoxo: o objetivo final que conduz à compaixão e àquela atividade que tornará o indivíduo um sujeito puro do conhecimento capaz de agir virtuosamente, a saber, o bem-estar e contentamento do outro, é, por outro lado, justamente aquilo que os afasta, que levará o sujeito a considerar o outro novamente como uma representação, como um objeto, podendo ser estimulada a inveja e, em caso extremo, até a maldade e a crueldade. Para se perceber a extensão da problemática, digamos que somos mesmo autorizados a concluir (por uma Reductio ad absurdum) que a maldade tem lá o seu valor moral, pois que ela visa o sofrimento alheio e também a sua

\footnotetext{
25 "A própria vida é um mar cheio de escolhos e redemoinhos" (SCHOPENHUAER, s/d-b, p. 413). Talvez fosse oportuno lembrar aqui que a própria obra de Schopenhauer já foi representada por esta ilustração, conforme se vê em Denker gegen den Strom (Pensador contra a correnteza) de Arthur Hübscher (HÜBSCHER, 1982).
} 
manutenção (ao contrário da caridade, que intenta a supressão deste): não é este mesmo sofrimento que promove a tão buscada identidade metafísica exigida na moralidade? Uma solução possível seria admitir que o que me impele à compaixão, à justiça ou à caridade, adviria de um sentimento obscuro, uma reminiscência ou uma saudade de um contentamento efetivo e positivo experimentado em relação ao bem-estar do outro, o que conduz à idéia de que o negativo na vida seria, na verdade, a carência (e conseqüentemente o sofrimento), sendo o contentamento, por sua vez, o originário e positivo (capaz assim de produzir a atividade) ${ }^{26}$ : o que Schopenhauer não poderia aceitar, pois coloca em xeque a sua visão de mundo pintada com as cores negras do pessimismo. Pelo contrário, afirma o filósofo, podemos "contentarmo-nos com a felicidade, o bem-estar e o prazer de um outro, mas isto é secundário e mediado pelo fato de que, antes, seu sofrer e sua carência nos perturbaram" (SCHOPENHAUER, 2001c, p. 139). No entanto, poder-se-ia aqui ainda observar, esta assertiva parece também ser invalidada por aquele critério descrito acima: pois um mal-estar do sujeito, este perturbar-se ou afligir-se (betrügen) do agente em relação ao sofrimento alheio - que levaria à tentativa de suprimi-lo - não pode ser tomado como a motivação moral, como a finalidade da ação, sob o risco de recairmos nas malhas do interesse e, assim, do egoísmo. Vê-se que a conclusão esperada para toda esta problemática, a saber, que na verdade toda ação é interessada, foi recusada terminantemente em solo schopenhaueriano: deveríamos pois navegar as tempestuosas águas de Zaratustra? Resta-nos ainda tratarmos do ascetismo.

\footnotetext{
${ }^{26}$ Como propõe Robert Misrahi em seu artigo Critique de la théorie de la souffrance dans l'ontologie de Schopenhauer (In: DROIT, 1989, p. 95-6).
} 
- Pessimismo e niilismo: a negação da vontade

Habituados à imagem schopenhaueriana do "pessimista incurável" (RIBOT, 1974, p. 4), que "oferece um pessimismo sem porta de saída" (SIPRIOT, 1988, p. 27), que promove a "liquidação do falso consolo de uma vida feliz" (CACCIOLA, 1994, p. 79), somos tomados inevitavelmente pelo estranhamento diante de sua entusiasmada apresentação do amor ao próximo da atitude compassiva. Talvez fosse adequado esperar que a visão de mundo trágica de Schopenhauer conduzisse diretamente à defesa do suicídio - pois que a vida se reduz à dor e ao sofrimento ou ao niilismo da negação da vontade do ascetismo apresentado nas últimas linhas de $O$ mundo como vontade e representação. Possivelmente aqueles caminhos paradoxais, os quais tiveram que percorrer sua análise sobre as virtudes morais, expliquem-se somente pela falta de jeito de um pessimista declarado (para quem o otimismo é mesmo um insulto) que tem que lidar com esta controversa questão da compaixão. Por este motivo talvez fosse adequado encarar a sua explanação sobre a moral não como o ponto final de seu discurso (como se vê nas interpretações que o tomam como uma filosofia do consolo ${ }^{27}$ ), mas antes como uma lacuna, ou um estranho objeto que com dificuldade consegue se encaixar naquilo que realmente deveria ser considerado o clímax do pensamento de Schopenhauer: a negação da vontade. "Como é possível a negação da vontade?", interroga Nietzsche, "como é possível o santo? - esta parece ter sido mesmo a questão pela qual Schopenhauer se tornou filósofo, e com a qual começou" (NIETZSCHE, 1992a, p. 53).

O suicídio, como se sabe, é rejeitado pelo filósofo como uma solução para o significado trágico da existência. O suicida não nega a vida como parece, mas apenas os obstáculos que se apresentam à sua fruição: trata-se pois de uma forma

\footnotetext{
27 "Se o diagnóstico de Schopenhauer pode ser visto como pessimista, este sendo o ponto de partida de sua ética, por outro lado o seu objetivo é prático-otimista, isto é, uma filosofia do consolo" (BARBOZA, 2000, p. 201).
} 
cega e apaixonada de afirmação da vida, de fraqueza, de debilidade das forças do intelecto que poderiam enfrentar e conduzir o aspecto trágico da vida a uma solução em seu próprio seio ${ }^{28}$.

O caminho para o Nada da atitude ascética é aberto assim pela visão de mundo trágica: "Por que há de orgulhar-se o homem?", pergunta Schopenhauer, "sua concepção é uma culpa, o nascimento, um castigo; a vida, uma labuta; a morte, uma necessidade" (SCHOPENHAUER, 1980, p. 189). De fato, a vida pode ser encarada como um pêndulo que oscila sem cessar entre o sofrimento e o tédio; os dias da semana de segunda a sexta, de labuta, cansaço e preocupação representariam o sofrimento, e o final de semana o tédio. A vida é como o andar, diz Schopenhauer, pois do mesmo modo que este é uma queda adiada a cada passo, aquela é uma morte adiada constantemente, a cada aspiração, a cada alimentação. Como filho de comerciante e criado para o comércio, Schopenhauer sabe bem o significado de um negócio mal gerenciado, como é a vida, cujos gastos não cobrem as despesas - cedo ou tarde, sabermos, vem a bancarrota. Diz Schopenhauer nos Parerga e paralipomena:

Parecemos carneiros a brincar sobre a relva, enquanto o açougueiro já está a escolher um ou outro com os olhos, pois em nossos bons tempos não sabemos que infelicidade justamente o destino nos prepara - doença, perseguição, empobrecimento, mutilação, cegueira, loucura, morte etc. (SCHOPENHAUER, 1980, p. 217).

Portanto, temos que concluir que toda biografia (Lebensgeschichte) é na verdade uma patografia (Leidensgeschichte) (SCHOPENHAUER, s/d-b, p. 428). A Vontade enquanto essência metafísica de todos os seres, em sua fome infinita, impele o homem à busca desenfreada e ininterrupta pela satisfação (sempre

\footnotetext{
28 "Próximos de nós se localiza uma região em que nos livramos de toda nossa miséria; mas quem é dotado da força para ali se manter?" (SCHOPENHAUER, s/d-b, p. 27). "O suicídio é uma questão colocada à natureza, da qual se exige resposta. Mas é uma ação desastrosa pois suprime a consciência que precisamente deveria receber a resposta" (SANS, 1990, p. 84).
} 
impedida por incontáveis obstáculos), sendo assim a carência e o sofrimento a conseqüência inevitável:

Para cada desejo satisfeito, dez permanecem irrealizados. Além disto, o desejo é duradouro, as exigências se prolongam ao infinito; a satisfação é curta e de medida escassa. O contentamento finito, inclusive, é somente aparente: o desejo, imediatamente dá lugar a um outro; aquele já é uma ilusão conhecida, este ainda não. Satisfação duradoura e permanente objeto algum do querer pode fornecer; é como uma caridade oferecida a um mendigo, a lhe garantir a vida hoje e prolongar sua miséria ao amanhã. Por isto, enquanto nossa consciência é preenchida por nossa vontade, enquanto submetidos à pressão dos desejos, com suas esperanças e temores, enquanto somos sujeitos do querer, não possuiremos bem-estar nem repouso permanente. Caçar ou fugir, temer desgraças ou perseguir o prazer, é essencialmente a mesma coisa; a preocupação quanto à vontade sempre exigente, seja qual for a forma em que o faz, preenche e impulsiona constantemente a consciência; sem repouso porém não é possível qualquer bem-estar. Destarte, o sujeito da vontade está constantemente preso à roda de Ixion, colhe continuamente pelas peneiras das Danaides, constitui o eternamente supliciado Tântalo (SCHOPENHAUER, 1980, p. 26).

No mundo fenomênico vemos aumentar a presença da dor e do infortúnio à medida que ascendemos na escala do seres, do inorgânico ao indivíduo de gênio, pois quanto mais complexo o organismo maior a sua sensibilidade e propensão ao sofrimento.

É deste modo que chegamos ao ascetismo, "o remédio radical e único para a doença, enquanto que todos os outros bens são puros paliativos, simples calmantes" (SCHOPENHAUER, s/d-b, p. 481). Não se trata meramente de uma afirmação consciente da vontade: esta foi completamente negada, o véu de Maya inteiramente rasgado. O asceta não é mais movido por motivos, sejam eles quais forem:

percebe o conjunto das coisas, conhece-lhes a essência, e vê que ela consiste num escoamento perpétuo, num esforço estéril, numa contradição íntima e num sofrimento contínuo; e ele vê que é a isso que estão votados, a miséria humana e a miséria animal e, enfim, um universo que se dissipa sem cessar [...] Então a vontade desliga-se da vida: ela vê nos prazeres uma afirmação da vida, e tem horror deles. O homem chega ao estado de abnegação voluntária, de resignação, de calma verdadeira e de ausência absoluta do querer [Willenlosigkeit]. Eles amam os seus sofrimentos e a sua morte, visto que entraram na negação do querer-viver, muitas vezes recusam mesmo a salvação que se lhes oferece e morrem voluntariamente, com tranqüilidade e felicidade (SCHOPENHAUER, s/d-b, p.522). 
O filósofo estabelece ainda quatro etapas em que o processo do ascetismo se desenvolve: 1) A castidade; 2) Pobreza voluntária; 3) Aceitação do sofrimento, casual ou provocado por outra pessoa; e 4) Mortificação do corpo: que não pode ser ativa, violenta, como no suicídio vulgar, mas deve ser passiva, uma espécie de inanição (como a despreocupação com a alimentação, por exemplo) ${ }^{29}$.

Eis o "consolo" oferecido pelo niilismo schopenhaueriano. Como afirma Lukács - citado por René-Pierre Colin em seu artigo Schopenhauer et le pessimisme naturaliste - "o sistema de Schopenhauer, de uma arquitetura sutil e de formas gerais claras, parece bem com um hotel provido de todo o conforto moderno, mas suspenso às margens de um abismo, do Nada, do absurdo" (In: SIPRIOT, 1988, p. 197).

Assim, "arrancados do querer nos abandonamos ao conhecimento puro independente da vontade, penetramos em um outro mundo, em que tudo que movimenta nossa vontade, e por isto nos abala com tal intensidade, não mais existe" (SCHOPENHAUER, 1980, p. 27). Um significativo contraste é observado neste estado de não-querer: a vontade ainda se afirma na existência do corpo, mas ao mesmo tempo se nega na independência do conhecimento em relação a ela, antes legisladora absoluta. Podemos dizer que estamos diante de uma Existentia sem Essentia (SCHOPENHAUER, 1982, p. 117) e concluir, de acordo com o fisiologismo dos Suplementos a O Mundo como vontade e representação, que "o sistema cerebral deve estar separado e inteiramente isolado do sistema ganglionar, de modo a estar em perfeita oposição com ele e a conduzir sem hesitação sobre o organismo sua vida de parasita, solitária, enérgica e independente" (SCHOPENHAUER, s/d-a, 203-4). Nesta conversão (Wendung), nesta rebelião do intelecto, suas formas do

\footnotetext{
${ }^{29}$ Neste ponto, talvez seja conveniente a remissão à crítica de Nietzsche ao ascetismo como uma forma de suicídio usada como alavanca de poder pelo cristianismo (NIETZSCHE, 2001, p. 151).
} 
espaço, tempo e causalidade não atuam mais - e com elas o conhecimento abstrato da razão. Trata-se de uma intuição pura, que percebe as coisas como são em si e não como motivos, como objetos relacionados entre si e com uma vontade individual fenomênica (o caráter empírico) - que já não mais existe, fôra suprimida (aufgehoben) no sujeito puro do conhecimento. Resta à filosofia, enquanto conhecimento por conceitos, apenas apontar de fora para fenômeno da negação da vontade, pois que the é vedado qualquer acesso direto ao paraíso perdido do não ser ${ }^{30}$, a esta terra incognita (ROSSET, 1989, p.23): possível, no entanto, aos santos, monges e, de forma parcial, ao gênio na arte.

As tortuosas linhas de $O$ mundo parecem pois ter nos conduzido em direção ao Nada:

A morte não põe só, como nos outros, termo à manifestação da vontade: a própria essência é suprimida, visto que o último resto de existência que lhe restava ligava-se a essa manifestação e a morte quebra esta frágil [linha]. Para aquele que acaba assim, o universo acaba ao mesmo tempo (SCHOPENHAUER, s/d-b, p.508). Uma vez conduzidos, pelas nossas especulações, a ver a santidade perfeita na negação e no sacrifício de todo o querer, uma vez libertados, graças à convicção, de um mundo cuja [existência] total se reduz para nós à dor, a última palavra da sabedoria consiste, para nós, daqui em diante, apenas em nos afundarmos no nada [vazio] [in das leere Nichts] (SCHOPENHAUER, s/d-b, p. 542).

Contudo, não se trata ainda de um Nada absoluto, pois a Vontade mesma não é um absoluto, mas está relacionada ao mundo como fenômeno: "se a Vontade só é a coisa em si de modo relativo e não absoluto, isto é, apenas com referência ao mundo como representação, pode-se pensar numa negação também relativa dessa vontade" (CACCIOLA, 1994, p. 127). De acordo com a distinção kantiana entre nihil privativum (Nada relativo) e nihil negativum (Nada absoluto: contradição lógica que

\footnotetext{
${ }^{30}$ Verlorenes Paradies des Nichtseyns, diz o filósofo nos Suplementos (SCHOPENHAUER, s/d-a, p. 277).
} 
se destrói a si mesma), da Tábua dos nadas da Crítica da razão pura (KANT, 1999,

p. 171$)^{31}$, conclui então que

\begin{abstract}
Se observarmos de mais perto, não existe nenhum nada absoluto; o nihil negativum propriamente dito não existe, não é uma noção pensável. Todo o nada deste gênero desde que o consideremos sob um ponto de vista mais elevado, desde que se subsuma sob um conceito mais extenso, não pode deixar de se reduzir ao nihil privativum. Todo o nada é qualificado de nada apenas em relação a uma outra coisa [...] a própria contradição lógica é apenas um nada relativo. É uma coisa que a razão não pode pensar, mas não se segue por isso que seja um nada absoluto (SCHOPENHUAER, s/d-b, p. 542-3).
\end{abstract}

Trata-se então de uma mudança de perspectiva: no mundo como Vontade a representação (e com ela todas as formas do conhecimento) é o Nada. Por outro lado, no mundo como fenômeno, para o principium individuationis, é o mundo como Vontade é que é o Nada: "quanto mais se nos aproxima uma face do mundo, mais se nos distancia a outra", diz o filósofo em Sobre a vontade na natureza (SCHOPENHAUER, 1982, p. 148), e conclui, nos caracteres finais de sua obra magna:

Para aqueles a quem a Vontade anima, aquilo que resta, após a supressão total da Vontade, é efetivamente o nada. Mas, ao contrário, para aqueles que se converteram e aboliram a vontade, é o nosso mundo atual, este mundo tão real com todos os seus sóis e todas as suas vias lácteas, que é o nada (SCHOPENHAUER, s/d-b, p. 546).

A notícia da descoberta deste paraíso do nada parece ter chegado há muito tempo por estes lados de cá, conforme se lê num poema de Augusto dos Anjos intitulado O meu Nirvana:

No alheamento da obscura forma humana,

De que, pensando, me desencarcero,

Foi que eu, num grito de emoção, sincero

\footnotetext{
${ }^{31}$ Num texto pré-crítico de 1763, intitulado Para introduzir na filosofia o conceito de grandeza negativa (KANT, 1949), Kant já apresentara tal distinção entre os dois nadas - que se multiplicam em quatro, na Crítica da razão pura, para se adaptarem às tábuas das categorias.
} 
Encontrei, afinal, o meu Nirvana!

Nessa manumissão schopenhaueriana,

Onde a Vida do humano aspecto fero

Se desarraiga, eu, feito força, impero

Na imanência da Idéia Soberana! 


\section{SCHOPENHAUER MUSICANTE}

\section{A METAFÍ́SICA DO BELO E O ACESSO À COISA EM SI}

Se a verdade sobre o enigma do universo deve vir do próprio mundo e não de uma Cucolândia nas nuvens - como afirma Schopenhauer em sua crítica ao Idealismo pós-kantiano - e se estamos conscientes de que os únicos modos de conhecimento de um objeto por um sujeito são a intuição e a razão, com suas formas da representação, do fenômeno, devemos então verificar a estranha proposta do terceiro livro de $O$ mundo de um acesso à realidade numênica da Vontade. De fato, a descoberta do mundo como Vontade trazida à luz por sua obra capital exige certos deslocamentos epistemológicos no texto de 1813. Schopenhauer encontrará em Platão a via adequada para tal reforma em sua teoria do conhecimento. Este estranho sentimento que temos de nossa própria vontade não pode ser tomado como um conhecimento direto da coisa em si, dado que as formas do conhecimento (tempo, espaço e causalidade) só fazem sentido no mundo como fenômeno. O objeto deste conhecimento da vontade será pois uma representação de um tipo especial, a representação adequada da Vontade - um grau intermediário entre a Vontade numênica e a mera vontade empírica (fenomênica) - também chamada de Idéia platônica; por sua vez o conhecimento capaz de apreender as Idéias é uma intuição, porém também atípica, uma intuição pura, despida das formas da representação empírica: 
Na minha exposição do princípio de razão, considerei a vontade, ou antes, o sujeito do querer, como uma categoria particular das representações ou objetos; mas nessa altura, eu já via esse objeto como confundindo-se com o sujeito, isto é, deixando de ser objeto; para mim, havia aí, nesta identificação, uma espécie de milagre (kat 'exokhén) é um conhecimento dum gênero especial, cuja verdade, por este motivo, não pode colocar-se em nenhuma das rubricas nas quais dispus toda a verdade, na minha exposição do princípio de razão, isto é: verdade lógica, empírica, metafísica e metalógica (SCHOPENHAUER, s/db, p. 135-6) ${ }^{32}$.

A Idéia ou vontade individual no homem será o caráter inteligível, conceito fundamental no âmbito de sua ética. Nos animais esta Idéia é representada pela espécie e no inorgânico pelas forças. Por serem anterior à pluralidade das individualidades fenomênicas, as Idéias são a universalia ante rem - os conceitos, extraídos da empiria, são a universalia post rem (a realidade mesma será a universalia in re). Estas Idéias serão o objeto da arte, como apontaremos.

A arte para Schopenhauer é um conhecimento, o mais importante de todos, pois enquanto a ciência e a filosofia se limitam às escassas possibilidades do conceito, ela tem como tarefa a intuição dos arquétipos platônicos, as Idéias. O conhecimento empírico é relacional, ou seja, os objetos são apreendidos em sua individualidade e enquanto estão relacionados entre si e com a vontade empírica do sujeito. Por outro lado a intuição objetiva do sujeito puro do conhecimento (reines erkennendes Subjekt) na contemplação artística ou da natureza percebe os objetos como são em si mesmos: nesta contemplação desinteressada, sujeito e objeto se tornam um só, dado que possuem a mesma essência. Aqui o intelecto alforria-se de seu algoz, a Vontade, ainda que tenha sido criado para servi-la através da concepção dos fenômenos: meros motivos (Motive) para a sua satisfação. Trata-se pois de "uma forte excitação da atividade cerebral intuitiva, sem qualquer excitação das inclinações ou das paixões [Affekte]" (SCHOPENHAUER, s/d-a, p. 179), observa

\footnotetext{
${ }^{32}$ Apenas a forma geral da representação pertence às Idéias: o ser-objeto-para-um-sujeito (Objekt-für-einSubjekt-sein) (SCHOPENHAUER, 1980, p. 9).
} 
Schopenhauer nos Suplementos ao terceiro livro de O mundo (dentre os quatro, um para cada livro, publicados na segunda edição de 1844).

O gênio, na arte, representa o ponto máximo deste conhecimento objetivo, aquele que com maior facilidade consegue se manter nesta contemplação desinteressada, podendo assim comunicar seu conhecimento através da reprodução (Abbild) das Idéias na obra de arte. Enquanto o cientista é dotado apenas de talento (Talent), o dom pertence ao gênio, sendo inato e não comunicável. O primeiro, cuja figura mais representativa seria Aristóteles, conhece o "como" e o "porquê" das coisas; o segundo, no entanto - Platão sendo seu representante -, conheceria o "quê".

Constitui uma característica do gênio a vontade intensa, um caráter violento e apaixonado e, em compensação, uma energia cerebral mais forte ainda, ou seja, uma violência apaixonada da vontade aliada a uma exaltação da vida nervosa, um "excesso anormal de inteligência" (SCHOPENHAUER, s/d-a, p. 189), ou ainda, uma "enorme preponderância da vida cerebral" (SCHOPENHAUER, 1982, p. 100), diz o filósofo em termos ainda mais fisiologicistas em Sobre a vontade na natureza ${ }^{33}$. A atividade inspirativa do gênio é encarada por Schopenhauer como a "atividade de um ser sobre-humano [übermenschlichen]", em que "são dominados freqüentemente por afecções violentas e paixões irracionais" (SCHOPENHAUER, 1980, p. 20-1). Como exemplo deste caminho tortuoso do gênio e de seu particular infortúnio em relação ao infortúnio do homem comum - este "produto industrial da natureza" (SCHOPENHAUER, 1980, p. 18) - Schopenhauer cita o Torquato Tasso de Goethe, "que situa a nossos olhos não somente o sofrimento, o martírio essencial do gênio

\footnotetext{
${ }^{33}$ A respeito dos requisitos para a genialidade, apresentada nos Suplementos, diz ele: é necessário "o máximo de energia da atividade cerebral, a qual depende do frescor e da elasticidade das fibras e da força com a qual o sangue arterial flui para o cérebro" (SCHOPENHAUER, s/d-a, p. 214); e mais: "uma noite inteira de um sono tranqüilo, um banho frio, e tudo o que, acalmando a circulação e a força das paixões, dá à atividade cerebral uma predominância adquirida sem esforço" (SCHOPENHAUER, s/d-a, p. 180).
} 
como tal, mas também sua constante transição à loucura" (SCHOPENHAUER, 1980, p. 22). Esta proporcionalidade entre genialidade e sensibilidade para o sofrimento parece não ter passado despercebido também a Nietzsche no instante em que se refere à felicidade de Homero, sua fruição de uma alma forte, ousada, temerária: "quem tem na alma essa felicidade de Homero é também a criatura mais capaz de sofrimento que existe sob o sol!" (NIETZSCHE, 2001, p. 204-5) ${ }^{34}$. Resta pois ser verificado o status desta afecção violenta e deste martírio do gênio que o torna ao mesmo tempo um sujeito isento de vontade, afirma Schopenhauer, e livre de toda a miséria humana.

Esta negação da vontade da experiência artística, em que se observa o divórcio entre a vontade e o intelecto - ainda que imperfeito e temporário (em comparação com a negação total do querer do ascetismo) -, vista a partir da perspectiva do espectador, leva-nos a concluir, com Schopenhauer, que "o grau desta separação estabelece grandes diferenças intelectuais entre os homens; pois o conhecer é tanto mais objetivo e exato quanto mais se desligou da vontade; como é melhor o fruto que não tem o gosto do solo em que nasceu" (SCHOPENHAUER, 1982, p. 128). O gozo desinteressado do sentimento do belo advém de uma relação não hostil entre o objeto contemplado e a vontade do sujeito. No sentimento do sublime, no entanto, a vontade do indivíduo se vê numa relação hostil e desfavorável com o objeto (como na tragédia, por exemplo) - o sublime dinâmico (violência da natureza) e o sublime matemático (pequenez do indivíduo diante da incomensurabilidade do mundo exterior) serão conceitos inspirados na Crítica do juízo kantiana. O sublime se instaura neste contraste: a violência da natureza por um lado e do outro a consciência do indivíduo em ser o portador (Träger) de todo este espetáculo do mundo fenomênico (ainda que aterrorizante) o que confere ao sujeito

\footnotetext{
${ }^{34}$ Em Além do bem e do mal o filósofo aponta para a fragilidade e sensibilidade do "homem superior" (NIETZSCHE, 1992a, p. 65).
} 
puro do conhecimento o título de olho do mundo (Weltauge) (SCHOPENHAUER, s/d-a, p. 183).

Sendo assim, Schopenhauer disporá hierarquicamente as diferentes manifestações artísticas, da arquitetura à música de acordo com o grau de objetivação da Vontade, isto é, conforme a maior ou menor facilidade da arte em elevar o indivíduo a sujeito puro do conhecer - a arquitetura, por exemplo, tem como objetivo a reprodução dos graus mais inferiores da objetivação da Vontade (as qualidades ocultas) e seu antagonismo, sua luta interna (gravidade, coesão, rigidez, dureza, etc.), ao passo que a pintura e escultura históricas têm como objeto o homem, a outra ponta na escala da objetivação.

Em pouco mais de três parcas páginas, apresenta Schopenhauer o que considera o ápice da arte poética: a tragédia. A essência desta arte consiste na exposição de um infortúnio, do conflito interno da Vontade consigo mesma. São três as formas de apresentação deste conflito: 1) através da representação de uma perversidade extraordinária, um caráter maligno; 2 ) do acaso do destino cego (como em Édipo rei de Sófocles); 3) ou pela simples disposição dos indivíduos, em que o infortúnio surge de uma situação corriqueira - o tipo predileto de Schopenhauer, pois possibilita uma melhor identificação do espectador com a cena: "horrorizados, já nos sentimos em pleno inferno" (SCHOPENHAUER, 1980, p. 72). Seguindo as pegadas de Aristóteles (diferentemente de Nietzsche), Schopenhauer destaca o caráter catártico da tragédia, em que o espectador

purificado e elevado pelo próprio sofrimento, atinge o ponto em que o fenômeno, o véu de Maya, já não mais ilude, é percebida a forma do fenômeno, o principium individuationis, desaparece o egoísmo nele baseado, com o que os motivos, outrora poderosos perdem seu poder, e em seu lugar o conhecimento perfeito da essência do mundo, atuando como quietivo da Vontade, apresenta a resignação, a renúncia, não unicamente da vida, mas mesmo de todo querer-viver [Wille zum Leben] (SCHOPENHAUER, 1980, p. 70). 
Para Schopenhauer o sentido desta arte "constitui a visão mais profunda, de que o herói expiou não foram seus pecados particulares, mas sim o pecado original, isto é, a culpa da existência ela própria" (SCHOPENHAUER, 1980, p. 71). Veremos que a mesma perda da individualidade na análise da tragédia no jovem Nietzsche não pretende conduzir, no entanto, ao quietivo da vontade de Schopenhauer, mas antes a uma elevação ou atividade desta. No entanto, esta questão da contraposição entre atividade e passividade da Vontade não é tão simples quanto possa parecer, como verificamos acima no fenômeno da compaixão e como procuraremos indicar na análise da música.

Diferentemente de todas as artes, a música não se faz expressar por uma matéria qualquer, como a arquitetura ou a poesia (os conceitos), ela é propriamente objetivação adequada da Vontade, assim como a Idéia platônica, enquanto as outras expressões artísticas são cópias destas Idéias; elas se referem apenas à sombra (Schatten) ao passo que a música está ligada à essência. As linhas dedicadas pelo filósofo à música, no terceiro livro de $O$ mundo, são possivelmente também as que mais tiveram reconhecimento pela sua originalidade e beleza, em especial por parte de Richard Wagner e pelo Nietzsche de O nascimento da tragédia.

A explicação sobre a música esbarra em uma dificuldade intransponível, a saber, ela é uma manifestação direta de algo que de forma alguma pode ser uma representação: a Vontade. Deste modo, diz o filósofo, sua apresentação deve ser meramente analógica: como complemento indispensável à sua exposição teórica Schopenhauer aconselha a vivência com a própria arte em questão. Se podemos afirmar, com o filósofo, que o mundo pode ser tomado tanto como Vontade corporificada quanto música corporificada, a filosofia, enquanto expressão da essência do mundo por conceitos, caso alcance a finalidade de uma expressão correta da essência da música "imediatamente seria também uma reprodução e 
explicação suficiente do mundo mediante conceitos" (SCHOPENHAUER, 1980, p. 80). Nos Suplementos Schopenhauer traça um paralelo entre as manifestações da Vontade e as partes componentes da música: "as quatro vozes de toda harmonia, a saber, o baixo, o tenor, o alto e o soprano; ou, noutros termos: tom fundamental, terça, quinta e oitava, correspondem aos quatro graus da escala dos seres, ou seja, aos reinos mineral, vegetal, animal e ao homem" (SCHOPENHAUER, s/d-a, p. 258). Deste modo, assim como toda a variedade de vozes de uma harmonia (da mais grave a mais aguda) deriva do baixo, a variedade dos tons se origina daquele tom mais grave, o tom fundamental (Grundton), do mesmo modo as individualidades fenomênicas têm sua origem na informe massa do planeta: "há um limite para a gravidade dos tons, além do qual nenhum mais é audível; isto corresponde a que matéria alguma é perceptível sem forma e qualidade" (SCHOPENHAUER, 1980, p. 74). Mesmo a contradição interna da Vontade consigo mesma (notada no segundo livro de $O$ mundo) tem sua representação na música: as dissonâncias; os números das escalas musicais guardam irracionalidades insolúveis, deste modo, assim como um mundo perfeito não pode mesmo ser imaginado, diz ele, "uma música perfeitamente correta não pode sequer ser pensada, quanto mais executada" (SCHOPENHAUER, 1980, p. 81). Assim, as dissonâncias são ocultadas através do temperamento, da sua distribuição a todos os tons.

Nas vozes que compõem a harmonia, Schopenhauer reconhece na voz condutora que executa a melodia, a voz aguda, a expressão do reino humano (a forma mais elevada de objetivação da vontade), enquanto as demais vozes, intermediárias, em sua dissonância e falta de conexão representam os graus inferiores de objetivação da Vontade - o filósofo analisa detalhadamente os diversos movimentos e escalas musicais traçando um paralelo entre eles e as características dos reinos inorgânico, vegetal e animal. A melodia, com sua integridade em relação 
às demais vozes, relata, de algum modo, "a história da vontade iluminada pela reflexão [Besonnenheit], cuja impressão na realidade efetiva constitui a série de seus atos"; além disso, relata ela também "sua história mais secreta, descreve toda agitação, todo impulso, todo movimento da vontade, tudo o que a razão reúne sob o amplo e negativo conceito de sentimento [Gefühl" (SCHOPENHAUER, 1980, p. 75). Cabe aqui uma observação, pois o leitor de Schopenhauer habituado a essa terra de paradoxos que é a sua filosofia, pode ter percebido diante de si um intrigante problema, a saber, como pode a melodia na música representar tal história da vontade iluminada pela reflexão - pois "unicamente a melodia possui conexão significativa, intencional, do começo ao fim" (SCHOPENHAUER, 1980, p. 75) sendo que um pouco mais adiante é afirmado enfaticamente (como em muitos outros momentos de sua obra) que o conceito é infrutífero e estranho para a música e para a arte em geral: mais ainda, o trabalho do gênio se dá

\begin{abstract}
longe de toda reflexão e intencionalidade consciente, e poderia se denominar uma inspiração [...] O compositor revela a essência mais íntima do mundo e a mais profunda sabedoria, em uma linguagem incompreensível à sua razão; assim como um sonâmbulo magnético [denominação, na época, para alguém hipnotizado] fornece informações sobre coisas, de que em vigília não possui noção alguma (SCHOPENHAUER, 1980, p. 76).
\end{abstract}

Como é possível, poder-se-ia indagar, no mesmo impulso artístico (presente na melodia) termos a expressão de uma ordem e intencionalidade desta vida reflexiva do homem e ao mesmo tempo esta embriagante e irracional atividade inspirativa, da qual o gênio é o representante maior? Uma saída para este paradoxo não seria justamente a tese nietzschiana dos impulsos apolíneo e dionisíaco? Veremos, no capítulo que se segue, mais de perto esta questão.

Outro paradoxo sobre o qual se inscreve a teoria schopenhaueriana da música diz respeito ao paralelismo traçado entre ela e as Idéias platônicas. Schopenhauer afirma que a música é percebida única e exclusivamente no tempo. 
No início do terceiro livro de $O$ mundo, no entanto, as Idéias (enquanto objetivações imediatas da Vontade) são privadas das formas do entendimento (tempo, espaço e causalidade) com a exceção da "forma primeira e mais geral, a da representação em geral, do ser objeto para um sujeito" (SCHOPENHAUER, 1980, p. 10). De que modo poderia então uma objetivação adequada da Vontade, como o é a música, apresentar-se no tempo, uma das formas do princípio de individuação, é algo a ser questionado. Este paradoxo liga-se àquele do sujeito puro do conhecimento, uma espécie de individualidade em si, fora do tempo e do espaço. Talvez devêssemos pensar numa outra concepção da temporalidade, própria à da música, ainda não mesclada à espacialidade, o que nos remete à terceira classe de representações apontada pelo filósofo em sua Dissertação Sobre a quádrupla raiz.

A despeito destes paradoxos, não deixa de impressionar a analogia feita pelo filósofo entre os movimentos da melodia e os sentimentos humanos, o que remete à sua visão de mundo pessimista e, além disto, traz novamente à baila a discussão sobre a relação com Nietzsche. A essência do homem consiste, segundo Schopenhauer neste eterno movimento: do desejo à satisfação e da satisfação ao novo desejo. Um desejo obstado leva ao sofrimento; a permanência duradoura em um estado de satisfação leva ao tédio:

\begin{abstract}
Assim em conformidade, a essência da melodia é um vagar contínuo, um desvio do tom fundamental, por caminhos mil, não somente em direção aos graus harmônicos, terça e dominante, mas a todo tom, à sétima dissonante e graus ulteriores; mas sempre segue um retorno finito [endliches Zurückkehren] ao tom fundamental; em todos estes caminhos a melodia exprime o impulsionar múltiplo da vontade, porém sempre também mediante o reencontro finito [endliches Wiederfinden] de um grau harmônico, e mais ainda do tom fundamental, a satisfação (SCHOPENHAUER, 1980, p. 76). (grifos nossos)
\end{abstract}

A música não representa, no entanto, este ou aquele determinado fenômeno físico ou psíquico: em relação aos sentimentos, por exemplo, ela não se refere senão que de forma indireta a determinada alegria ou dor individual (ou 
aflição, júbilo, humor etc.), mas exprime antes a própria alegria e a própria dor, independente dos motivos que os ocasionam. Neste sentido, a ópera é uma arte que procura justamente figurar todo este mundo fantasmagórico, como designa Schopenhauer. Mas a música não pode ter aí um papel secundário, não pode ser um simples meio de expressão; deste modo, "quando a música procura se apegar demais às palavras, e se acomodar aos acontecimentos, ela se esforça em falar uma linguagem que não é a sua" (SCHOPENHAUER, 1980, p. 77). A propósito, a crítica à ópera como uma arte não-dionisíaca acompanha boa parte da obra de Nietzsche: já em O nascimento da tragédia, a diminuição da importância da música como é observada em Eurípides (por influência da figura apolínea de Sócrates) - é tomada como o ponto de partida do declínio da tragédia grega.

Em relação ao finito reencontro da análise schopenhaueriana (o finito na verdade se refere ao caráter temporário do estado de contentamento, pois logo se segue o novo impulso em direção ao sofrimento), como não pensar aqui no eterno retorno de Nietzsche? Um detalhe (e não é pequeno) separa, neste sentido, os dois filósofos: o ascetismo apresentado no quarto livro de $O$ mundo em que este eterno reencontro, a roda de Ixion $^{35}$, é detida definitivamente. Entretanto, o consolo oferecido pela arte (em Nietzsche também encontramos o termo consolo utilizado em relação à arte trágica), o entusiasmo [Enthusiasmus] do artista, se dá ainda no interior do próprio movimento da Vontade; se a roda de Ixion (o castigo divino) encontra aqui seu repouso temporário, se na contemplação desaparecem as mazelas decorrentes da voluptuosidade do sôfrego querer, entretanto um outro movimento é aqui intensificado. O artista, diferentemente do santo

\footnotetext{
${ }^{35}$ A respeito da "roda de Ixion": conferir a citação no capítulo Pessimismo e niilismo: a negação da vontade, p. 51.
} 
é cativado pela observação do espetáculo da objetivação da vontade; ali se detém, não se cansa em sua contemplação e reprodução, e entrementes sustenta os custos da apresentação deste espetáculo, isto é, ele mesmo é a vontade que se objetiva, e permanece em contínuo sofrimento [Leiden](SCHOPENHAUER, 1980, p. 82).

A música é vontade corporificada, por isto nos arrasta tão irresistivelmente para fora de nossa vivência cotidiana - ou pelo menos no-la apresenta em outra perspectiva - pois ela se situa numa realidade em que o histórico, o urgente, o cotidiano, com suas formas da temporalidade e espacialidade, são-nos indiferentes. Assim, a arte do gênio o torna livre deste infortúnio e sofrimento (Qual) do mundo fenomênico. No entanto, se tivermos em mente a forma como foi descrito o indivíduo de gênio, com sua extrema sensibilidade e o sofrimento exacerbado pela visão trágica que o autoconhecimento da Vontade oferece, perceberemos que o apaziguamento da vontade na experiência estética não significa de modo algum uma perda de atividade, uma passividade. A diferença apresentada no último parágrafo do terceiro livro de $O$ mundo entre a miséria ou sofrimento (Qual) do qual o artista está livre e o sofrimento (Leiden) do qual ele não encontra saída é significativa: aqui se apresenta o que entendo por trágico no pensamento de Schopenhauer, e este trágico se revela no bojo de sua teoria da música. Como foi dito, pode-se perceber um paralelo entre a relação do tom fundamental na melodia com os outros diversos tons e a relação desejo-satisfação-sofrimento-tédio. Assim como um prolongado tom fundamental é insuportável na música, do mesmo modo não se suporta um estado de satisfação excessivamente estendido, pois logo advém o peso esmagador do tédio (que não é um infortúnio menor que o sofrimento da dor, a busca - não lograda - pela satisfação): em suma, não só não existe escapatória, como se pode mesmo concluir que o sofrimento é desejado, buscado, pela própria Vontade, na sua fuga do tédio, do estado de repouso da satisfação. O contentamento, a satisfação em si, não pode ser o fim almejado; é no processo 
mesmo, nesta atividade interna da Vontade, no eterno círculo do sofrimento, que consiste o próprio fim da vida. A arte é aquele estado excepcional em que se escapa àquele círculo do conflito e sofrimento no nível fenomênico para uma vivência naquele outro círculo - a atividade da Vontade, na arte, não é pois diminuída ou enfraquecida.

Com estes apontamentos sobre o tragicismo na estética schopenhaueriana e o problema da atividade/passividade na discussão sobre o conceito de compaixão desenvolvido acima, temos os elementos suficientes para uma análise da crítica nietzschiana ao niilismo passivo de Schopenhauer.

\section{APOLO E DIONÍSIO}

Um pessimista, um negador de Deus e do mundo, que se detém diante da moral - que diz "sim" à moral e toca flauta, a moral do neminem laede [não faça mal a ninguém]: como? Este é verdadeiramente - um pessimista?

Nietzsche (Além de bem e mal § 186)

O estudioso de Schopenhauer que se aventura à leitura da obra do autor de Assim falou Zaratustra, sabendo que a filosofia schopenhaueriana ganha lugar de destaque no alvo da furiosa crítica do último Nietzsche, esbarra em algumas inquietantes indagações, que afloram já a partir de $O$ nascimento da tragédia, como 
as abaixo descritas e que serão investigadas no decorrer da análise da crítica de Zaratustra ao niilismo da Tradição:

1) Até que ponto a tese sobre as individualidades apolínea e dionisíaca permite uma aproximação da distinção schopenhaueriana entre sujeito puro do conhecimento e sujeito empírico (ou ainda: caráter inteligível e empírico)?

2) O erro fundamental de Schopenhauer, diz Nietzsche, seria o de colocar lado a lado o fenômeno estético e o ético. Se Nietzsche os distingue, rebaixando a Moral ao âmbito da aparência (como é afirmado em sua Tentativa de autocrítica, o prefácio tardio de $O$ nascimento da tragédia), onde estaria o ponto desta cisão? Como justificá-la, tendo em vista que, em Schopenhauer, ambos os fenômenos são considerados a partir da perspectiva da perda da individuação, característica fundamental da experiência estética também em Nietzsche?

3) Se tomamos a distinção apolíneo-dionisíaca nietzschiana como relacionada à distinção Vontade-Representação de Schopenhauer, como pode ser traçada (e em que momento da obra de Nietzsche) uma diferença entre os dois autores? Em que momento a Vontade nietzschiana deixa de ser metafísica?

O plano nietzschiano traçado neste pequeno escrito de Basel $^{36}$, que se tornaria sua primeira publicação, não deixa dúvidas: inspirado em Schopenhauer e Wagner, pretende analisar a odisséia do nascimento e morte da tragédia no espírito grego, bem como a possibilidade do renascimento da mesma em solo alemão. Que não seja esperada, no entanto, uma mera história da arte: Nietzsche tomará, a partir deste ensaio, seu lugar definitivo entre os grandes nomes do Panthéon filosófico. Como o mais implacável crítico da Moral, trata-se, já aqui, de analisá-la sob a ótica da vida, sentencia ele na Tentativa de autocrítica, ou ainda, de "ver a ciência com a óptica do artista, mas a arte com a da vida" (NIETZSCHE, 1992b, p. 15). Se a

\footnotetext{
${ }^{36}$ Ou Basiléia, importante cidade no extremo norte da Suíça, divisa com a Alemanha, onde Nietzsche exercia a cátedra de filologia clássica.
} 
metafísica schopenhaueriana constitui o pano de fundo do estudo dos dois impulsos artísticos (apolíneo e dionisíaco), é a arte, contudo, que será apresentada como a atividade metafísica por excelência do homem: em Nietzsche a metafísica do artista (já presente no terceiro livro de $O$ mundo como vontade e representação), no entanto, não dá ensejo ao passo seguinte dado pelo quarto livro da obra capital de Schopenhauer (em direção à metafísica do santo). É barrada toda possibilidade de fundamentação metafísica da moral, que Schopenhauer estabelecera seguindo os passos da Crítica kantiana.

Mais adiante, é a própria metafísica a ser condenada pela irascibilidade das palavras de Nietzsche: "como ridentes mandeis um dia ao diabo toda a 'consoladoria' metafísica - e a metafísica, em primeiro lugar!"(NIETZSCHE, 1992b, p. 23), escreve o filósofo em 1888. As invectivas ao otimismo do racionalismo cientificista, ou socratismo, deverão acompanhar ainda por muito tempo os movimentos da pena de Zaratustra. Em que medida o próprio Schopenhauer pode ser incluído neste otimismo criticado por Nietzsche, o Schopenhauer que toca flauta diariamente e é adepto do niilismo moral do neminem laede, é algo a ser verificado. Não estaria Schopenhauer, em suas sessões de flauta à mesa de jantar após as refeições, atendendo à prescrição da divindade helênica que sentenciara ao Sócrates convalescente (nos últimos dias que antecederam sua morte): "Sócrates, faz música!"? Este mesmo racionalismo cientificista já fora devidamente criticado em O mundo como vontade e representação. Esta imagem do Schopenhauer musicante, pergunta-se, não poderia então representar, na prática, aquilo que em seus escritos o filósofo já havia estabelecido como os limites não ultrapassáveis do conhecimento teórico (filosofia e ciência), colocando nas mãos da arte as chaves do enigma da vida, portanto antecipando a idéia do Sócrates musicante de 0 nascimento da tragédia? De fato, a tão acentuada positividade essencial da dor na 
vida humana (o prazer é negativo) afasta qualquer possibilidade de uma perspectiva otimista em Schopenhauer. O reconhecimento disto vem do próprio Nietzsche: "o escrito sobre Schopenhauer, cuja leitura recomendo especialmente, mostra como um espírito enérgico e instintivamente afirmativo sabe extrair os impulsos mais benéficos também de um pessimista" (NIETZSCHE, 1995, p. 132).

Vejamos mais de perto os impulsos artísticos descritos nessa obra e a relação desta tese com a filosofia schopenhaueriana.

"Teremos ganho muito a favor da ciência estética se chegarmos não à intelecção lógica mas à certeza imediata da introvisão de que o contínuo desenvolvimento da arte está ligado à duplicidade do apolíneo e do dionisíaco", diz Nietzsche na abertura de O nascimento da tragédia (NIETZSCHE, 1992b, p.27). O plano da estética schopenhaueriana revela-se já aqui, não apenas na preocupação em escapar ao rarefeito abstracionismo, criticado duramente por este em Kant e nos seus sucessores ${ }^{37}$, mas também na denúncia dos limites do conhecimento teórico. O termo Anschauung (intuição ou, conforme tradução de J. Guinsburg, introvisão) é o mesmo usado por Schopenhauer para se referir à arte como o conhecimento imediato das Idéias platônicas - que se difere da mera intuição sensível do mundo fenomênico e do conhecimento racional das representações abstratas (conceitos).

Com o apolíneo e o dionisíaco Nietzsche nos apresenta exemplos palpáveis destes impulsos que constituem a essência de toda obra de arte. Apolo e Dionísio simbolizam respectivamente a "arte do figurador plástico [Bildner]" e a "arte nãofigurada [unbildlichen] da música" (NIETZSCHE, 1992b, p. 27). Trata-se então de analisar como, "através de um miraculoso ato metafísico da 'vontade' helênica" (NIETZSCHE, 1992b, p. 27), se relacionaram estas duas forças artísticas da

\footnotetext{
${ }^{37}$ A teia de aranha de conceitos, ou ainda: a cucolândia nas nuvens (Wolkenkuckucksheim) aristofanesca, escreve Schopenhauer em Sobre o fundamento da moral, (2001c, p. 52 e 57) criticando a falta de efetividade nas Éticas kantiana e pós-kantiana.
} 
natureza na tragédia grega. O artista, o trágico em especial, é tomado então como um imitador destas forças originárias. O mundo metafísico da Vontade schopenhaueriano aparece aqui travestido com a roupagem dionisíaca, do mesmo modo que o mundo da Representação, o fenômeno, é simbolizado pelo apolíneo. Cabe observar no entanto que se a unidade pode ser uma característica tanto da Vontade schopenhaueriana (pois, fora do tempo e do espaço, meras formas da representação empírica, não Ihe convém a pluralidade, relegada ao mundo como Representação) quanto da Vontade nietzschiana - o Uno-primordial (Ur-Ein) ou Mãe primordial (NIETZSCHE, 1992b, p. 102) - duas referências a esta Vontade em O nascimento da tragédia parecem destoar da tese sobre a unidade quando o filósofo se refere ao cerne mais íntimo das coisas como "as mães do ser" (Die Mütter des Seins) (NIETZSCHE, 1992b, p. 97 e 123). E Nietzsche as chama pelo nome: Ilusão, Vontade, Dor (Wahn, Wille, Wehe). Entretanto, a contravenção à unidade da Vontade é menos séria do que parece: de certo modo revela-se aqui tão somente o tragicismo na inseparabilidade entre a vida (que é Vontade, Wille) e a dor (Wehe); mas, poder-se-ia indagar, como entender o primeiro termo? Que ilusão é esta que aparece aqui aliada à Vontade? Antes de chegarmos a ela, precisamos compreender o significado dos impulsos artísticos citados bem como o outro impulso responsável pela morte da tragédia.

A despeito desta aparente caracterização plural da Vontade, toda outra referência a estes impulsos é efetuada, nesta obra, sob caracteres schopenhauerianos. Particularmente ilustrativos são os exemplos do sonho e da embriaguez utilizados por Nietzsche para figurar a relação apolíneo-dionisíaca: abundam aqui as fórmulas schopenhauerianas como, por exemplo, as do principium individuationis, Véu de Maya e formas do espaço, tempo e causalidade para caracterizar o apolíneo. No sonho, afirma Nietzsche, encontra-se a inspiração dos 
poetas gregos. O sonho é precondição de toda arte plástica e de toda poesia. É deste modo que Homero é anunciado como o triunfo da ilusão apolínea: "em sonho foi que o grande plasmador [Bildner] viu a fascinante estrutura corporal de seres super-humanos" (NIETZSCHE, 1992b, p. 28). Assim como a ilusão do sonho esconde uma determinada realidade, esta mesma realidade não é também nada mais que uma ilusão (como ensina Schopenhauer, citado nesta passagem) que esconde o mundo numênico da Vontade. Por isso o sonho é apenas aparência da aparência, diz Nietzsche, mostrando que Apolo reina tanto no mundo onírico quanto na fulgurante realidade empírica, ambos erigidos sob a lei do principio de individuação.

Pertence a Apolo, o artista onírico, "aquela limitação mensurada, aquela liberdade em face das emoções mais selvagens, aquela sapiente tranqüilidade do deus plasmador" (NIETZSCHE, 1992b, p. 29). Em meio ao mundo de tormentos (Schopenhauer) ou mundo de Sileno ${ }^{38}$ (Nietzsche), o consolador mundo apolíneo da individualidade permanece em sua onírica tranqüilidade. No entanto, que não nos deixemos de imediato ser seduzidos pela "esplêndida imagem divina do principium individuationis" (tal como o filósofo descreve o apolíneo), pela beleza, prazer e sabedoria da aparência (NIETZSCHE, 1992b, p. 30), pois, como também em Schopenhauer, pode-se considerar o "estado de individuação enquanto fonte e causa primordial de todo sofrer, com algo em si rejeitável" (NIETZSCHE, 1992b, p. 70) e é esta mesma visão de mundo pessimista, que o jovem Nietzsche percebe no mito grego de Dionísio Zagreu e que lera já no segundo e terceiro livros de O mundo como vontade e representação. Destarte, é Schopenhauer que surge novamente

\footnotetext{
${ }^{38}$ Na mitologia grega, Sileno era o velho companheiro de Dionísio, misto de embriaguez e sabedoria, do qual se ouviu a terrível profecia: o melhor bem para o homem é não ter nascido; o segundo: morrer o mais rápido possível. Pode ser lembrada aqui a sentença de Calderón de la Barca (1600-1681) em La vida es sueño: "Pues el mayor delito del hombre es haber nacido", citada algumas vezes por Schopenhauer.
} 
quando Nietzsche inicia sua análise do outro prazer estético, o do artista extático dionisíaco, na analogia com o estado de embriaguez:

\begin{abstract}
Schopenhauer nos descreveu o imenso terror que se apodera do ser humano quando, de repente, é transviado pelas formas cognitivas da aparência fenomenal, na medida em que o princípio da razão, em algumas de suas configurações, parece sofrer uma exceção. Se a esse terror acrescentamos o delicioso êxtase que, à ruptura do principium individuationis, ascende do fundo mais íntimo do homem, sim, da natureza, ser-nos-á dado lançar um olhar à essência do dionisíaco (NIETZSCHE, 1992b, p. 30).
\end{abstract}

Ao contrário do comedimento e autoconhecimento prescritos pelo templo apolíneo em Delfos, temos, na beberagem dionisíaca o efeito narcótico do completo auto-esquecimento.

Nesta deliciosa satisfação do Uno-primordial, o Véu de Maya despedaça-se, diz Nietzsche: as formas do princípio de individuação não impedem mais ao homem este sobrenatural sentimento de divindade, de união com o todo. Seguindo a idéia da autocontemplação da Vontade (já anunciada no subtítulo do quarto livro de 0 mundo) podemos dizer com Nietzsche que "nos gregos a 'Vontade' queria, na transfiguração do gênio e do mundo artístico, contemplar-se a si mesma" (NIETZSCHE, 1992b, p. 38). A propósito, em vista da estética da Vontade nietzschiana, podemos declarar com o filósofo que

como sabedores [Wissende], não formamos uma só e idêntica coisa com aquele ser que, na qualidade de único criador e espectador dessa comédia da arte, prepara para si mesmo um eterno desfrute. Somente na medida em que o gênio, no ato da procriação artística, se funde com o artista primordial do mundo, é que ele sabe algo a respeito da perene essência da arte; pois naquele estado assemelha-se, miraculosamente, à estranha imagem do conto de fadas, que é capaz de revirar os olhos e contemplar-se a si mesma; agora ele é ao mesmo tempo sujeito e objeto, ao mesmo tempo poeta, ator e espectador. (NIETZSCHE, 1992b, p. 47-8)

Nas artes plásticas o Uno-primordial necessita ainda da aparência prazerosa (apolíneo) para sua constante redenção (Erlösung). A música é a arte dionisíaca por excelência, é a expressão do Uno-primordial sem a figuração de 
Apolo - a música é metafísica pura, para falar com Schopenhauer, sem o intermédio da representação: tanto faz, portanto, dizer mundo como Vontade ou mundo como música, conclui ele em $O$ mundo. Destarte, reconhece Nietzsche em relação à Estética schopenhaueriana: "ele, mesmo sem esse guia do simbolismo dos deuses helênicos, reconheceu à música um caráter e uma origem diversos dos de todas as outras artes" (NIETZSCHE, 1992b, p. 97).

As outras expressões artísticas ainda necessitam das formas do espaço, tempo e causalidade para a sua atuação, para a manifestação da Idéia (Nietzsche utiliza também a terminologia platônica) ao passo que a música é, ela mesma, manifestação direta do dionisíaco, da Vontade. "A música é a autêntica idéia [grifo nosso] do mundo, o drama é somente um reflexo, uma silhueta isolada desta idéia" (NIETZSCHE, 1992b, p. 128), diz o filósofo, ou ainda: "a música é a idéia imediata dessa vida" (NIETZSCHE, 1992b, p. 102). Neste sentido, podemos afirmar com Nietzsche que a música (assim como os demais elementos da tragédia) é a universalia ante rem (NIETZSCHE, 1992b, p. 126) - expressão da Escolástica empregada por Schopenhauer para se referir à universalidade da Idéia que se contrapõe à do conceito, a universalia post rem.

A tragédia grega nasce deste encontro (miraculoso, diz Nietzsche) entre a serenojovialidade da arte apolínea e a embriaguez musical de Dionísio. Cabe agora indagar: por que tiveram os gregos, na época mais robusta e saudável de seu desenvolvimento espiritual, necessidade do sentimento trágico? Aqui verificamos um momento importante da argumentação nietzschiana. 


\section{A TRAGÉDIA}

Para entendermos o significado desta catártica manifestação artística (diria Aristóteles) entre os gregos, precisamos ir às raízes de um outro consolo metafísico presente entre os helenos: a criação do Olimpo. É por sentirem que a vida é em si mesma trágica que tiveram eles a necessidade de levar os deuses ao mundo olímpico assim como a tragédia ao palco do teatro. "O grego conheceu e sentiu os temores e os horrores do existir: para que lhe fosse possível de algum modo viver, teve de colocar ali, entre ele e a vida, a resplendente criação onírica dos deuses olímpicos" (NIETZSCHE, 1992b, p. 36), explica Nietzsche. A vida se torna, assim, legitimada e suportável pelo fato de os próprios deuses participarem deste infortúnio inescapável, como reza a sabedoria popular grega simbolizada pelo mito de Sileno, citado por Nietzsche: ao ser capturado pelo rei Midas e indagado sobre qual o bem mais desejável ao homem, diz o sábio companheiro de Dionísio:

Estirpe miserável e efêmera, filhos do acaso e do tormento! Por que me obrigas a dizer-te o que seria para ti mais salutar não ouvir? O melhor de tudo é para ti inteiramente inatingível: não ter nascido, não ser, nada ser. Depois disso, porém, o melhor para ti é logo morrer (NIETZSCHE, 1992b, p. 36).

Com a criação do mundo homérico revela-se então

o quão necessário é o inteiro mundo do tormento, a fim de que, por seu intermédio, seja o individual forçado a engendrar a visão redentora e então, submerso em sua contemplação, remanesça tranqüilamente sentado em sua canoa balouçante, em meio ao mar (NIETZSCHE, 1992b, p. 40). 
Nesta notável intuição nietzschiana o leitor de Schopenhauer perceberá ainda, em outras cores, a estrutura ontológica subjacente ao terceiro livro de $O$ mundo como vontade e representação, pois o artístico mundo homérico-apolíneo é tomado como um mundo visionário de aparências surgido de uma segunda aparência: se a arte é uma outra aparência (em contraposição à aparência do mundo empírico), diria agora Schopenhauer, o é de tal modo especial que permite a intuição do mundo das Idéias - ou visão redentora do Uno-primordial, concordaria Nietzsche, através do prazeroso medium apolíneo da arte plástica.

Ao lado da serenojovialidade homérica Nietzsche apresenta o segundo paradigma poético grego representado por Arquíloco, o poeta subjetivo, diziam os juízos estéticos que circulavam na época pós-kantiana. Seus versos plenos de paixão e ódio seriam a contraparte da objetividade do artista homérico. Convém então verificar a crítica de Nietzsche a esta distinção entre objetivo e subjetivo na arte e à idéia da contemplação desinteressada. Ver-se-á que a aparente contraposição a Schopenhauer nesta questão não existe de fato. Arquíloco, o representante maior da poesia lírica, é a demonstração para Nietzsche de que é possível ainda pensar a subjetividade no âmbito da arte. Entretanto, trata-se de uma subjetividade que não é a meramente empírica, pois esta, diz o filósofo, já foi renunciada no processo dionisíaco:

O "eu" do lírico soa portanto a partir do abismo do ser: sua "subjetividade", no sentido dos estetas modernos, é uma ilusão [...] Por essa razão, ele, como centro motor daquele mundo precisa dizer "eu": só que essa "eudade" [Ichheit] não é a mesma que a do homem empírico-real, desperto, mas sim a única "eudade" verdadeiramente existente [seiende] e eterna, em repouso no fundo das coisas, mediante cujas imagens refletidas o gênio lírico penetra como o olhar até o cerne do ser. Pensemos agora como ele, entre essas reproduções, avista também a si mesmo como não-gênio, isto é, seu "sujeito" [Subjekt], todo o tumulto de suas paixões e aspirações subjetivas dirigidas para uma determinada coisa que the parece real; se agora se nos afigurasse como se o gênio lírico e o não-gênio a ele vinculados fossem um só e como se o primeiro proferisse por si só aquela palavrinha "eu", então esta aparência não poderia mais nos transviar, como sem dúvida transviou àqueles que tacharam de lírico o poeta subjetivo (NIETZSCHE, 1992b, p. 44-5). 
É curioso observar que a longa citação da consideração schopenhaueriana sobre a lírica, que se segue a esta passagem, serve a Nietzsche justamente para colocar Schopenhauer como um destes estetas representantes da malograda contraposição entre o objetivo e o subjetivo. Schopenhauer descreve a experiência da arte lírica como um "estado de alma mesclado e dividido", em que se vive o sentimento do contraste entre o querer que preenche a consciência do cantante e a tranqüilidade do sujeito puro do conhecer. O passo em falso da interpretação nietzschiana está na interpretação deste sujeito puro do conhecimento de Schopenhauer como o antípoda do indivíduo dionisíaco buscado em seu ensaio, como o representante daquela serenojovialidade socrática (daquele racionalismo) em breve combatida como a motivação fundamental do declínio do espírito trágico grego e da cultura Ocidental em geral. Afirmamos, em contrapartida, que Schopenhauer já esteve às voltas com esta individualidade que deita raízes no ser, como diz Nietzsche, e é precisamente no conceito de sujeito puro do conhecimento que se verifica tal assertiva. Este, não é mais o mero indivíduo do mundo como representação, mas, como individualidade em si, como caráter inteligível, não pertence mais ao mundo fenomênico. Como pode ser pensada uma individualidade fora das formas do espaço, tempo e causalidade, ou seja, independente da pluralidade da realidade fenomênica, é uma questão espinhosa percebida por Schopenhauer e que não deixou de espantá-lo (o que não ocorreu a Nietzsche), sem que conseguisse dar uma resposta satisfatória a este platonismo imiscuído em sua Estética. Nos Parerga e Paralipomena exclama o filósofo:

A individualidade não repousa unicamente no principium individuationis e destarte não é inteiramente simples fenômeno, mas ela se enraíza na coisa em si, na vontade do indivíduo, pois seu próprio caráter é individual. Qual a profundidade aqui atingida pelas suas raízes, constitui uma das questões cuja resposta não empreendo (SCHOPENHAUER, 1980, 207). 
Somos então levados a concluir que a distinção entre gênio lírico e nãogênio nietzschiana pode ser aproximada à distinção entre os caráteres inteligível e empírico de Schopenhauer. De fato, pode-se ler em Nietzsche a definição do caráter como "pessoa insistentemente viva" (NIETZSCHE, 1992b, p. 59), enquanto o sátiro serve a Dionísio "fora do tempo e fora de todas as esferas sociais" (NIETZSCHE, 1992b, p. 60). Não é, pois no contraste (para usar a terminologia schopenhaueriana) entre o apolíneo e o dionisíaco que são arquitetadas as artes em geral e a tragédia especialmente? No drama de Ésquilo o titã Prometeu é descrito como este misto de apolíneo e dionisíaco - pois é caracterizado pela dupla tendência de, por um lado, tentar ser o "Atlas" dos indivíduos, em seu sacrilégio aos olímpicos e, por outro lado, pelo seu apolíneo pendor para a justiça. Destarte, pode Nietzsche afirmar que

na medida em que o sujeito é um artista, ele já está liberto de sua vontade individual e tornou-se, por assim dizer, um medium através do qual o único Sujeito verdadeiramente existente celebra a sua redenção na aparência [nossos grifos - que atentemos para a maiúscula no segundo sujeito, colocado por Guinsburg em sua tradução: diferenciação inexistente no original] (NIETZSCHE, 1992b, p. 47)

Poder-se-ia pois indagar: como atitudes tão distintas (a afirmadora dionisíaca e a negadora do sujeito puro do conhecimento) - atentando para a crítica dos escritos posteriores de Nietzsche - podem ser fundamentalmente descritas de forma idêntica? A questão da individualidade e do pessimismo grego aparece, portanto, como pano de fundo desta história da geração e concepção do gênero trágico na arte. O indivíduo dionisíaco não é destroçado pela terrível visão de Sileno graças à intervenção da magia terapêutica de Apolo. O exemplo da poesia lírica de Arquíloco nos serve (a partir do que foi dito do espírito musicante próprio ao impulso dionisíaco) para entendermos a essência da tragédia. A relação entre linguagem e música, entre a palavra e o som, configura-se esteticamente na distinção apolíneodionisíaca tanto na lírica quanto no trágico. A palavra, o conceito, na tentativa de 
imitação da música sofre decisiva influência dela; a música, como pertencente a um estrato estético inalcançável pela primeira, apenas a tolera:

\begin{abstract}
Justamente por isso é impossível, com a linguagem, alcançar por completo o simbolismo universal da música, porque ela se refere simbolicamente à contradição e à dor primordiais no coração do Uno-primigênio, simbolizando em conseqüência uma esfera que está acima e antes de toda aparência (NIETZSCHE, 1992b, p. 51).
\end{abstract}

Também na altitude dionisíaca habitada pela música, encontra Nietzsche o coro: contra a interpretação do significado político desta figura da tragédia e contra a tese de Schlegel do "espectador ideal", seguindo a indicação de Schiller o filósofo chama a atenção para a idealidade do coro e seu elemento de crítica de todo realismo na arte. O coro é uma muralha, um isolamento do mundo real. Deste modo, o sátiro é visto como o antípoda do homem civilizado. A fraqueza deste diante da profecia de Sileno o conduziria ao refúgio nos confortantes braços do Estado (outra virtuose apolínea) ou à niilista negação budista da vontade. Ao invés da solução ética, Nietzsche propõe, através do trágico, o consolo metafísico da arte. O coro é o "auto-espelhamento do próprio homem dionisíaco" (NIETZSCHE, 1992b, p. 58), "com cujos sofrimentos [o espectador] já havia se identificado" (NIETZSCHE, 1992b, p. 62). Cabe lembrar que é esta mesma identificação (juntamente com a idéia da perda da individuação) que está no cerne da explicação schopenhaueriana do fenômeno ético da compaixão. A semelhança salta ainda mais à vista quando estamos diante da descrição nietzschiana do aniquilamento do herói trágico, o que nos remete imediatamente às linhas de $O$ mundo como vontade e representação nas quais a tragédia é analisada em pormenor: o herói na tragédia, diz Nietzsche, "a mais elevada aparição da vontade, é, para o nosso prazer, negado, porque é apenas aparência, e a vida eterna da vontade não é tocada de modo nenhum por seu aniquilamento" (NIETZSCHE, 1992b, p. 102). 
Mais ainda (estranha sentença diante da característica principal da crítica posterior de Nietzsche ao nilismo schopenhaueriano, da atitude "afirmadora da vida"), o herói trágico nos liberta "da ávida impulsão para esta existência" (NIETZSCHE, 1992b, p. 125). Só podemos entender acertadamente esta problemática se tivermos em mente que em $O$ nascimento da tragédia o jovem professor de Basel ainda não é o "fenomenista puro" (BRUM, 1998, p. 66) e que o conceito de existência, aqui, gravita em torno da distinção schopenhaueriana entre Representação e Vontade. Somente assim poderemos entender a afirmação de Nietzsche de que "a arte dionisíaca quer nos convencer do eterno prazer da existência: só que não devemos procurar esse prazer nas aparências, mas por trás delas" (NIETZSCHE, 1992b, p.102).

Entrementes, Nietzsche negará ao fenômeno da compaixão qualquer aproximação com este consolo metafísico oferecido pela arte dionisíaca, na qual "a luta, o tormento, a aniquilação das aparências se nos afiguram agora necessários" (NIETZSCHE, 1992b, p. 102) dada a abundância de seres que, acotovelando-se, são despejados na existência pela prodigalidade da Vontade, a mãe primordial: "apesar do medo e da compaixão, somos os ditosos viventes, não como indivíduos, porém como o uno vivente, com cujo gozo procriador estamos fundidos" (NIETZSCHE, 1992b, 103). Trata-se de afirmar esta dor inerente à vida e tirar desta afirmação todo o prazer que a arte pode proporcionar: eis a redenção operada pela tragédia.

Numa espécie de inversão de perspectiva quanto ao significado da luz no mito da caverna platônico, escreve Nietzsche, a respeito deste perigoso (porém prazeroso) auscultar no cerne mais íntimo da trágica existência: 
conhecido fenômeno óptico. Quando, numa tentativa enérgica de fitar de frente o Sol, nos desviamos ofuscados, surgem diante dos olhos, como uma espécie de remédio, manchas escuras: inversamente, as luminosas aparições dos heróis de Sófocles, em suma, o apolíneo da máscara, são produtos necessários de um olhar no que há de mais íntimo e horroroso na natureza, como que manchas luminosas para curar a vista ferida pela noite medonha. (NIETZSCHE, 1992b, p. 63) ${ }^{39}$

É precisamente com este olhar que Nietzsche analisa o Prometeu acorrentado de Ésquilo e o Édipo rei de Sófocles no nascimento da tragédia ática. O primeiro representa a glória da atividade e subversão aos deuses olímpicos, através da revolta de Prometeu e a crença numa justiça eterna a prevalecer em favor dos homens. Édipo representaria, por sua vez, a glória da passividade, o aceitamento passivo diante do castigo imposto pela divindade. Temos aí, diz o filósofo, a contraposição entre o santo (Édipo) e o artista (Prometeu) - poder-se-ia talvez perguntar se estaríamos autorizados aqui a pensar nas duas fases do espírito (camelo e leão) das Três transmutações de Assim falou Zaratustra (talvez a obra mais conhecida de Nietzsche). Tanto no áspero orgulho do hino à impiedade prometéico quanto no consolo metafísico edipiano, percebe-se a mesma penalidade, a condenação ao sofrimento como castigo divino pela mais pesada das contravenções: a descoberta dos segredos inescrutáveis guardados pelos seres olímpicos, o rompimento com "as mais sagradas ordens da natureza", pois "foi quebrado o sortilégio do presente e do futuro, a rígida lei da individuação e mesmo o encanto próprio da natureza" (NIETZSCHE, 1992b, p. 64-5). Conquanto nos vejamos confrontados com as mais aterrorizantes visões, "a mais profunda alegria humana nos domina diante dessa divina contraparte da dialética" (NIETZSCHE, 1992b, p. 64). Com Sófocles e Ésquilo o impulso apolíneo se vê forçado ao serviço

\footnotetext{
${ }^{39}$ Semelhante simbologia poderia também ser aplicada na inversão operada por Schopenhauer a respeito da relação entre o conhecimento intuitivo e o racional (a "luz" da razão). Despido de suas formas (espaço, tempo e causalidade), o entendimento no sujeito puro do conhecimento (na contemplação estética, por exemplo) mergulha na penumbra insondável do mundo como Vontade. Doravante, a verdade não habita o luminoso mundo exterior à obscuridade impenetrável da caverna, não é mais o não-escondido, o não-esquecido ( $a$ létheia), mas o que se esgueira no limbo mais tenebroso do Hades da Vontade cega. Ainda que a cicuta socrática tente conduzir a filosofia a seu encontro, em seu sono de Psiqué ela não poderá de lá retornar com a boa nova.
} 
de Dionísio. Segundo Nietzsche, seria a música na tragédia a responsável pela libertação de Dionísio das correntes prometéicas, do jugo dos deuses olímpicos aos Titãs. Destarte, temos aí

\begin{abstract}
uma profunda e pessimista consideração do mundo e ao mesmo tempo a doutrina misteriosófica da tragédia: o conhecimento básico da unidade de tudo o que existe, a consideração da individuação como causa primeira do mal, a arte como a esperança jubilosa de que possa ser rompido o feitiço da individuação, como pressentimento de uma unidade restabelecida (NIETZSCHE, 1992b, p. 70).
\end{abstract}

Nas mãos de Eurípides a tragédia teria, ao fim, alcançado sua morte: por suicídio, acrescenta Nietzsche. Com a perda de seu lugar no palco helênico restou ao trágico o retorno ao refúgio no místico. Eurípides representa o fim da era titânica no drama trágico grego, o abandono dos elementos dionisíacos em nome daquele realismo criticado antes pelo filósofo. O instante, o chiste, a irreflexão, o capricho, estas são as marcas desta nova etapa da história da tragédia grega que, neste sentido, não se distanciava da contemporânea comédia nova. Os excitantes que moviam a pena de Eurípides eram os pensamentos paradoxais e os afetos ardentes. As personagens do palco não são mais a encarnação de Dionísio, mas são os próprios espectadores levados à cena, a tragédia deixa de revelar aquele caminho para os recônditos mais secretos na natureza, desfalece-se em monótona banalidade. Temos diante de nós o substrato daquele grupo de porcos-espinhos da parábola schopenhaueriana, citada aqui por Nietzsche (NIETZSCHE, 1992b, p. 134), que representa a sociedade em fuga do sofrimento e do tédio e em busca de uma arte de entretenimento - este mal euripidiano é ainda o diagnóstico nietzschiano da arte de seu tempo: a arte como distração, para os exaustos e enfermos, diz o filósofo em A gaia ciência (NIETZSCHE, 2001, p. 117).

E qual seria a inspiração de Eurípides para seu drama não-dionisíaco? Ele mesmo, não enquanto artista, afirma Nietzsche, mas enquanto pensador, e ainda o 
impulso lógico da filosofia socrática: "Quem falava por sua boca, não era Dionísio, tampouco Apolo, porém um demônio de recentíssimo nascimento, chamado Sócrates" (NIETZSCHE, 1992b, p. 79). Ao pessimismo trágico dos gregos se impõe agora o presunçoso otimismo teórico de Sócrates. O socratismo inoculado no drama euripidiano não é, conforme Nietzsche, nenhum impulso artístico: pela sua dissociação ao dionisíaco, ao mito, a cristalização da tendência apolínea em Sócrates (o comedimento e o autoconhecimento délfico) permanece à margem da visão trágica anterior. Chegar ao Ser e corrigi-lo através do pensar: eis a ilusão metafísica da qual Sócrates estava seriamente enfermo. A moralidade da serenojovialidade socrática é o elemento tomado por Nietzsche não só como representativo do declínio do espírito trágico grego como também de todos os valores nobres da civilização Ocidental. "Tudo deve ser inteligível para ser belo", diz a divisa do racionalismo otimista empregada em As Bacantes de Eurípides. Em contrapartida, contra este gélido olho ciclópico do pensamento antidionisíaco de Sócrates, diz Nietzsche:

Também o divino Platão [!] fala, quase sempre com ironia, da faculdade criadora do poeta, na medida em que ela não é discernimento [Einsicht] consciente, e a equipara à aptidão do adivinho e do intérprete de sonhos; posto que o poeta não é capaz de poetar enquanto não ficar inconsciente e nenhuma inteligência residir mais nele (NIETZSCHE, 1992b, p. 83).

A despeito deste enaltecimento nietzschiano, a influência socrática em Platão é denunciada através da colocação da poesia como a ancilla (escrava) da filosofia. Mais do que isto, a própria vida é violentamente esterilizada pelo racionalismo dialético: "Sócrates é o herói dialético no drama platônico" (NIETZSCHE, 1992b, p. 89). Não obstante, conduzindo seu cavalo de tróia ao interior do templo délfico, Nietzsche busca na idéia do Sócrates musicante o modelo de uma crítica destrutiva no próprio seio do otimismo cientificista. Ao Sócrates 
convalescente é revelada esta terrível verdade, contra a qual o mais sábio dos gregos se vê impotente com o chicote de seus silogismos: a razão esbarra neste limite intransponível além do qual só a arte tem acesso livre. "Será que não existe um reino da sabedoria, no qual a lógica está proscrita?" (NIETZSCHE, 1992b, p. 91), pergunta Nietzsche. Tal reino pertence à sabedoria dionisíaca (ou sabedoria trágica), que a prescrição da divindade ("Sócrates, faz música!") pretende revelar. Ainda em O nascimento da tragédia é possível encontrar o elogio, posteriormente rejeitado, à "enorme bravura de Kant e de Schopenhauer" pela "vitória sobre o otimismo oculto na essência da lógica" (NIETZSCHE, 1992b, p. 110) e por terem expressado tão bem a sabedoria dionisíaca através de conceitos.

Nesta obra de juventude, ainda sob influência wagneriana, Nietzsche vislumbrava na música alemã a possibilidade do renascimento da tragédia. Na ópera moderna, entretanto, observa Nietzsche traços desta cultura socrática iniciada entre os gregos: arte de divertimento, opera-se ali o contrabando do moral para o estético - curiosamente, ao exemplificar a cultura trágica em oposição àquela primeira, o filósofo escolhe o budismo (a sociedade alexandrina representaria o socratismo e os helenos representariam a cultura artística, cujo consolo, diferente das duas outras, advém do véu de beleza da arte), o mesmo budismo que antes fora tomado como antidionisíaco. Portanto, ao expor as três ilusões da Vontade, as culturas socrática, artística e trágica, é evidente que este trágico não se refere à tragédia ática: entre Roma (cultura socrático-alexandrina) e Îndia (o budista anseio pelo nada), diz Nietzsche, a Grécia inventou um terceiro caminho. Em meio a este estranhamento, no entanto, pode agora o leitor de $O$ nascimento da tragédia entender a nomeação das Mães do ser citada acima: llusão, Vontade, Dor. Ao tragicismo da inseparabilidade entre Vontade e dor, alia-se este artificioso ato da Vontade, as suas três ilusões: 
A vontade ávida sempre encontra um meio, através de uma ilusão distendida sobre as coisas, de prender à vida as suas criaturas, e de obrigá-las a prosseguir vivendo. A um algema-o o prazer socrático do conhecer e a ilusão de poder curar por seu intermédio a ferida eterna da existência, a outro enreda-o, agitando-se sedutoramente diante de seus olhos, o véu de beleza da arte, àqueloutro, por sua vez, o consolo metafísico de que, sob o turbilhão dos fenômenos, continua fluindo a vida eterna (NIETZSCHE, 1992b, p. 108) ${ }^{40}$.

Ao fim, resta-nos ainda a questão levantada sobre a ruptura entre ética e estética, pois, impregnado do fúnebre perfume de Schopenhauer, como diz Nietzsche em Ecce homo, vemos estranhamente misturados este pensamento dionisíaco da afirmação incondicional da vida com o mesmo niilismo schopenhaueriano tão avidamente combatido posteriormente por ele. No entanto, apesar de se servir da instrumentária conceitual de Schopenhauer, a arte em geral e a tragédia em particular não oferece aquele quietivo exposto no terceiro livro de $O$ mundo: diante de um drama trágico, "essa longa seqüência de efeitos apolíneos não engendrou, apesar de tudo, aquela ditosa persistência em uma contemplação isenta de vontade [grifo nosso]" (NIETZSCHE, 1992b, p. 130). Contrapondo-se à idéia de katharsis já presente em Aristóteles e que também marca a consideração schopenhaueriana da tragédia, sentencia Nietzsche:

Ora são a compaixão e o medo que devem ser impelidos por sérias ocorrências a uma descarga [Entladung] aliviadora, ora devemos sentir-nos exaltados e entusiasmados com a vitória dos bons e nobres princípios, com o sacrifício do herói no sentido de uma consideração moral do mundo (NIETZSCHE, 1992b, p. 132).

\footnotetext{
${ }^{40}$ Semelhante divisão trinária é apresentada por Schopenhauer no quarto Livro de $O$ mundo como as três formas extremas da vida humana (de inspiração védica, a partir de uma leitura do Bhagavad-Gita, o livro sagrado do hinduísmo): 1) vontade enérgica, vida com grandes paixões (Radja-Guna); 2) inteligência liberta do serviço da vontade - gênio (Sattva-Guna); 3) letargia da vontade - tédio (Tama-Guna). Em Sobre a vontade na natureza (1836) estas três formas serão chamadas de as três potências (Kräften) fisiológicas fundamentais: e pode-se perceber aí o filósofo arriscar uma fundamentação dos caráteres dos indivíduos nas funções biológicas do organismo (à maneira aristotélica), e também traçar um paralelo entre estes caráteres e as características sociais de um povo (à maneira platônica): assim, da primazia da produtividade (tecido celular) no ser orgânico se tem um caráter fleugmático (Beócios); da irritabilidade (músculos) advém a aptidão para esforços corporais (Espartanos); e da sensibilidade (nervos) - o cérebro é o centro do sistema nervoso - tem-se o indivíduo de gênio (Atenienses) (SCHOPENHAUER, 1982, p. 78).
} 
Munido desta convicção o filósofo percorreu a tragédia grega, procurando mostrar, conforme as palavras não menos críticas de $A$ Gaia ciência, que os gregos "tudo fizeram para contrariar o efeito elementar das imagens que provocam temor e compaixão: pois eles não queriam temor e compaixão [grifo do autor]" (NIETZSCHE, 2001, p. 108). Destarte, com a tragédia os helenos pretendiam desafogar a alma dos excessos (medo, compaixão, vingança etc.) que promovem qualquer tipo de declínio da vontade - somente neste sentido podemos compreender a estranheza causada pela referência de Nietzsche à música como purificadora e calmante (NIETZSCHE, 2001, p. 112) ${ }^{41}$. Mais ainda: a tragédia nasceu de uma "necessidade de atribuir e incorporar dignidade ao delito" (NIETZSCHE, 2001, p. 153). Com o olhar atento, pode-se perceber que "existem alturas da alma, de onde mesmo a tragédia deixa de ser trágica", como o faz Nietzsche em Além do bem e do mal (NIETZSCHE, 1992a, p. 37), ou seja: a compaixão trágica dos gregos, estas crianças leoninas (NIETZSCHE, 1998, p. 82), consistiu na sublimação e sutilização do prazer da crueldade (NIETZSCHE, 1998, p. 57).

Numa carta ao amigo Overbeck (sobre o rompimento com Lou Salomé) confirma Nietzsche sua crítica ao fundamento da moral schopenhaueriana: "Compaixão, meu caro amigo, é uma espécie de inferno, diga o que quiserem os adeptos de Schopenhauer" (ANDREAS-SALOMÉ, 1992, p. 15).

Tendo em vista que "significado moral do mundo" e "metafísica" se tornam, a partir da fase intermediária de seu pensamento, conceitos intercambiáveis, podemos afirmar (conforme o parágrafo 215 de Humano, demasiado humano) que ali a música não fala mais de Vontade, de coisa em si, nem tampouco é profunda e significativa - apesar de ser ainda identificada com a vida. Neste sentido, criticando

\footnotetext{
${ }^{41}$ Na Genealogia da moral esta idéia do "efeito calmador da vontade" [Willen-calmierende] pregada pela estética schopenhaueriana é veemente atacada, com o apoio de Stendhal, para quem toda experiência musical é extremamente interessada (NIETZSCHE, 1998, p. 95).
} 
a conversão wagneriana ao pensamento de Schopenhauer na terceira dissertação

da Genealogia da moral, diz Nietzsche:

\begin{abstract}
Wagner modificou rudemente seu juízo sobre o valor e o status da música mesma: que the importava que até então tivesse feito dela um meio, um medium, uma "mulher" que para crescer necessitava absolutamente de um fim, um homem - isto é, o drama! Compreendeu de imediato que com a teoria e a inovação de Schopenhauer podia-se fazer mais in majorem musicae gloriam - isto é, com a soberania da música, tal como Schopenhauer a compreendia: a música separada de todas as demais artes, a arte independente em si, não, como as outras, oferecendo imagens da fenomenalidade, mas falando a linguagem da vontade mesma, diretamente do "abismo", como sua revelação mais própria, mais primordial, mais imediata. Com essa extraordinária elevação do valor da música, que parecia decorrer da filosofia schopenhaueriana, também a cotação do músico subiu prodigiosamente: tornou-se um oráculo, um sacerdote, mais que um sacerdote, uma espécie de porta-voz do "em-si" das coisas, esse ventríloquo de Deus - falava metafísica: como admirar que um dia falasse em ideais ascéticos?... (NIETZSCHE, 1998, p. 92-3).
\end{abstract}

Em A gaia ciência lemos o mais explícito mea culpa de sua adesão juvenil ao romantismo: "interpretei a música alemã como se exprimisse uma potência dionisíaca da alma alemã [...] vê-se que então compreendi mal, tanto no pessimismo filosófico como na música alemã o que constitui seu caráter peculiar - o seu romantismo" (NIETZSCHE, 2001, p. 272). 


\section{NIILISMO PASSIVO VERSUS NIILISMO ATIVO}

Em Ecce homo Nietzsche mostra em que termos pode ser descrita a nova senda trilhada pelo seu pensamento a partir de Humano, demasiado humano, a saber, como o congelamento do ideal metafísico que ele mesmo abraçara em suas obras anteriores (incluindo suas observações sobre Schopenhauer e o ensino da filosofia da terceira Extemporânea): "Aqui, por exemplo, congela 'o santo'; pouco adiante congela 'o gênio'; sob um espesso sincelo congela 'o herói'; por fim congela 'a fé', a chamada 'convicção', também a 'compaixão' esfria consideravelmente - em quase toda parte congela 'a coisa em si' " (NIETZSCHE, 1995, p. 73). "De súbito ficou para mim terrivelmente claro quanto tempo já fora desperdiçado" (NIETZSCHE, 1995, p. 74), diz ele a respeito do wagnerianismo e dos anos dedicados à filologia; inicia-se assim a construção de sua filosofia terrena, do fenomenismo com o qual o filósofo procuraria desmontar o pesado edifício filosófico da metafísica tradicional: "o que é agora, para mim, aparência?", indaga ele, "verdadeiramente, não é o oposto de alguma essência - que posso eu enunciar de qualquer essência, que não os predicados de sua aparência?" (NIETZSCHE, 2001, p. 92).

Não obstante, em alguns momentos da fase posterior de seu pensamento este fenomenismo parece sofrer algumas recaídas (o que levará a uma certa suspeita, entre alguns intérpretes de Nietzsche, desta ruptura com a velha metafísica). Lemos em Além do bem e do mal: 
minha tese - ; supondo que se pudesse reconduzir todas as funções orgânicas a essa vontade de poder, e nela se encontrasse também a solução para o problema da geração e nutrição - é um só problema - , então se obteria o direito de definir toda força atuante, inequivocamente, como vontade de poder. O mundo visto de dentro [grifo nosso], o mundo definido e designado conforme o seu "caráter inteligível" - seria justamente "vontade de poder", e nada mais (NIETZSCHE, 1992a, p. 43).

Contrapondo-se à tese do platonismo invertido em Nietzsche ${ }^{42}$, Scarlett Marton procura mostrar que o pensamento nietzschiano "não residiria na tentativa de levar a metafísica até suas últimas conseqüências [Heidegger] nem no ensaio de inaugurar novas técnicas de interpretação [Foucault]" (MARTON, 1990, p. 13). Tratase antes de um projeto de uma filosofia da natureza, uma cosmologia. Para ela, a vontade de potência (como opta traduzir a Wille zur Macht), apoiada em dados científicos, deve constituir a base desta cosmologia. A partir de uma perspectiva semelhante, Wolfgang Müller-Lauter procura demonstrar que quando Nietzsche fala "num mundo cuja essência [Essenz] é vontade de poder" (NIETZSCHE, 1992a, p. 86), esta essência não pode ser compreendida como unidade transcendente, como queria Heidegger, mas como unidade imanente. Para ele, quando Nietzsche fala na vontade de potência, no mundo, na essência, etc., devemos entender tratar-se na verdade de vontades de poder: forças essenciais em perpétua luta entre si, sem qualquer finalidade a não ser o anseio por domínio, por aumento de poder. E só se pode falar em unidade enquanto organização destas forças, acomodação e ao mesmo tempo superação de si $^{43}$ com o único objetivo de aumentar o domínio sobre vontades mais fracas. Nietzsche representa então uma ruptura com o dualismo cosmológico que marca o pensamento clássico: "por detrás das fachadas, sempre

\footnotetext{
${ }^{42}$ Eduardo Brandão em sua tese sobre o conceito de matéria em Schopenhauer, critica - a partir da análise do aristotelismo presente na noção de Idéia empregada por Schopenhauer - a negligência de Heidegger em relação à metafísica da natureza schopenhaueriana, mostrando que "é justamente sobre este ocultamento de Schopenhauer que se fortalece o lugar que Heidegger atribui a Nietzsche na história da metafísica". E conclui: "Com isso, queremos dizer que o modo como Heidegger encara a filosofia de Schopenhauer facilita a classificação de Nietzsche como o 'último metafísico do Ocidente', na medida em que não ressalta o projeto de Schopenhauer de decifração do enigma do mundo, considerado a partir da metafísica da natureza, como uma postura moral que Nietzsche talvez critique" (BRANDÃO, 2002, p. 268).

${ }^{43}$ Nas palavras de Marton: "coordenação ou desagregação entre impulsos" (MARTON, 1990, p.34).
} 
de novo erigidas por ele, a metafísica desmorona, em conseqüência de seu incessante perguntar" (MÜLLER-LAUTER, 1997, p. 53). Estas vontades de poder, ou forças, também podem ser chamadas de quanta (terminologia empregada por Nietzsche em alguns póstumos). Cada uma delas já é uma unidade constituída por outras vontades mais fracas, outros quanta. A unidade dos quanta, desde que se entenda esta unidade como continuamente mutável, Nietzsche chama de quantum. Do mesmo modo os quantum são unidades instáveis: um pode se tornar dois e de dois se formar um. "Um quantum de força", diz ele na Genealogia da moral (a respeito da inevitabilidade das ações imorais naqueles em que há a abundância de força), "equivale a um mesmo quantum de impulso, vontade, atividade" (NIETZSCHE, 1998, p. 36). Não há uma unidade derradeira, um quantum último ao qual se poderia chegar (daí a crítica de Nietzsche ao atomismo). Podemos então nos referir à Vontade de poder como singularidade somente enquanto: 1) Qualidade única, não substancializada, de todos os seres; 2) "Determinações universais com as quais freqüentemente multiplicidades são reunidas em âmbitos"; e 3) Caráter de distinção entre outras vontades.

Não se trata aqui, ainda segundo Müller-Lauter, de formas ou unidades Ideais, como o seria, por exemplo, a idéia de humanidade, repudiada por Nietzsche, mas antes de organizações de vontades de poder, de quanta - que no conceito de sociedade, por exemplo, aparece numa configuração maior, assim como o homem é uma configuração menor e o protoplasma é uma menor ainda.

A partir disto, podemos então indagar: como poderia então qualquer tipo de conhecimento ter a pretensão de validade, num mundo onde predomina o acaso, onde não há nunca uma unidade permanente tanto daquilo que conhece quanto do que é conhecido? Contra o positivismo, explica Müller-Lauter, Nietzsche diria que "não há fatos, só interpretações" (MÜLLER-LAUTER, 1997, p. 125). Entretanto, se 
toda teoria é, deste modo, mera interpretação, "em face da fundamental relatividade de todo explicar-o-mundo, o que poderia ser aduzido em favor da 'verdade' da interpretação de Nietzsche?" (MÜLLER-LAUTER, 1997, p. 126). O novo critério de verdade nietzschiano visará agora as explicações que procuram a intensificação do poder e não mais simplesmente a conservação da vida.

Sendo assim, contra a metafísica do corpo de Schopenhauer e a idéia de que nada pode melhor ser conhecido do que nós mesmos (pois o corpo é o objeto imediato do conhecimento, tornando-se ele a chave de acesso ao mundo em si), Nietzsche declara, já em Aurora (§ 116) que o mundo interno não é menos inacessível do que o externo ${ }^{44}$. Sentença aparentemente simples, mas que revela o quão distante estendem-se as raízes de seu perspectivismo: "este é o verdadeiro fenomenalismo [Phänomenalismus] e perspectivismo [Perspektivismus], como eu o entendo [grifo do autor]", lê-se no $§ 354$ de A gaia ciência - cabe observar, a propósito, a importante influência desta assertiva nas teorias da interpretação dos hermeneutas contemporâneos (de fato, para Nietzsche a própria verdade nada mais é que o produto de um consenso $)^{45}$. Schopenhauer, ao apresentar a tese da simplicidade e da imediaticidade do querer, estaria ainda, segundo Nietzsche, algemado à psicologia de uma antiga religiosidade. Munido de uma radical suspeita em relação ao conhece-te a ti mesmo, Nietzsche quer revelar que a consciência, no seu retorno a si mesma, traz consigo justamente aquilo que não pertence ao indivíduo, mas ao que pertence ao gênio da espécie, ao que ele chamou de instinto gregário, tendo em vista que a consciência (parte menor, pior, mais artificial do ser

\footnotetext{
44 "Cada qual é o mais distante de si mesmo [...] As palavras 'conhece-te a ti mesmo' são, na boca de um deus e dirigidas aos homens, quase uma maldade" (NIETZSCHE, 2001, p. 222).

${ }^{45} \mathrm{E}$ se insistíssemos em que também a própria teoria nietzschiana sobre a verdade é apenas uma interpretação? Resposta de Nietzsche: "Acontecendo de também isto ser apenas interpretação - e vocês se apressarão em objetar isso, não? - bem, tanto melhor!" (NIETZSCHE, 1992a, p. 28-9).
} 
humano) ocorre em palavras ${ }^{46}$. A gramática (metafísica do povo) é incapaz de estabelecer distinções como a do fenômeno e coisa em si. O mundo interior é até mesmo o mais difícil de ser conhecido, pois sendo o mais familiar, habitual, é também o tipo de conhecimento menos problematizável. No mesmo sentido, um dos principais objetos em torno dos quais gravita toda discussão sobre a moral, a liberdade da vontade ${ }^{47}$, é criticada como um anseio por uma causa sui (NIETZSCHE, 1992a, p. 16) - o oposto também não passa de ficção convencional, de um abuso dos conceitos de causa e efeito: o cativo arbítrio (unfreier Wille). A própria idéia de sujeito da ação moral deve ser colocada entre parênteses: "não existe um tal substrato; não existe 'ser' por trás do fazer, do atuar, do devir; o 'agente' é uma ficção acrescentada à ação - a ação é tudo" (NIETZSCHE, 1998, p. 36).

Isto posto, depois de Humano, demasiado humano, é dado início ao ataque a toda tentativa de redução da vida ao significado moral, em outras palavras, à necessidade metafísica do homem schopenhaueriana. Trata-se de "bailar sobre a moral" (como diz Nietzsche em Ecce homo, sintetizando o intento de sua Gaia ciência), de rebaixá-la ao empírico - tarefa já assumida de certa forma em sua primeira publicação, conforme lemos no prefácio tardio de A origem da tragédia mostrando agora que "o homem moral não está mais próximo ao mundo inteligível do que o homem físico - porque não existe mundo inteligível" (NIETZSCHE, 1995, p. 77). A tal necessidade metafísica de Schopenhauer seria então uma demonstração de que a sua época não estava cientificamente forte, que a época das filosofias

\footnotetext{
${ }^{46}$ Eis a explicação da superficialidade de Descartes da qual fala Nietzsche (NIETZSCHE, 1992a, p. 91). Apontando para a familiaridade entre a história da moral e a da linguagem, Nietzsche chega a propor um concurso acadêmico sobre o tema (talvez uma alusão aos concursos dos quais surgiram os ensaios schopenhauerianos sobre a moral). Eis a questão apresentada, com um certo tom de polêmica nietzschiana, na Genealogia da moral: "Que indicações fornece a ciência da linguagem, em especial a pesquisa etimológica, para a história da evolução dos conceitos morais?" (NIETZSCHE, 1998, p. 45).

${ }^{47}$ Freiheit des Willens é também traduzido por Paulo César de Souza como "livro arbítrio", o mesmo equívoco do tradutor francês do ensaio Sobre a liberdade da vontade de Schopenhauer.
} 
pessimistas é também a da mais refinada e afeminada sensibilidade (suscetibilidade à dor) e que, a despeito das críticas deste aos dogmas cristãos, a visão de mundo cristã medieval pôde ser reintroduzida em sua doutrina. É preciso, pois mostrar que a necessidade metafísica não engendra as religiões, mas, pelo contrário, fomos habituados por estas à crença em um outro mundo. Deus está morto, sentencia Nietzsche, mas sua sombra ainda paira sobre nós ${ }^{48}$. O próximo passo a ser dado já se anuncia em sua própria obra: "eu, que primeiramente atei o nó da moral na existência e depois o apertei de forma tal que somente um deus o poderá desatar" (NIETZSCHE, 2001, p. 161). Mais ainda, trata-se de mostrar que nos fenômenos não existe de fato nenhuma moral, mas "apenas uma interpretação moral dos fenômenos" (NIETZSCHE, 1992a, p. 73).

É necessário, assim, atacar o ponto central em torno do qual toda moralidade foi erigida: o altruísmo, a ação não-egoísta. A maldade não tem como objetivo o bem alheio, do mesmo modo que a compaixão não repousa sobre o prazer do outro, mas ambos se explicam pelo prazer próprio oferecido ao sujeito da ação. Nenhuma ação é desinteressada, como queria Schopenhauer: pelo contrário, afirma Nietzsche, o egoísmo está presente até mesmo naquelas atitudes de máxima valoração moral. Não se age como individuum, mas como dividuum, diz o filósofo em Humano, demasiado humano ( $§ 57$ ), referindo-se à moral como autocisão, como desvalorização deste mundo em nome de um mundo ideal. Quanto à compaixão, dois tipos de prazeres são destacados: o da emoção (Nietzsche pensa aqui na compaixão da tragédia) e o do contentamento no exercício do poder, do domínio do sofredor por parte do compassivo. Por trás de toda vontade de trágico, de

\footnotetext{
${ }^{48}$ Esta sombra (podemos notar com certa estranheza) se estende a lugares onde menos imaginamos: nos vícios de linguagem, por exemplo. Neste caso, nem o próprio Nietzsche, o Anticristão, conseguiu se desvencilhar desta sombra, como vemos em Além do bem e do mal quando critica o patriotismo germânico: "algo que, graças a Deus [Gott sei Dank], estamos a ponto de nos livrar com sucesso" (NIETZSCHE, 1992a, p. 151).
} 
pessimismo, esconde-se uma coragem, um orgulho, uma busca por um grande inimigo.

Nietzsche pretende assim despir a "colorida pele de leopardo" da metafísica para denunciar o moralista por trás dela (conforme parágrafo 33 das Miscelâneas de opiniões e sentenças). Ainda nesta obra o filósofo apresentará sua contraposição à moral da compaixão (Mitleid - sofrer-com) cunhando o neologismo Mitfreud (contentamento-com): privilégio dos "animais superiores" (§ 62) ou "homens de alta linhagem", diz ele em Além do bem e do mal (NIETZSCHE, 1992a, p. 37).

\section{A SAÚDE DA FILOSOFIA}

Em A Gaia ciência o abandono daquele pessimismo metafísico schopenhaueriano que impregnava o filósofo no início de sua carreira é considerado uma cura de uma doença, da qual a modernidade estaria ainda seriamente enferma:

Toda filosofia que põe a paz acima da guerra, toda ética que apreende negativamente o conceito de felicidade, toda metafísica que conhece um finale, um estado final de qualquer espécie, todo anseio predominantemente estético ou religioso por um Além, Ao-lado, Acima, Fora, permitem perguntar se não foi a doença que inspirou o filósofo (NIETZSCHE, 2001, p. 11).

A moral da renúncia de si, da resignação, da fuga budista em direção ao Nada (numa palavra: o niilismo), constitui a doença da qual o dizer Sim de Zaratustra será a cura. O pessimismo pode ser mesmo encarado como uma destas doenças de inverno alemão, ocasionada, diz ele, por um erro de dieta, como o 
excesso de arroz entre os indianos ou de álcool na Europa: "a idade média foi o envenenamento da Europa pelo álcool" (NIETZSCHE, 2001, p. 152) ${ }^{49}$. Causas fisiológicas podem ainda ser constatadas neste mal-estar do ressentimento: "enfermidade do nervus sympathicus, numa anormal secreção da bilis, numa pobreza de sulfato e fosfato de potássio no sangue, em estados de tensão do baixo ventre que impedem a circulação do sangue, ou ainda numa degeneração dos ovários etc." (NIETZSCHE, 1998, p. 117). Para aqueles que sentem a vida mesma como uma doença, a despedida dela Ihes caem como uma cura; é nestes termos que Nietzsche interpreta o pessimismo presente na última frase de Sócrates em seu leito de morte - "devo um galo a Asclépio": o deus da medicina é aqui invocado como o responsável pela libertação da enfermidade que seria o próprio viver. Entre os gregos ou entre os modernos, os imperativos morais são problemas que exigem solução médica (NIETZSCHE, 1998, p. 46).

A moral é um produto da debilidade da vontade, do impulso de conservação da espécie, daquilo que será denominado como o instinto de rebanho juntamente com seus produtos: a idéia de humanidade (esta velha medonha, proclama Nietzsche), a democracia (uma herança cristã) etc. No entanto, Nietzsche procurará mostrar em toda a sua obra que também os chamados maus impulsos são apropriados e mesmo indispensáveis à conservação da espécie, diferindo-se dos outros tão somente quanto à funcionalidade - nas obras da maturidade será apresentada a diferenciação entre a moral dos fracos, dos escravos e a moral dos fortes (em A gaia ciência, no entanto, a própria moral chega mesmo a ser proibida). Em suma, a moral atua erradamente no caminho inverso ao da alquimia, diz o

\footnotetext{
${ }^{49}$ Na Encíclica do papa Bento XVI de dezembro de 2005, intitulada Deus caritas est, o líder católico faz uma referência (para tentar refutá-lo) ao seu compatriota Nietzsche, a respeito desta embriaguez: "Segundo Friedrich Nietzsche, o cristianismo teria dado veneno a beber ao Eros, que, embora não tivesse morrido, daí teria recebido o impulso para degenerar em vício. Este filósofo alemão exprimia assim uma sensação muito generalizada: com os seus mandamentos e proibições, a Igreja não nos torna porventura amarga a coisa mais bela da vida? Porventura não assinala ela proibições precisamente onde a alegria, preparada para nós pelo Criador, nos oferece uma felicidade que nos faz pressentir algo do Divino?”.
} 
filósofo: promove a desvalorização do que é de fato valioso. Em ambos os casos predomina o mesmo sentimento de poder (Machtgefühl) - declara o filósofo em $A$ gaia ciência (NIETZSCHE, 2001, p. 64) - e a necessidade de domínio, pois também na compaixão procura-se apossar do sofredor (a presa fácil) ${ }^{50}$, o amor ao próximo nada mais é que a ânsia por nova propriedade (as forças inferiores também querem dominar), do mesmo modo que o amor sexual também o é: em suma, permanecemos ainda diante das mais refinadas formas de egoísmo. Temos então aqui os sinais daquilo que será a Vontade de poder (Wille zur Macht), conceito erigido por Nietzsche em contraposição à Vontade de viver (Wille zum Leben) de Schopenhauer. Conforme as palavras oraculares de Zaratustra:

Onde encontrei vida, encontrei vontade de poder; e ainda na vontade do servo encontrei a vontade de ser senhor. Que o mais fraco sirva o mais forte, a isto o induz a sua vontade, que quer dominar outros mais fracos [...] E onde há sacrifícios serviços prestados e olhares amorosos: ali, também, há vontade de ser senhor. Por caminhos oblíquos, introduz-se o mais fraco na fortaleza e até no coração do mais forte - e, ali, furta poder. (NIETZSCHE, 2003, p. 145)

Escutando a voz da própria vida, Zaratustra recebe esta confidência:

Certamente não encontrou a verdade aquele que the desfechou a expressão "vontade de existência" [Wille zum leben]: essa vontade - não existe! Porque: o que não existe não pode querer; mas, o que é existente, como poderia ainda querer existência! Onde há vida também há vontade: mas não vontade de vida, senão - é o que te ensino - vontade de poder! (NIETZSCHE, 2003, p. 146)

Vê-se, pois que a conservação da vida não é anterior ao sentimento de expansão de poder, pelo contrário, para mostrar que na natureza reina a abundância e não a indigência, Nietzsche procura mostrar que mesmo em formas ínfimas de

\footnotetext{
${ }^{50}$ Diante do fato de que "uma vontade de poder se assenhoreou de algo menos poderoso e lhe imprimiu o sentido de uma função" (NIETZSCHE, 1998, p. 66), poder-se-ia perguntar: "é virtuoso que uma célula se transforme numa função [Function] de uma outra célula mais forte? Ela tem de fazê-lo. E é mau que a mais forte a assimile? Ela tem de fazê-lo também" (NIETZSCHE, 2001, p. 143).
} 
organismos (como em toda força cósmica) a satisfação não detém a busca pelo acúmulo de alimento ${ }^{51}$, numa "assimilação insaciável" (MARTON, 1990, p. 39).

Entrementes, Nietzsche ainda acredita numa forma de relação entre dois indivíduos na qual se pode realmente notar uma forma elevada de manifestação de poder. Na moral dos senhores, dos homens nobres (entre os quais a figura de Napoleão seria seu representante mais fiel), "pode entrar a compaixão, e coisas do gênero" (NIETZSCHE, 1992a, p. 174):

\begin{abstract}
Existe no mundo, aqui e ali, uma espécie de continuação do amor, na qual a cobiçosa ânsia que duas pessoas têm pela outra deu lugar a um novo desejo e cobiça, a uma elevada sede conjunta de um ideal acima delas: mas quem conhece tal amor? Quem o experimentou? Seu verdadeiro nome é amizade (NIETZSCHE, 2001, p. 66-7) ${ }^{52}$.
\end{abstract}

A crítica de Nietzsche parece então em alguns momentos poupar a moral e a compaixão (a despeito da censura radical estabelecida ao mesmo tempo) desde que praticados pelos nobres de espíritos:

\begin{abstract}
Um homem que diz: "Isso me agrada, vou me apropriar disso, protegê-lo e defendê-lo contra todos"; um homem que pode conduzir uma causa, executar uma decisão, ser fiel a um pensamento, reter uma mulher, castigar e abater um insolente; um homem que tem sua ira e sua espada, a quem os fracos, aflitos, sofredores e também os animais se achegam com gosto e pertencem por natureza; em suma, um homem que é senhor por natureza - se um tal homem tem compaixão, esta compaixão tem valor! Mas que importa a compaixão dos que padecem! Ou daqueles que inclusive pregam a compaixão! (NIETZSCHE, 1992a, p. 76).
\end{abstract}

Deve-se mesmo notar que a atitude dos fortes, tudo aquilo que foi de fato a regra na história da conservação da espécie foi desvalorizado pela moral em nome de exceções, as atitudes dos débeis de vontade. Nietzsche se coloca assim como o advogado da regra, daquilo que, segundo ele, realmente dera colorido à vida (amor, cupidez, inveja, cobiça, maldade e outras paixões deste tipo, excluídas pela história

\footnotetext{
51 "A luta pela existência é apenas uma exceção, uma temporária restrição da vontade de vida; a luta grande e pequena gira sempre em torno da preponderância, de crescimento e expansão, de poder, conforme a vontade de poder [Wille zur Macht], que é justamente vontade de vida [Wille des Lebens]" (NIETZSCHE, 2001, p. 244).

52 "Toda companhia é má, exceto a companhia dos iguais" (NIETZSCHE, 1992a, p. 33).
} 
da moral): "Tudo o que é habitual, próximo e indispensável, em suma, aquilo que mais conserva a espécie e que constitui a regra na humanidade até agora, foi injustamente julgado e, no seu conjunto, caluniado, em favor de exceções" $\left(\right.$ NIETZSCHE, 2001, p. 93) ${ }^{53}$.

Ademais, não se pode deixar de denunciar o efeito castrador da moral - o Moral-Castratismus, como lemos num fragmento do outono de 1887 (NIETZSCHE, 1980, XII, p. 548). A função dada por Schopenhauer ao Estado-focinheira, Nietzsche atribui também à própria moral: a virtude é um instrumento usado para domesticar o animal de rapina que é o homem, para torná-lo desimportante e inofensivo frente à sociedade. Que seja aqui também incluída a crítica à idéia de um caráter imutável, nocivo à dinâmica mutável do conhecimento (em oposição ao ponto central da Ética schopenhaueriana). Em conseqüência, "esse grande antídoto para o tédio e as paixões [a moral] torna embotados os sentidos e faz o espírito refratário a estímulos novos" (NIETZSCHE, 2001, p. 71). Enquanto Schopenhauer descreve o ato piedoso como o encontro da via correta, do bom caminho, Nietzsche tende a vê-lo como um desvio ou, melhor ainda, como um extravio. Para nos mantermos firmes na espinhosa senda traçada pela vida é preciso ter força para resistir à oculta sedução da compaixão. Conceitualmente percebemos também que a compaixão, enquanto "agradável movimento do impulso de apropriação, à vista do mais fraco" (NIETZSCHE, 2001, p. 143), abriga uma contradição insuperável: como castração dos impulsos, significa uma diminuição da força, portanto uma debilitação, um dano; sendo assim, o pensamento desinteressado deveria evitar este sofrimento infligido contra o próprio compadecente! Por este motivo declara Nietzsche ser o egoísmo conseqüente e sem sentimento de culpa a única atitude realmente dotada de valor nobre. Por outro lado, contra o socialismo deve-se apresentar a mais rigorosa

\footnotetext{
${ }^{53}$ Numa outra passagem Nietzsche inverte a classificação tomando a compaixão como a representante da regra: "Nós, os outros, somos a exceção e o perigo..." (NIETZSCHE, 2001, p. 105).
} 
aristocracia que respeite a hierarquia natural entre os homens (o próprio organismo é disposto hierarquicamente, diz ele na Genealogia da moral). É natural pois que a idéia da ruptura do principium individuationis, conceito schopenhaueriano de suma importância em $O$ nascimento da tragédia, seja agora duramente criticado por Nietzsche como um dos absurdos da filosofia schopenhaueriana, juntamente com a tese da unidade da Vontade.

A aceitação amorosa (Amor fatı) do sofrimento e da violência inerente à vida e seu permanente retorno, o desprezo de qualquer escapatória em direção a um Além-mundo: eis o segredo da vivência nobre descrita por Nietzsche, que se apresenta agora em sua formulação mais clara: Noth ist nöthig! (Aflição é necessária) (NIETZSCHE, 2001, p. 93). O indivíduo capaz desta atitude afirmadora é o representante de uma nova raça de homens: o Super-homem ${ }^{54}$. Este deve ser aquele capaz de afirmar: "no mais fundo de minha alma sinto-me grato a toda a minha doença e desgraça e a tudo imperfeito em mim, pois tais coisas me deixam muitas portas para escapar aos hábitos duradouros" (NIETZSCHE, 2001, p. 200). A impiedade, a vontade ou impulso para infligir dores, também deve ser um caráter desta vivência, indiferente ao que prega a moral: "sim, mentira é a palavra certa: eles bem sabiam da rica felicidade desse tipo de gente, mas impuseram silêncio sobre isso, porque refutava sua teoria de que a felicidade surge apenas com a destruição da paixão e o silenciar da vontade" (NIETZSCHE, 2001, p. 216-17). Cabe a estes impiedosos, a estes espíritos livres que dançam à beira do abismo, a criação das novas tábuas de valores, "mas quem é forte o bastante para isso?" (NIETZSCHE, 1998, p. 84).

Do mesmo modo todo finalismo ou antropomorfismo na natureza deve ser encarado como uma ilusão, resquícios do dogmatismo teológico, ainda perceptível

\footnotetext{
${ }^{54}$ Ou Além-do-homem (Übermensch): conceito que tem sua primeira aparição no § 143 de A gaia ciência.
} 
na ciência moderna (o matematismo da natureza seria um exemplo) - como todo impulso à verdade, tem sua explicação última na conservação da vida, da espécie ${ }^{55}$. O caos seria o único caráter inerente ao mundo, toda logicidade tem origem no ilógico e não o contrário. Ao invés do milenar par conceitual causa-efeito para pensar a dinâmica do mundo, Nietzsche propõe a tese de um continuum a determinar a dinâmica das coisas. A causa da ação resume-se a "um quantum de energia represada, esperando ser utilizada de alguma forma" (NIETZSCHE, 2001, p. 262). Não há um mundo escondido por detrás do vir-a-ser, uma realidade fora da caverna platônica, "aperfeiçoamos a imagem do devir, mas não fomos além dessa imagem, não vimos o que há por trás dela" (NIETZSCHE, 2001, p. 140). É necessário pois desdivinizar a natureza e o homem.

Uma das críticas de Nietzsche ao antropomorfismo da natureza merece especial atenção, pois mostra que em muitos momentos a Vontade schopenhaueriana é interpretada por ele como um equivalente da vontade racional rejeitada pelo próprio Schopenhauer, o que conduziria, erroneamente, à imagem deste como um partidário da idéia do livre arbítrio. Sabemos que em $A$ gaia ciência o filósofo ainda não chegara à formulação de sua Vontade de poder tal como encontramos em Assim falou Zaratustra, o que nos permite, até certo ponto, compreender a crítica a Schopenhauer por ter suposto que "todo existente não passa de algo querente" (NIETZSCHE, 2001, p. 150), sendo que em Zaratustra vida e vontade serão intimamente relacionadas. No entanto, as três teses oferecidas contra este tornam patente ainda a interpretação da Vontade schopenhaueriana como uma espécie de vontade deliberativa transposta para a natureza, algo bem

\footnotetext{
55 " 'Vontade de conhecer a verdade' chamais vós, os mais sábios dentre os sábios, àquilo que vos impele e inflama?", pergunta Zaratustra, "vontade de que todo o existente possa ser pensado: assim chamo eu à vossa vontade!" (NIETZSCHE, 2003, p. 143).
} 
distante, como sabemos, daquilo designado por este conceito na obra do autor de $O$ mundo como vontade e representação. Eis as teses:

\begin{abstract}
Primeira: para que surja a vontade, é necessária antes uma idéia de prazer e desprazer. Segunda: o fato de um estímulo veemente ser sentido como prazer ou desprazer está ligado ao intelecto interpretante, que, é certo, em geral trabalha nisso de modo inconsciente para nós; e o mesmo estímulo pode ser interpretado como prazer ou desprazer. Terceira: apenas nos seres inteligentes há prazer, desprazer e vontade; a imensa maioria dos organismos não tem nada disso (NIETZSCHE, 2001, p. 150).
\end{abstract}

De qualquer modo, despidos da ilusão metafísica de um mundo divinizado estamos ainda à mercê de outro perigo: a substituição de uma metafísica religiosa por uma metafísica laica. A origem disto está na sensação de vazio e incômodo que advém do aniquilamento daquela base oferecida pela religião, do olhar de horror a este mundo desdivinizado e a necessidade de um outro refúgio - tem-se aí (já em $A$ gaia ciência) a idéia que será tenazmente ligada ao conceito de niilismo (o que se torna mais incisivo nos fragmentos que formariam a obra Vontade de poder). De fato, com o anúncio da morte de Deus no $\S 125$ de $A$ gaia ciência - feito pelo homem louco: uma clara alusão à lanterna de Diógenes, o cínico - Nietzsche prenuncia os dois estados de espíritos que serão rotulados, em seus últimos escritos, como as duas formas principais do niilismo: o passivo (pessimismo europeu ou a fuga budista para o nada em razão da morte de Deus) e o ativo (a negação dos resquícios metafísicos da modernidade e a afirmação do eterno retorno). Diz o homem louco com a lanterna no mercado:

Que fizemos nós ao desterrar a terra do seu sol? Para onde se move ela agora? Para onde nos movemos nós? Para longe de todos os sóis? Não caímos continuamente? Para trás, para os lados, para a frente, em todas as direções? Existem ainda "em cima" e "embaixo"? Não vagamos como que através de um nada infinito? [...] Não deveríamos nós mesmos nos tornar deuses, para ao menos parecer dignos dele? (NIETZSCHE, 2001, p. 148). 
Enquanto atitude negadora do homem e do mundo, serão pois alinhadas ao pessimismo moderno de Schopenhauer duas tradições antigas: o budismo e o cristianismo - o título de uma seção da idealizada obra Vontade de poder indica bem este fato: "Niilismo de Schopenhauer: conseqüência do ideal teísta cristão (NIETZSCHE, 1980, XII, p. 40). A partir deste modelo o filósofo identifica outras atitudes decadentes no decorrer da história, como o estoicismo e, principalmente, o epicurismo. À antiga veneração religiosa se contrapõe agora uma outra alternativa: '"Ou suprimir suas venerações ou - a si mesmos!' Esta seria o niilismo; mas aquela não seria também - niilismo?" (NIETZSCHE, 2001, p. 240). Ambos seriam sintomas de um adoecimento da vontade, um evento europeu (e não alemão) do qual Schopenhauer seria seu porta-voz.

Ao invés da fuga para o nada, Nietzsche propõe uma vivência tornada uma cotidiana experimentação científica, isenta de todo resquício de religiosidade. "Viva a física!", brada o filósofo em A gaia ciência (NIETZSCHE, 2001, p. 225) - não esquecendo que também ela não passa de uma interpretação e disposição do mundo, como nos lembrarão as palavras mais contidas de Além do bem e do mal (NIETZSCHE, 1992a, p. 20) ${ }^{56}$. O conhecimento não é para ele um leito de repouso, mas um mundo de perigos e vitórias, em que a vida é sentida como desejável e misteriosa. A "gaia ciência" de Nietzsche, a menos estóica possível, revela-se como causadora de felicidade não menos que causadora da dor, sabe que ambas andam juntas. Não procura tornar o homem mais frio e, consequentemente, menos suscetível à dor. Contrapõe assim o espírito, a jovialidade e a inventividade à seriedade do racionalismo socrático, do homem do conhecimento (o termo também

\footnotetext{
${ }^{56}$ A própria ciência como um todo aparece na Genealogia da moral como uma forma nobre de ascetismo (NIETZSCHE, 1998, p. 137).
} 
é usado ocasionalmente num sentido não pejorativo) ${ }^{57}$. A vontade de verdade também um dos principais pecados schopenhauerianos, apontados já na terceira Extemporânea - impele a ciência de volta ao campo da moralidade e à fuga da vida. No anseio positivista pelo apoio sólido, pela fundamentação da certeza, vemos o mesmo temor do cansaço pessimista, o mesmo instinto de fraqueza.

O eterno retorno, o circulus vitiosos deus (deus como círculo vicioso) (NIETZSCHE, 1992a, p. 59), se torna, em contrapartida, a divisa de sua afirmação da vontade:

\begin{abstract}
E se um dia, ou uma noite, um demônio the aparecesse furtivamente em sua mais desolada solidão e dissesse: "Esta vida, como você a está vivendo e já viveu, você terá de viver mais uma vez e por incontáveis vezes; e nada haverá de novo nela, mas cada dor e cada prazer e cada suspiro e pensamento, e tudo o que é inefavelmente grande e pequeno em sua vida, terão de lhe suceder novamente, tudo na mesma seqüência e ordem - e assim também esse instante e eu mesmo. A perene ampulheta do existir será sempre virada novamente - e você com ela, partícula de poeira!" (NIETZSCHE, 2001, p. 204-5).
\end{abstract}

Se o demoníaco dizer Sim do eterno retorno é ao mesmo tempo uma negação dos instintos fracos - do "gênio [Fee] maldoso" do romantismo, diz ele em Além do bem e do mal (NIETZSCHE, 1992a, p. 17) - , um abraçar a inescapável realidade da dor e do sofrimento, em suma, se é necessário pensar aqui também em uma forma de pessimismo, que seja então denominado de pessimismo dionisíaco em contraposição ao pessimismo romântico. Este último é o pessimismo do empobrecimento de vida que pode se dar de dois modos: 1) como destruição pelo ódio, o malogro, a embriaguez, loucura e a revolta (anarquismo) ${ }^{58}$; ou 2) como fome de eternidade, de fixação, de silêncio, redenção de si (Schopenhauer e Wagner). 0 dionisíaco também pode ser encarado a partir desta dupla perspectiva: 1) como destruição pela mudança, devir, excesso de energia; ou 2) como abundância:

\footnotetext{
${ }^{57}$ Quando, por exemplo, o filósofo se refere à sua curiosidade, ao seu amor à verdade, como o "mais agradável dos vícios" (NIETZSCHE, 1992a, p. 52).

58 "Uma dinamite do espírito, uma niilina [neologismo nietzschiano] russa recém-descoberta" (NIETZSCHE, 1992a, p. 112).
} 
permissibilidade do mau, do feio, devido ao "excedente de forças geradoras, fertilizantes" (NIETZSCHE, 2001, p. 273).

\section{AUSGANGSLOSIGKEIT: OS LABIRINTOS DO NADA NÃO TÊM SAÍDA}

A análise schopenhaueriana da moral havia nos colocado diante daquela distância que separa a virtude moral (cujo tronco comum é o fenômeno da compaixão) e o ascetismo. No primeiro caso, como ocorre com o ato justo ou caridoso, temos ainda um agir por motivos, ainda que esta motivação seja o bem alheio. No caso do asceta, todas as formas do principio de individuação foram abandonadas, ocorreu uma negação completa da vontade (diferentemente da negação incompleta da ação virtuosa), não há qualquer relação com uma motivação externa. A negatividade da experiência do santo torna mesmo o discurso filosófico impotente: não se pode referir a este tipo de vivência senão que indiretamente, de modo metafórico, pois que as formas do conhecimento são incapazes de representar o não-representável. Cabe agora verificarmos em Nietzsche como se comporta sua crítica do niilismo diante desta distinção schopenhaueriana.

Como vimos, a crítica à moral da compaixão acompanha os escritos nietzschianos desde sua primeira publicação. O ascetismo ganha, contudo, uma abordagem mais pormenorizada em sua terceira dissertação da Genealogia da moral, pequeno ensaio polêmico sobre as raízes de todo sistema moral que 
acompanha seu Além do bem e do mal. Sabemos que o niilismo em Nietzsche ganha diversas figurações e isto se dá justamente porque são também diversificadas as formas em que a Vontade de poder se manifesta (vontade de conhecer ${ }^{59}$, de viver etc.). Diferentemente de Schopenhauer, no entanto, o niilismo do ascetismo não será de modo algum um estado de não-querer, um nada de vontade, mas antes uma vontade de nada, um querer o nada. De fato, Schopenhauer compreendia a compaixão e o ascetismo como fenômenos da negação da vontade, ainda que em graus distintos. Se, por outro lado, Nietzsche vê na atitude negativa do asceta também uma manifestação da vontade de poder (como o era também no compassivo, pois que sua relação com o sofredor era de domínio: o indivíduo digno de compaixão era uma potencial propriedade para o deleite daquele), resta-nos verificar em que sentido uma auto-anulação como a do santo ou monge (esta fuga do mundo em direção ao recolhimento em si do ascetismo) ${ }^{60}$ pode ser ainda um impulso de apropriação; em suma, se o nada querer é ainda um querer - e na linguagem nietzschiana todo querer é vontade de poder, de dominar - pergunta-se: o que quer afinal o asceta dominar? Em direção a que se dirige sua necessidade de domínio?

A resposta de Nietzsche põe em xeque algo essencial na metafísica da Vontade schopenhaueriana: a unidade da Vontade. Ela é, como foi dito, múltipla, um complexo de vontades e subvontades, e em sua multiplicidade - na constituição de uma determinada forma de organismo individual - vemos também o anseio pelo domínio e o conflito entre as potências mais fracas e as mais fortes: "um homem que quer - comanda algo dentro de si que obedece, ou que ele acredita que obedece" (NIETZSCHE, 1992a, p. 24). Isto posto, fica "aberto o caminho para novas versões e

\footnotetext{
59 "A minha vontade de poder caminha com os pés da tua vontade de conhecer a verdade!", lemos no diálogo entre Zaratustra e a vida (NIETZSCHE, 2003, p. 146).

${ }^{60}$ Em outras palavras: "neurose religiosa, solidão, jejum e abstinência sexual [...] convulsão de penitência e negação do mundo e da vontade" (NIETZSCHE, 1992a, p. 53).
} 
refinamentos da hipótese da alma: e conceitos como 'alma mortal', 'alma como pluralidade do sujeito' e 'alma como estrutura social dos impulsos e afetos' querem ter, de agora em diante, direitos de cidadania na ciência" (NIETZSCHE, 1992a, p. 19-20).

O niilismo pode a partir disto ser definido como um "sinal de uma alma em desespero, mortalmente cansada" naquele que prefere "um nada seguro a um algo incerto para deitar e morrer" (NIETZSCHE, 1992a, p. 16). Neste, a potência mais fraca obtém o domínio e nesta maldade e violência contra si o indivíduo pode não obstante conseguir um certo quinhão de prazer: "há também um gozo enorme, imensíssimo, no sofrimento próprio, no fazer sofrer a si próprio" (NIETZSCHE, 1992a, p. 136). Há aqui, no entanto, nesta busca doentia pelo prazer, uma mortificação absurda de si mesmo: "eliminar a vontade inteiramente, suspender os afetos todos sem exceção, supondo que o conseguíssemos: como? - Não seria castrar o intelecto?" (NIETZSCHE, 1998, p. 109). Mesmo na vontade de conhecer o essencial, pode-se reconhecer traços deste masoquismo do espírito, pois este busca por natureza a aparência e a superfície.

Vemos, pois, que Nietzsche não pretende simplesmente criar um sistema de Ética que se contraponha aos existentes no seu tempo (a maioria desprendida do mesmo solo kantiano), mas antes denunciar o moralismo imiscuído até mesmo onde a aparência de extremo ateísmo e o mais gélido racionalismo parecem guiar a pena do filósofo. Trata-se de percorrer os labirintos do Nada - esta negra oficina dos ideais (NIETZSCHE, 1998, p. 37) - e desvelar suas raízes, descrever sua genealogia. É deste modo que mesmo o pensamento consciente será incluído entre as atividades instintivas, ou melhor, que "em sua maior parte, o pensamento consciente de um filósofo é secretamente guiado e colocado em certas trilhas pelos seus instintos" (NIETZSCHE, 1992a, p. 11). Dito de outro modo: "ao nosso impulso 
mais forte, o tirano em nós, submete-se não apenas nossa razão, mas também nossa consciência" (NIETZSCHE, 1992a, p. 81). A vontade de verdade repousa sobre outro impulso mais forte, a vontade de inverdade, de não-saber. Sendo assim, necessário se torna apontarmos para os instintos decadentes (diante dos quais o impulso para o conhecimento, para a verdade, é só um instrumento) que, na preocupação da conservação da espécie, procura desvalorizar a própria vida e os instintos que elevam o espírito.

Com este duro olhar de psicólogo Nietzsche pretende auscultar os fundamentos da moral schopenhaueriana. Já apontávamos, na análise da Ética de Schopenhauer (capítulo O fundamento da moral), a possível contradição inerente à sua tese da ação desinteressada da compaixão. Com Nietzsche vemos esta problemática colocada às claras, percebemos o quanto poderia haver de interesse e egoísmo no ato compassivo: se a dor alheia é percebida como minha (ainda que presente no outro, mas ainda minha), não deveria haver padecimento e piedade pelo sofrimento alheio, pois ele deixou de ser alheio; neste caso, tentar suprimir a dor do outro se torna uma auto-ajuda, o que seria pois egoísmo. Diz Nietzsche: "se as dores do mundo fossem juntadas numa só, quem poderia ousar dizer que a visão dela nos iria necessariamente seduzir e obrigar à compaixão, e desse modo à duplicação da dor?" (NIETZSCHE, 1992a, p. 37).

De fato, toda ação é interessada e deveriam mesmo ser valorizados os casos de extrema e egoísta manifestação de força: eis o período extramoral do qual Nietzsche pretende ser seu anunciador. "Não adianta", reclama o filósofo, "é preciso questionar impiedosamente e conduzir ao tribunal os sentimentos de abnegação, de sacrifício em favor do próximo, toda a moral da renúncia de si: do mesmo modo a estética da 'contemplação desinteressada' " (NIETZSCHE, 1992a, p. 40). Este novo período fará as moralidades anteriores se igualarem à astrologia e à alquimia: com 
estas palavras Nietzsche confirma o que era já o temor de Schopenhauer (conforme indicado antes, sobre a crítica deste ao ceticismo na moral).

A ciência da moral se mostra assim impotente e deve recorrer ao auxílio de outras ciências como a etimologia e até mesmo a economia: de fato, Nietzsche julga ser possível encontrar a origem do sentimento de culpa, da sacralidade do dever, da consciência etc., no ato da cobrança de uma dívida, na relação entre devedor e credor, no comércio, nos conceitos de compra, venda, troca e tráfico. O castigo, a penitência, é uma forma de compensação pelo dano sofrido, um direito à crueldade legalizado, ao gozo do contra-prazer oferecido ao credor através do sofrimento do devedor, pois "ver-sofrer faz bem, fazer-sofrer mais bem ainda" (NIETZSCHE, 1998, p. 56). Este prazer, proporcionado por esta justiça legal, é tanto maior quanto mais baixa a posição do credor na ordem social. Por outro lado a aceitação passiva do castigo é tornada uma necessidade por esta mesma sociedade, o sofrimento tornase uma punição constante por uma dívida ancestral (o pecado original) cujo credor é o próprio Deus. Contra os pessimistas, no entanto, dirá Nietzsche, poderia ser apontado o fato de que na época da crueldade inocente, sem consciência de culpa, era-se mais feliz, pois mais resistente à dor (bem diferente da afeminada sensibilidade dos modernos).

III. GENEALOGIA DO NIILISMO 
"O niilismo bate à porta", alerta Nietzsche - o "profeta maior e teórico do niilismo" (VOLPI, 1999, p. 43) - e indaga: "de onde vem este mais indesejável de todos os hóspedes?" (NIETZSCHE, 1980, XII, p. 125). Segundo Nietzsche, o niilismo pode também ser tomado como a lógica que marca a dinâmica da história do Ocidente, conduzida por um processo decadente, cujo princípio encontra-se na instituição dos valores morais cristãos, passando pela crise e perda destes valores (a "morte de Deus") culminando na transvaloração de todos os valores representada pelas idéias do Eterno retorno e do Super-homem.

Na Genealogia da moral este "grande nojo" que é o niilismo, a fuga budista para o nada, é tomada como a posição antípoda à do Super-homem: "esse anticristão e antinilista, esse vencedor de Deus e do nada - ele tem que vir um dia..." (NIETZSCHE, 1998, p. 85). Sua chegada, no entanto, nos reserva uma novidade: o niilismo é assimilado por Nietzsche a seu pensamento nos últimos traços de sua pena e tenderia a representar (como ocorre como outros conceitos criticados pelo filósofo) também a experiência de uma vivência nobre. O reconhecimento deste aspecto fundamentalmente negador ocorreu a Nietzsche, talvez um pouco tarde, como nos revela um póstumo do outono de 1887: "Que até o presente eu tenha sido fundamentalmente niilista, foi há pouco tempo que confessei a mim mesmo: tanto a energia como o abandono que eu como niilista, empreguei em avançar, enganaram-me acerca deste fato" (NIETZSCHE, 1980, XII, p. 407-8). Em seu texto intitulado Para uma caracterização do niilismo na obra tardia de Nietzsche, Clademir Araldi nos mostra de que maneira o niilismo ganha importância na obra do filósofo a partir de sua investigação sobre a moral, e nos adverte que este termo é constituído em sua obra sob a marca de uma ambigüidade fundamental: "o niilismo pode ser um sinal de força, de intensificação do poder do espírito, ou pode ser um sinal de fraqueza, de decadência do poder do espírito" 
(ARALDI, 1998, p. 76). Sendo assim, a afirmação de que a filosofia nietzschiana rejeita o niilismo schopenhaueriano deve levar em conta esta dupla concepção do conceito de niilismo em Nietzsche. De acordo com o próprio Nietzsche, sua filosofia seria niilista, mas no primeiro sentido, como sinal de força, enquanto afirmação da vontade e negação absoluta de qualquer existência extramundana como o queria a metafísica clássica. A filosofia schopenhaueriana, enquanto negadora da vida e de tudo o que se apresenta como motivo para a vontade e sua natureza insaciável, seria assim representante do niilismo decadente.

Podemos chamar, com Nietzsche, este último, que indica a fraqueza do espírito, de niilismo passivo, e o outro de niilismo ativo. Deixemos para o próprio Nietzsche a definição destes conceitos (conforme um póstumo que serviria à publicação de $A$ vontade de poder, levada a cabo pela irmã do filósofo):

Dadas essas duas compreensões, de que com o vir-a-ser nada deve ser alvejado e de que sob todo o vir-a-ser não reina nenhuma grande unidade em que o indivíduo pode submergir totalmente como em um elemento de supremo valor: resta como escapatória condenar esse inteiro mundo do vir-a-ser como ilusão e inventar um mundo que esteja para além dele, como verdadeiro mundo. Tão logo, porém, o homem descobre como somente por necessidades psicológicas esse mundo foi montado e como não tem absolutamente nenhum direito a ele, surge a última forma do niilismo, que encerra em si a descrença em um mundo metafísico, que se proíbe a crença em um mundo verdadeiro. Desse ponto de vista admite-se a realidade do vir-a-ser como única realidade, proíbe-se a si toda espécie de via dissimulada que leve a ultramundos e falsas divindades [...] Em suma: as categorias 'fim', 'unidade', 'ser', com as quais tínhamos imposto ao mundo um valor, foram outra vez retiradas por nós - e agora o mundo parece sem valor. (apud GIACÓIA, 1997, p. 36-37)

No primeiro instante, em que há a condenação do vir-a-ser como ilusão e a invenção de um mundo que esteja para além dele, temos o niilismo passivo, no qual se incluiria Schopenhauer; no segundo, em que há a descrença em um mundo metafísico, a admissão do vir-a-ser como única realidade (mais ainda: o querer que assim o seja), temos então o niilismo ativo nietzschiano: o Eterno retorno. Este último seria uma evolução natural do primeiro, sua radicalização, sua forma mais 
extremada: instaura-se aí a plena luminosidade do meio-dia, "onde já não falo com palavras, mas com raios", diz o filósofo (NIETZSCHE, 1995, p. 70). Eis o niilismo ativo: o autêntico Nada, "o nada (o 'contra-senso') eterno" (NIETZSCHE, 1980, XII, p. 214).

Numa comparação desta passagem acima com o Das três transmutações do espírito de Assim falou Zaratustra, parte I, poderíamos dizer que o primeiro estágio do niilismo, em suas diversas configurações equivaleria às fases do camelo e do leão (os estágios psicológicos percorridos pelo niilismo incompleto, da percepção de ausência de sentido no devir até a sua negação e fuga deste); a fase da criança, o niilismo em seu último estágio, é atingida quando o espírito assume e suporta o vir-a-ser tal como é, desejando este mundo assim desdivinizado, dado que "o ateísmo e uma espécie de segunda inocência são inseparáveis" (NIETZSCHE, 1998, p. 79). A propósito, acrescenta Michel Haar,

\begin{abstract}
estas três fases são constantemente repetidas em Nietzsche. Elas são o desenvolvimento ocidental: o camelo (que carrega o peso e se ajoelha) torna-se leão ('romper o coração pleno de veneração, no momento em que ele se sente mais amarrado); o leão torna-se criança, "inocência" certamente e "esquecimento ativo", mas também "grandes responsabilidades", a única metamorfose do niilismo [grifo do autor], contrariamente à decadência desordenada que se congela e sapateia a cada instante, que não pode aderir a nada, que é o esquecimento passivo, incapaz de amar assim como de odiar verdadeiramente (HAAR, 1998, p. 121-122).
\end{abstract}

Na terceira dissertação da Genealogia da moral Nietzsche analisa o ideal ascético colocando no divã Schopenhauer e Wagner. A tese desenvolvida deixa-se expressar explicitamente: o nada querer é, na verdade, um querer um nada, portanto ainda um querer, um horror vacui (NIETZSCHE, 1998, p. 88). A agudeza da crítica de Nietzsche nos faz deparar com a mudança radical na obra wagneriana, originada pelo seu espírito ascético que, em estado germinal, encontra na metafísica schopenhaueriana a ocasião adequada para florescer. A concepção da música como idéia metafísica destituída de qualquer resquício fenomenal (o que ainda 
ocorreria nas outras artes), como porta-voz do em-si, telefone do além, é incorporada à forma de sentir a realidade de Wagner (diga-se de passagem: também do jovem Nietzsche de O nascimento da tragédia). Dali para o ascetismo, conclui Nietzsche, está-se a um passo: "quem não desejaria", diz ele, "em consideração ao próprio Wagner, que ele houvesse se despedido de nós e de sua arte de outro modo, não como um Parsifal, e sim mais vitorioso, mais seguro de si, mais wagneriano - menos enganador, menos schopenhaueriano, menos niilista?" (NIETZSCHE, 1998, p. 91).

Segundo Nietzsche, a pergunta pelo significado do ideal ascético deve ser respondida diferentemente no que diz respeito aos artistas e aos filósofos. Quanto aos primeiros,

necessitam sempre de uma proteção, um amparo, uma autoridade estabelecida: os artistas não se sustentam por si sós, estar só vai de encontro a seus instintos mais profundos. Foi assim, por exemplo, que Richard Wagner tomou o filósofo Schopenhauer, quando "o tempo era chegado", como sua anteguarda, sua proteção (NIETZSCHE, 1998, p. 92).

O problema então é como entender a homenagem de Schopenhauer ao ideal ascético, na medida em que ele, ao contrário de Wagner que se rendeu ao espírito de sua época, foi antes o mais extemporâneo de todos (cuja solidão já era notada por Nietzsche em Schopenhauer como educador): "um homem e cavaleiro de olhar de bronze, que tem a coragem de ser ele mesmo, que sabe estar só sem esperar por anteguardas e indicações vindas do alto" (NIETZSCHE, 1998, p. 92). A resposta, Nietzsche encontra analisando a questão da arte desinteressada do terceiro livro de $O$ mundo como vontade e representação: o ideal ascético surge no horizonte do filósofo como escapatória a uma tortura, o desespero pela realidade inelutável do sofrimento. Eis o interesse ocultado pela estética schopenhaueriana: o do torturado que luta pela libertação de sua tortura. Trata-se de uma visão 
extremamente desconcertante da negação da vontade, do niilismo schopenhaueriano, pois o mergulho no Nada, o quietismo da vontade, representaria na verdade um potente ato de vontade: o querer direcionado ao Nada ao invés do nada querer, diz Nietzsche.

Destarte, o que se desvela no ascetismo é esta busca pelo que Nietzsche chamou de optimum, condições favoráveis para a expansão das forças (no caso de Schopenhauer, a intelectual) do sentimento de poder. Trata-se deste modo, conclui Nietzsche, do mais irrisório egoísmo, pois não é da existência em geral que se busca o cuidado, mas da salvação de si próprio: "ele não nega com isso 'a existência', antes afirma a sua existência, apenas a sua existência, e isso talvez ao ponto de não Ihe ser estranho este desejo perverso: pereat mundus, fiat philosophia, fiat philosophus, fiam! [pereça o mundo, faça-se a filosofia, faça-se o filósofo, faça-se eu!]" (NIETZSCHE, 1998, p. 97) ${ }^{61}$.

Constatamos entretanto que este mesmo refinado egoísmo embutido na proposta schopenhaueriana da negação da vontade também se afigura na afirmadora atitude do Super-homem. Esta é a conclusão a que chega David Cartwright em seu artigo Nietzsche's Use and Abuse of Schopenhauer's Moral Philosophy for Life, isto é, a idéia de salvação está presente tanto no santo quanto no Super-homem, em ambos, contudo, a salvação não atinge a existência, os outros, mas somente o próprio indivíduo (CARTWRIGHT, 1998, p. 49).

Como podemos perceber, a filosofia schopenhaueriana é colocada por Nietzsche no mesmo balaio que outras doutrinas como o cristianismo e o budismo. Há, contudo, uma dimensão do niilismo de Schopenhauer que talvez não seja notada nesta crítica nietzschiana à sua moral e que se revela a um olhar mais atento

\footnotetext{
${ }^{61}$ Numa crítica ao egoísmo em Sobre o fundamento da moral, Schopenhauer lança mão de uma citação semelhante: pereat mundus, dum ego salvus sim (pereça o mundo, mas que eu seja salvo) (SCHOPENHAUER, 2001c, p. 212).
} 
direcionado para as bases epistemológicas da negação da vontade schopenhaueriana. A concepção do Nada em $O$ mundo como vontade e representação está ligada às discussões em torno da problemática do conhecimento colocadas pela Crítica kantiana ${ }^{62}$.

Em Nietzsche, entretanto, o conceito tem uma outra origem: num âmbito muito mais político-moral que epistemológico, como em Schopenhauer:

Tanto quanto o Budismo, também o Cristianismo constitui-se como expressão religiosa da "vontade de nada", deste desejo negativo de abandono do mundo, renúncia e ascese, que também se exprime metafisicamente no pessimismo filosófico de Schopenhauer e, do ponto de vista político, na fúria revolucionária dos movimentos niilistas, que pretendem a destruição de toda ordem existente. (GIACÓIA, 1997, p. 87).

A fúria revolucionária a que se refere Oswaldo Giacóia representa a literatura russa do século dezenove, mais especificamente o romance Pais e filhos de Ivan Turgueniev, do qual Nietzsche cunhará o termo niilismo. O romance (lido por Nietzsche em uma tradução francesa de 1863) relata a estória de Basárov, o jovem niilista, que visita a propriedade rural de Nicolau Pietróvitch, o pai de seu amigo Arcádio. O niilista encontra o desafeto do tio de Arcádio, o conservador Páviel Pietróvitch, com quem tem discussões acaloradas:

- Quem é Bazárov? - perguntou sorrindo Arcádio. - Quer, meu tio, que lhe diga quem é de fato?

- Faça-me o favor, meu caro sobrinho.

- Ele é niilista.

$[\ldots]$

- Niilista - disse Nicolau Pietróvitch - vem do latim, nihil, e significa "nada", segundo eu sei. Quer dizer que essa palavra se refere ao homem que... em nada crê ou nada reconhece?

- Pode dizer: o homem que nada respeita - explicou Páviel Pietróvitch, voltando novamente sua atenção para a manteiga.

- Aquele que tudo examina do ponto de vista crítico - sugeriu Arcádio.

- Não é a mesma coisa? - perguntou Páviel Pietróvitch.

\footnotetext{
${ }^{62}$ O termo niilismo teve sua primeira aparição filosófica na Carta a Fichte de Jacobi de 1799, sendo usado para caracterizar a demolição promovida pela crítica de Kant e pelos pós-kantianos em relação aos princípios fundamentais da metafísica clássica. O niilismo foi também um conceito-chave na primeira fase do pensamento de Hegel (Cf. ARANTES, 1996). A partir daí, o conceito passa por um breve período de hibernação despertando na segunda metade do século XIX com Nietzsche.
} 
- Não, não é o mesmo. O niilista é o homem que não se curva perante nenhuma autoridade e que não admite como artigo de fé nenhum princípio, por respeito que mereça...

$[\ldots]$

- Vejo que essa doutrina não se refere a nós. Somos homens do século passado e supomos que, sem os princípios (Páviel Pietróvitch pronunciava esta palavra suavemente, à francesa; Arcádio, pelo contrário, proferia-a à russa, carregando a primeira sílaba), sem os princípios transformados, como você disse em artigos de fé, não é possível dar um passo, nem mesmo respirar. Vous avez changé tout cela, que Deus Ihes dê saúde e posto de general. Ser-nos-á muito agradável apreciar a sua obra, senhores... como se chamam mesmo?

- Niilistas - pronunciou claramente Arcádio.

- Bem. Antes havia hegelistas, hoje há niilistas. Veremos como poderão viver no vácuo, no espaço sem ar. Por enquanto, mano Nicolau Pietróvitch, toque a campainha e mande buscar meu chocolate, que já é tempo. (TURGUENIEV, 1971, p. 31-33)

Contudo, em Schopenhauer - filósofo predileto de Turgueniev (VOLPI, 1999, p. 40) - o niilismo deita raízes nas teorias do conhecimento que se mostravam na Alemanha pós-kantiana. A negação da vontade schopenhaueriana, procura retratar, antes de tudo, uma relação particular entre o intelecto (e suas categorias) e a vontade. O mundo como vontade e representação nada mais é que a descrição de um percurso em que o conhecimento percebe novas formas em que se estabelece a relação entre o sujeito e o objeto. Trata-se de um tipo de intuição pura, não relacional, em que as categorias de tempo, espaço e causalidade não mais funcionam.

De fato, Schopenhauer foi acima de tudo um grande teórico do conhecimento mais que um moralista; a partir daí e não do problema da negação da vontade ou da atividade do santo iniciara ele sua filosofia, como queria Nietzsche. Como Kant, foi extremamente preocupado com a reforma do conhecimento. A título de hipótese, diríamos que possivelmente tenha sido Heidegger o primeiro a perceber esta ruptura de paradigma (ao criticar as Hermenêuticas pós-kantianas de Schleiermacher e Dilthey) que distancia as teorias do conhecimento das filosofias da existência como a de Nietzsche e, até certo ponto, da fenomenologia de Husserl. Como diz Heidegger em um escrito anterior a Ser e tempo: 
Desde cedo a relação do estar-aí com o mundo foi primariamente determinada a partir dos modos de ser do conhecimento, ou, como se diz, o que, entretanto, não se cobre com a primeira expressão usada, a "relação do sujeito com o objeto" foi primeiramente concebida primariamente como "relação cognoscitiva" e então foi incorporada posteriormente uma assim chamada "relação prática" (apud STEIN, 1988, p. 24-25).

Nietzsche no entanto, o psicólogo do niilismo, quer revelar a ante-câmera do edifício teórico dos homens do conhecimento:

Esses negadores e singulares de hoje, esses irredutíveis em uma coisa, na exigência de asseio intelectual, esses duros, severos, abstinentes, heróicos espíritos que constituem a honra do nosso tempo, todos esses pálidos ateístas, anticristãos, imoralistas, niilistas, esses céticos, efécticos, hécticos do espírito [...] eles se crêem tão afastados quanto possível do ideal ascético, esses "espíritos livres, muito livres": e no entanto, eu aqui lhes revelo o que eles próprios não conseguem ver - pois estão demasiado próximos a si mesmos - : esse ideal é também o seu ideal [...] se jamais fui um decifrador de enigmas, quero sê-lo com esta afirmação! (NIETZSCHE, 1998, p. 138). 


\section{MAIS ALGUMAS APROXIMAÇÕES: EXPLÍCITAS OU NÃO TÃO EXPLÍCITAS}

\section{- A questão do estilo}

Em 1896, Machado de Assis escreve um conto intitulado O espelho. Nele o literato brasileiro (que alguns anos antes havia trabalhado em um jornal chamado Espelho) analisa com profundidade e refinado humor a natureza da alma humana. A tese na qual o homem tem duas almas (uma que olha de dentro para fora e outra de fora para dentro) nos remete à distinção entre um viver autenticamente, para si, e um viver inautêntico. Do representante deste último, o espelho reflete uma silhueta desfigurada, quase imperceptível. A busca da interioridade foi deixada de lado, ele não mais se vê, é um pálido reflexo de uma imagem construída pelo seu espelhamento nas convenções, no já instituído, na opinião alheia. O conhece-te a ti mesmo socrático já nos colocava diante de um pensamento semelhante. A lanterna de Diógenes, que procurava "o" homem, não encontrando nada além da ostentação dos homens comuns, era o símbolo de uma crítica mordaz ao viver inautêntico.

Contemporâneo de Machado de Assis, outro grande leitor de Arthur Schopenhauer, Friedrich Wilhelm Nietzsche (cuja autobiografia traz como subtítulo tornar-se o que se é) também foi seduzido em alguns momentos de sua obra pela metáfora do espelho.

Se a obra do autor de $O$ mundo como vontade e representação é um espelho, como afirma o próprio Nietzsche, é interessante imaginar quais imagens de Nietzsche foram ali refletidas nos diferentes momentos em que o pensamento nietzschiano passava de uma fase a outra. Em fases posteriores da obra de 
Nietzsche, este toma seus próprios escritos também como um espelho. Algo importante precisa ser dito: Schopenhauer ensinou Nietzsche a ser um espelho. Que imagens serão refletidas pelo espelho de Zaratustra?

$\mathrm{Na}$ época em que o jovem Nietzsche escreve a terceira Consideração extemporânea (Schopenhauer como educador), ele encontrava a sua própria imagem no espelho schopenhaueriano, conforme lemos em Ecce homo. "Schopenhauer e Wagner, ou, em uma palavra, Nietzsche...", sentencia o filósofo em sua autobiografia (NIETZCHE, 1995, p. 67). Contudo, este não era o único reflexo percebido: os escritos de Schopenhauer são o espelho de sua época, diz Nietzsche, e não é culpa do espelho "se tudo o que é atual só aparece como uma doença que desfigura, sob uma aparência magra e pálida, olhos fundos e semblante abatido, com sofrimentos marcados por esta infância bastarda" (NIETZSCHE, 1988a, p. 39). Por outro lado, sabe-se lá que tipo de criatura adoentada, pálida e abatida Nietzsche contemplava em seu próprio reflexo no espelho. O fato é que, a exemplo do conto machadiano (mas com outro significado), este reflexo foi perdendo seus contornos, esfumaçando-se, a ponto de Nietzsche não mais se ver ali refletido em fases posteriores de seu pensamento. Neste caso, seu próprio diagnóstico certamente seria aquele de uma "cura" de todo resquício metafísico. Agora, é o espelho de Zaratustra que não refletirá a figura de Schopenhauer.

Dado que os escritos de Nietzsche expressam, segundo ele, a experiência de vivências nobres, o filósofo havia planejado intitular seu Para além de bem e mal simplesmente de $O$ espelho (conforme podemos verificar em vários esboços de sua herança manuscrita). A explicação para isto encontra-se num fragmento póstumo: "E se este livro for um espelho e conseqüentemente uma oportunidade para autoespelhamento?" (apud ITAPARICA, 2002, p.76). De fato, "Para além de bem e mal é um tipo particular de espelho, pois, com seu estilo, permite a poucos a possibilidade 
de nele se reconhecer" (ITAPARICA, 2002, p.76). O espelho também seria o título de um volume de $A$ gaia ciência, pois seria um livro escrito apenas para espíritos livres: "Todas as mais sutis leis de um estilo têm aí sua procedência", diz ali Nietzsche, "elas afastam, criam distância, proíbem 'a entrada', a compreensão, como disse - enquanto abrem os ouvidos àqueles que nos são aparentados pelo ouvido" (NIETZSCHE, 2001, p. 284) ${ }^{63}$. O espelhamento, o olhar para si, em alguns indivíduos é mesmo insuportável, necessitam se observar sempre à distância: "O autoconhecimento não lhes é aconselhável" (NIETZSCHE, 2001, p. 67). Todos estes espelhamentos constituíram o ambiente em que se erigiu o objeto desta tese. Vejamos como isso se dá em relação à questão do estilo.

"O estilo é a fisionomia do espírito" diz Schopenhauer (SCHOPENHAUER, 2003b, p. 37). O estilo representa o caráter formal do pensamento de um escritor, e este caráter permanece inalterável independente do que tenha pensado ou sobre $o$ que tenha pensado - o que se segue da tese de Schopenhauer sobre o caráter inteligível, essência individual ou idéia platônica particular que no homem não é modificada nem mesmo com a morte ou com o fenômeno da negação da vontade (no ascetismo moral apresentado em sua ética). O título do suplemento ao quarto livro de $O$ mundo como vontade e representação que expõe tal tese (Sobre a morte e suas relações com a indestrutibilidade de nosso ser em si) já indica tal característica do caráter. O mesmo também se aplica ao estilo. É neste sentido que Schopenhauer analisa a questão da escrita e do estilo em três tratados dos Parerga e Paralipomena: Sobre o ofício do escritor e o estilo (cap. 23); Sobre leitura e livros (cap. 24); e Sobre a língua e as palavras (cap. 25). Em Nietzsche esta problemática também é a tônica predominante em vários momentos de sua obra. É interessante

\footnotetext{
63 "É difícil ser compreendido", afirma ele, em Além do bem e do mal, "sobretudo quando se pensa e se vive gangasrotogati [no ritmo do Gânges] entre homens que pensam e vivem diferente, ou seja, kurmagati [no ritmo da tartaruga] ou, no melhor dos casos, 'conforme o andar da rã', mandeikagati - vê-se que estou fazendo tudo para não ser compreendido" (NIETZSCHE, 1992a, p. 35).
} 
verificar então em que sentido os discursos de ambos a respeito deste assunto nos servem para refletirmos sobre os estilos de cada um, sobre a maneira particular com a qual tratam de certas temáticas para, a partir daí, compreendermos com mais nuanças as aproximações, entrecruzamentos ou distanciamentos de dois espíritos tão próximos e ao mesmo tempo tão antagônicos como são Schopenhauer e Nietzsche.

Boa parte das idéias e críticas destes textos de Schopenhauer já se encontra de algum modo dispersa nos escritos anteriores do filósofo. Aqui, são tratadas de forma direta e com exclusividade, sem uma maior preocupação com o conteúdo mais complexo de seu sistema exposto desde Sobre a quádrupla raiz do princípio de razão suficiente. A propósito, esta característica peculiar dos Parerga deve ser ressaltada: ao estilo de Balthasar Gracian (1601-1658) ${ }^{64}$, a maior parte de seus tratados e ensaios apresentam, ao modo panfletário, conselhos ou máximas para o bom procedimento em determinado assunto. No caso dos textos em questão, trata-se de distinguir os bons livros daqueles que não merecem nem mesmo ser lidos - "pois o tempo é precioso", reclama Schopenhauer (SCHOPENHAUER, 2003b, p. 4) - e de estabelecer os critérios da boa escrita, para que, através da denúncia dos erros se acerte a via correta para a exposição dos pensamentos. Nas palavras de Franco Volpi, no prefácio à tradução italiana daqueles capítulos dos Parerga, trata-se de "conselhos para bem praticar a escrita". (SCHOPENHAUER, 2003b, p. X).

A polêmica levantada aqui por Schopenhauer em relação às deficiências literárias de seu tempo ${ }^{65}$, encontra a mesma resposta dada por ele ao problema do ensino acadêmico da filosofia em outro ensaio dos Parerga (Sobre a filosofia

\footnotetext{
${ }^{64}$ Jesuíta e filósofo espanhol, de quem Schopenhauer traduziu o Oráculo manual, cujo estilo aforístico exerceria importante influência em seus escritos, em especial nos Aforismos para a sabedoria da vida dos Parerga $e$ Paralipomena.

${ }^{65} \mathrm{O}$ "período de desonestidade", diz ele em Sobre o fundamento da moral (SCHOPENHAUER, 2001c, p. 57).
} 
universitária), a saber, tudo se resume ao anseio pelo lucro, pelo ganho de um honorário, um ganha-pão, que traz como conseqüência uma má filosofia assim como uma má literatura: "o estado deplorável da literatura hodierna", afirma, "na Alemanha e no exterior, tem na sua raiz o fato de se ganhar dinheiro escrevendo livros". (SCHOPENHAUER, 2003b, p. 5). Schopenhauer constata que, em geral, tais escritores são professores ou literatos com baixos rendimentos e que necessitam complementar sua renda. A má literatura encontraria respaldo no gosto do público pelo novo em detrimento da boa qualidade. Outra grave conseqüência deste maltrato da literatura de um país seria a deterioração da língua, problema tratado com abundância de exemplos nos textos citados dos Parerga.

De imediato, esbarramos em uma constatação schopenhaueriana extremamente inquietante no que se refere ao problema do estilo: o complexo trajeto que conduz do pensamento à escrita. Para Schopenhauer, ao encontrar as palavras, o pensamento já não é nosso. Resta verificar a que distância se localiza o pensamento de sua origem, quando ele é cristalizado pela escrita. A citação de Goethe feita pelo filósofo nos mostra a extensão da problemática: "Não me confundais com contradições! Tão logo se fala, já se começa a errar" (do texto de Goethe: Spruch, Widerspruch). De fato, afirma Schopenhauer,

\footnotetext{
a pena é para o pensar o que a bengala é para o andar; mas o caminhar mais rápido é aquele sem bengala, e o pensamento mais perfeito vai por si mesmo sem a pena. Só quando começamos a envelhecer é que preferimos nos servir da bengala e da pena. (SCHOPENHAUER, 2003b, p. 20).
}

Se por um lado estamos conscientes, como nos lembra o filósofo, de que um livro nada mais é que a impressão dos pensamentos do autor, por outro lado não podemos fechar os olhos para este distanciamento que se verifica quando o pensamento veste a roupagem da linguagem. Dito de outro modo, o pensamento 
quando encontra a pena já não pertence ao autor, é como o filho que ganha a existência, diz Schopenhauer. Contudo, a citação acima parece também indicar a promoção de um déficit, uma espécie de degradação do pensar na transmutação para a linguagem - contudo, não devemos imaginar que há nisto uma apologia schopenhaueriana aos que, como Sócrates, não fizeram uso do discurso escrito: assim como um estilo ruim revela a pequeneza de espírito, a grandeza é suspeita, diz ele em outra parte dos Parerga (Fragmentos para a história da filosofia), diante do não uso da escrita: "é-me difícil acreditar no espírito verdadeiramente grande daqueles que não escreveram" (SCHOPENHAUER, 2003a. p. 32).

Alguns anos antes destas reflexões schopenhauerianas ganharem o papel, nas primeiras décadas do século XIX na Alemanha, uma ciência filosófica estava sendo criada para tratar de tais problemas: a Hermenêutica - ou Arte e técnica da interpretação, como a chamava Friedrich Schleiermacher (1768-1834), seu principal fundador. Nunca estaremos face a face com o pensamento de um autor, diz a Hermenêutica, pois o contexto histórico em que o discurso é proferido, a linguagem utilizada e o estilo (ou seja, uma forma particular com a qual uma individualidade trabalha os conceitos existentes em uma determinada língua) fazem com que devamos encarar uma obra como um véu que esconde um pensamento (o nome de Schleiermacher - "fazedor de véus" - se presta bem a este tipo de metáfora e Nietzsche sabia disto). É preciso interpretá-la, cotejando-a com o contexto histórico, lingüístico e psicológico donde brotou. Ademais, ao propor uma identificação entre pensamento e linguagem e tendo em vista o caráter histórico da linguagem, Schleiermacher chega à tese de uma total relatividade do pensamento, subvertendo princípios básicos do idealismo em voga, pois "historiciza e lingüisticiza o próprio transcendental kantiano" (SCHLEIERMACHER, 2001, p. 13). Não há em Schopenhauer um tratamento mais aprofundado deste assunto que preocupava os 
filólogos e exegetas de sua época. Schleiermacher foi professor de Schopenhauer na Universidade de Berlin (que aquele ajudou a fundar), mas não se sabe até que ponto Schopenhauer estava inteirado de suas teses sobre a Hermenêutica - a única referência em relação a ele em seus escritos diz respeito à teologia, pois era principalmente como teólogo que Schleiermacher era conhecido na época.

Certamente Schleiermacher veria com bons olhos a comparação feita por Schopenhauer entre a relação pensamento-escrita e o processo de cristalização na natureza. Por outro lado, neste último, a idéia de que o pensamento mais perfeito vai por si mesmo sem a pena, parece bater de frente com a inseparabilidade entre pensamento e linguagem prescrita pelo primeiro. Ainda que Schopenhauer tenha em mente a questão da escrita em detrimento da questão da interpretação, as duas estão interligadas, e a afirmação da possibilidade de um pensamento despido da linguagem, ou anterior a ela, torna a tese schleiermachiana problemática.

Poderíamos talvez indagar se não é exatamente nisto que pensava Nietzsche quando, a respeito do estilo, escreve que

quem pensa em palavras, pensa como orador e não como pensador (isto revela que ele não pensa as coisas, os objetos, não pensa objetivamente, mas apenas a propósito das coisas; que na verdade pensa em si e em seus ouvintes). (NIETZSCHE, 1998, p. 99).

Sabe-se que a constatação da limitação da linguagem levou Nietzsche a uma experimentação estilística que marcará seus escritos através da diversidade de formas de expressão, que visa superar tal limitação. Neste sentido,

a resposta de Nietzsche aos limites da linguagem seria fornecida, portanto, por seu estilo: existe um além da linguagem, que não é outro senão o seu aquém, não o puro silenciar, mas sim o ritmo originário, a canção pré-mundana, energia originária e ondulatória; resposta esta que aproximaria o último Nietzsche se sua concepção inicial da melodia dionisíaca originária. (ITAPARICA, 2002, p. 16). 
A aproximação mais surpreendente a ser notada aqui, é a que liga esta concepção musical do estilo e a afirmação schopenhaueriana do pensamento mais perfeito sem a pena: "também os próprios pensamentos", afirma Nietzsche em A gaia ciência, "não se pode reproduzir inteiramente em palavras" (NIETZSCHE, 2001, p. 181). Em O nascimento da tragédia diz o jovem filósofo, (referindo-se a Schiller):

\begin{abstract}
Ele confessou efetivamente ter tido ante si e em si, como condição preparatória do ato de poetar, não uma série de imagens, com ordenada causalidade dos pensamentos, antes um estado de ânimo musical ("O sentimento se me apresenta no começo sem um objeto claro e determinado; este só se forma mais tarde. Uma certa disposição musical de espírito vem primeiro e somente depois é que se segue em mim a idéia poética") (NIETZSCHE, 1992b, p. 43-4)
\end{abstract}

Veremos que a idéia do pensar objetivamente também perpassa a análise de Schopenhauer sobre o estilo.

Há, segundo ele, dois tipos de escritores: os que escrevem por amor ao assunto, que, portanto, têm vocação para isso; e os que escrevem por escrever, por dinheiro, por um honorário. Geralmente faltam clareza e precisão na escrita destes últimos, aos quais certamente se aplica a crítica de Nietzsche: "ele não tem tempo, ele mal crê em si mesmo, precisa falar hoje ou nunca" (NIETZSCHE, 1998, p. 100). Do mesmo modo, o outro estilo elogiado por Nietzsche como o do espírito seguro de si mesmo, que fala baixo e para o qual é estranho o brilho da fama, dos príncipes e das mulheres, se identificaria com o primeiro tipo descrito por Schopenhauer.

O autor dos Parerga diferencia ainda três tipos de autores: os primeiros são aqueles que escrevem sem pensar, a partir da memória ou diretamente de livros alheios. Estes seriam mais numerosos (a regra é a canalha, diz ele). Os segundos são os que pensam enquanto escrevem. Enfim, os mais raros são os terceiros, que pensam antes de escrever, pensam as próprias coisas e não o que foi dito por outrem. Em seus Fragmentos para a história da filosofia podemos encontrar alguns 
exemplos desses tipos. Ao falar da falta de profundidade e do caráter repetitivo do estilo aristotélico, classifica o estagirita como um dos que pensam com a pena na mão (um alívio para o escritor, diz Schopenhauer, mas um incômodo para o leitor). Platão seria o oposto de Aristóteles, pois refletiria antes de escrever (SCHOPENHAUER, 2003a. p. 39). Nietzsche expõe em verso - num poema sobre Sêneca: Seneca et hoc genus omne (Sêneca e os de sua espécie) - uma crítica semelhante (dos poemas que antecedem a Gaia ciência, intitulados Brincadeira, astúcia e vingança): " Escreve e escreve seu palavreado / Insuportavelmente sábio, / Como se devesse primum scribere, I Deinde philosophari [primeiro escrever, depois filosofar]" (NIETZSCHE, 2001, p. 33). Na mesma obra assevera Nietzsche: "eu não sou daqueles que pensam tendo na mão a pena molhada" (NIETZSCHE, 2001, p. 119), diferenciando-se daquele cujo acesso ao pensamento ocorre quando está "sentado em frente ao tinteiro, com o estômago apertado, a cabeça curvada sobre o papel" (NIETZSCHE, 2001, p. 268).

Em todo pensar, diz Schopenhauer, devem ser distinguidas a matéria e a forma. A matéria é aquilo sobre o qual se pensou; e a forma é o que se pensou sobre algo. O verdadeiro valor de um autor se encontra na forma do pensamento, pois uma obra pode se tornar célebre meramente devido à novidade do objeto, da matéria tratada (como a descrição de lugares distantes ou fenômenos naturais raros). É na observação da forma que podemos identificar a qualidade do estilo: é no modo como alguém pensa algo sobre alguma coisa que se encontram os traços que formam o estilo.

Tanto na crítica de Schopenhauer quanto na de Nietzsche, o principal critério para se analisar um escrito é a clareza. Isto que é prescrito pelos dois filósofos, os historiadores da filosofia nos acostumaram a notar nos próprios escritos de ambos. É bastante lembrado que uma das principais resistências dos 
contemporâneos ao pensamento de Schopenhauer dizia respeito à forma cristalina de seus escritos: "quando das profundezas e dos meandros dos textos dos idealistas passamos à leitura de Schopenhauer, temos de fato a impressão de entrar numa sala intensamente iluminada" (SCHOPENHAUER, 2003b, p. VIII. Prefácio de Franco Volpi).

Isto posto, assevera Schopenhauer, eis a primeira regra do bom estilo: ter algo a dizer, pois

quem tem algo a dizer que valha a pena ser dito não precisa escondê-lo por trás de preciosismos, frases difíceis e alusões obscuras; pode muito bem enunciá-lo de modo simples, claro e ingênuo, e estar certo de que suas palavras não perderão o efeito. Sendo assim, quem recorre aos artifícios já mencionados trai sua pobreza de idéias, de espírito e de conhecimento. (SCHOPENHAUER, 2003b, p. 46).

Deve-se portanto evitar "um estilo tão profundo e científico, que o leitor acaba sendo martirizado até a morte pelo efeito narcótico de períodos longos e vazios de pensamentos" (SCHOPENHAUER, 2003b, p. 41). Os adeptos deste estilo procuram vender palavras por pensamentos, dado que a falta de clareza na escrita significa igualmente falta de clareza no pensamento. No fundo, a obscuridade esconde o fato de não saberem ao certo o que querem dizer. Esta máscara da ininteligibilidade fôra introduzida primeiramente, segundo Schopenhauer, pelos pseudofilósofos das Universidades, mais especificamente por aqueles a quem ele chama de os três sofistas:

Foi introduzida por Fichte e aperfeiçoada por Schelling, alcançando por fim em Hegel seu clímax: sempre com maior êxito [...] não há nada mais fácil do que escrever de maneira que ninguém entenda, como não há, ao contrário, nada mais difícil do que expressar pensamentos significativos de modo que todos devam entender. (SCHOPENHAUER, 2003b, p. 43).

Portanto, o pensador verdadeiro se expressará sempre com clareza, segurança e brevidade, pois "a simplicidade sempre foi uma característica não 
apenas da verdade, mas também da genialidade [...] escrever de modo obscuro ou ruim significa pensar de maneira indistinta ou confusa" (SCHOPENHAUER, 2003b, p. 45) como o fazem as cabeças comuns ou cabeças-ocas, como designa Schopenhauer, que também se lembra de chamar a atenção para um defeito da língua alemã que propicia a escrita em períodos excessivamente longos (com várias intercalações de orações subordinadas) os quais são comparados a "gansos assados e recheados com maçãs, períodos que não podemos começar a ler sem antes olhar para o relógio". (SCHOPENHAUER, 2003b, p. 123). Encontramos em Nietzsche semelhante crítica à língua vernácula e a tortuosidade do estilo fruto de um gosto rococó: "tudo que é grave, arrastado, solenemente canhestro, todos os gêneros prolixos e monótonos de estilo se desenvolveram em rica variedade entre os alemães" (NIETZSCHE, 1992a, p. 35). É saudável também a predileção pela expressão mais concreta ao invés da mais abstrata; visa-se assim a clareza da exposição: "deve-se usar palavras comuns e dizer coisas incomuns, mas eles fazem o inverso", conclui Schopenhauer. (SCHOPENHAUER, 2003b, p. 53). Deve-se igualmente evitar a verborragia e o modo de se expressar enigmático, subjetivo; Schopenhauer adverte-nos que as pessoas escrevem, na maioria das vezes, um monólogo, sendo que toda escrita deveria ser um diálogo com o leitor. Pode-se afirmar que o pensamento obedece à lei da gravidade, diz ele: é muito mais fácil o caminho da cabeça ao papel do que o inverso. A prolixidade, o discurso rebuscado tem seu lugar entre os 38 estratagemas da argumentação sofística, expostos na Dialética erística, um escrito póstumo de Schopenhauer do período berlinense.

O resultado do estilo pesado se vê no fastio e aborrecimento causado no leitor, que podem ser de dois tipos: o aborrecimento objetivo, segundo o filósofo, se dá a partir da falta de pensamentos claros por parte do autor; e o aborrecimento 
subjetivo se refere a uma limitação do leitor e a falta de interesse pelo objeto tratado (que pode ser contornado pelo talento do escritor).

A simplicidade é outro adjetivo a ser notado no que se refere à qualidade do estilo: simplex sigilum veri (o simples é o sinal do verdadeiro), diz Schopenhauer em Sobre o fundamento da moral (SCHOPENHAUER, 2001c, p. 75) ${ }^{66}$. Em seus Fragmentos para a história da filosofia o filósofo identifica simplicidade com verdade e acrescenta, a respeito de sua própria obra: "Quase nenhum sistema filosófico é tão simples e composto de tão poucos elementos como o meu, podendo, por isso, ser facilmente visto e apreendido com um olhar." (SCHOPENHAUER, 2003a, p. 118). Boa parte deste tratado dos Parerga trata mais do estilo dos filósofos do que propriamente de suas doutrinas. Assim, a obra de Estobeu é considerada "uma exposição pedante, escolar, extremamente prolixa, inacreditavelmente insossa, banal e sem espírito da moral estóica, sem força e vida, sem pensamentos valiosos, precisos e sutis" (SCHOPENHAUER, 2003a, p. 43). O estilo de Epiteto é considerado fácil e fluente, mas prolixo; aos Neoplatônicos falta "forma e desembaraço na exposição" com a exceção de Porfírio que "escreve clara e coerentemente, de modo que o lemos sem má vontade", ao contrário de Proclo que é considerado "um tagarela superficial, prolixo e insípido" (SCHOPENHAUER, 2003a, p. 46-47). Plotino tem um estilo ruim, acrescenta Schopenhauer, "seus pensamentos não são organizados, nem previamente refletidos, mas ele escreveu a torto e a direito, como the aprazia". (SCHOPENHAUER, 2003a, p. 48). Na Crítica da filosofia kantiana (o apêndice a $O$ mundo como vontade e representação) o estilo de Kant é caracterizado como de uma brilhante secura, lembrando, para Schopenhauer, a arquitetura gótica,

\footnotetext{
${ }^{66}$ Schopenhauer encontra a inscrição no túmulo de um médico numa igreja na cidade de Leiden, na Alemanha.
} 
pois uma peculiaridade bem individual do espírito de Kant é o gosto singular pela simetria, que ama a multiplicidade variegada, para ordená-la e para repetir a ordenação, em subordinações e assim por diante, exatamente como nas igrejas góticas. Ele chega a levar isto, às vezes, até o lúdico, quando, por amor dessa inclinação, vai tão longe a ponto de fazer violência manifesta à verdade e lidar com ela como lidavam com a natureza os jardineiros góticos, cuja obra são aléias simétricas, quadrados e triângulos, árvores piramidais e esféricas e sebes retorcidas em curvas regulares. (SCHOPENHAUER, 1980, p. 97)

Que Schopenhauer produziu uma obra filosófica marcada por um estilo bem mais leve que o de seus contemporâneos, nós o sabemos. Seus escritos são o contra-exemplo mais evidente do style empesé criticado por ele. Entretanto, uma peculiar característica da irritada pena de Schopenhauer precisa ser destacada: até as linhas dos escritos mais sérios do filósofo convidam, a todo instante, ao riso fácil. O humor às vezes sarcástico, outras vezes raivoso, surpreende o leitor mais compenetrado. É uma arma poderosa contra os que ele chamava de inimigos da verdade. Este amor pela verdade será bem notado pelo mais célebre daqueles de quem foi um "educador". Uma outra relação amorosa (talvez não pensada por Nietzsche) convém ser lembrada: o amor do filósofo pelos seus escritos. Isto nos põe a pensar que talvez seja esta uma das razões da grandeza de sua obra, acreditando, como ele mesmo nos mostra, que há dois tipos de literatura: uma real (permanente, das pessoas que vivem para a poesia ou para a ciência) e outra aparente (que passa, de pessoas que vivem da poesia ou da ciência). (SCHOPENHAUER, 2003b, p. 149). Deste modo podemos entender a distinção feita por Nietzsche em A gaia ciência, para quem

os livros e manuscritos são coisas diferentes em diferentes pensadores: um recolhe no livro as luzes que velozmente soube furtar e carregar consigo, dos raios de um conhecimento que sobre ele relampejou; um outro dá apenas as sombras, as imagens em preto e cinza daquilo que na véspera se edificou em sua alma (NIETZSCHE, 2001, p. 117).

Schopenhauer escreveu de forma extremamente apaixonada cada traço de tinta; a irritação do filósofo, as exclamações, afloram e gritam nas palavras 
difamadoras de suas críticas. Sua filosofia, mesmo nos assuntos mais complexos, não é um mero recorte de conceitos frio e abstrato, senão que incita a todo o momento um diálogo com o leitor - não é de se admirar por isto o fascínio que exerce entre literatos de diferentes culturas como Turgueniev, Thomas Mann, Borges e Machado de Assis.

Consta na biografia de Schopenhauer uma anedota em que o filósofo, em suas refeições diárias num restaurante, instituiu o hábito de depositar sobre a mesa uma moeda de ouro e embolsá-la novamente ao sair. Indagado pelo garçom, ele explica que fizera uma aposta consigo mesmo, prometendo doar a moeda a uma casa de caridade quando os militares, que freqüentavam o lugar, conversassem um dia sobre outro assunto que não fosse mulheres e cavalos. Em seus escritos, o comportamento não é diferente. A irritabilidade e a irreverência do autor de $O$ mundo em alguns momentos the custou (em certa medida) aquilo que ele buscou sem sucesso durante quase toda a sua vida: o reconhecimento. O maior flagrante disto são as últimas palavras do julgamento da Sociedade Real Dinamarquesa de Ciências, que não premiou seu ensaio Sobre o fundamento da moral no concurso iniciado em 1837 (mesmo sendo o único concorrente): “Também não se pode calar o fato de que o autor menciona vários excelentes filósofos contemporâneos de modo tão indecente, o que provoca justa e grave aversão" (SCHOPENHAUER, 2001c, p. 226). Irritado com certas mudanças promovidas, segundo ele, de modo irresponsável na língua alemã pelos jornalistas, Schopenhauer relata sua reação ao encontrar (num jornal de Göttingen) uma frase em que o pretérito mais-que-perfeito fora substituído irregularmente pelo imperfeito: "Não pude deixar de exclamar: 'velhaco miserável'!" (SCHOPENHAUER, 2003b, p. 65). Quanto rancor contra a deturpação daquilo que the era tão caro! O empobrecimento da língua representava para ele o empobrecimento do espírito de uma nação. Por isto não se poderia 
esperar de sua parte uma forma mais amena de se expressar para se referir aos recenseadores anônimos:

\begin{abstract}
Deveria ser destruído aquele escudo de toda velhacaria literária: o anonimato [...] toda menção a um recenseador anônimo, mesmo que totalmente casual e sem crítica, deveria ocorrer mediante epítetos, como "o velhaco anônimo e covarde não sei de onde" ou "o patife anônimo encapotado em tal revista", e assim por diante [...] Uma impertinência particularmente irrisória de tais críticos anônimos é que eles, como os reis, falam por nós, enquanto deveriam falar não apenas no singular, mas também no diminutivo, ou melhor, no "humiliativo"; por exemplo, "minha pequenez miserável, minha manha covarde, minha incompetência dissimulada, minha velhacaria mesquinha" etc. Esta é a fala que convém a vigaristas encapuzados, a esses angüinhas que sibilam do buraco escuro de uma "revisteca literária" [...] O anonimato é na literatura o que a falcatrua material é na comunidade burguesa. "Nomeia-te, velhaco, ou cala-te" deve ser a divisa. Nesse sentido, pode-se logo completar, quanto à crítica sem assinatura: vigarista! [...] com seus ataques, o senhor anônimo é, sem mais, o senhor patife [...] Da minha parte, preferia presidir uma casa de jogos ou um bordel a uma toca de recenseadores anônimos. (SCHOPENHAUER, 2003b, p. 28-37).
\end{abstract}

Nietzsche não deixou passar despercebida esta característica do estilo schopenhaueriano: sua loquacidade da ira - diz ele, em A gaia ciência, aproximando Schopenhauer a Lutero (NIETZSCHE, 2001, p. 121). Até que ponto, poder-se-ia indagar, teria sido o próprio Nietzsche influenciado pela irascibilidade de Schopenhauer? A respeito do ateísmo deste, Nietzsche nos revela esta particular forma do filósofo de Danzig tratar a pena: "A profanidade da existência era para ele algo dado, tangível, indiscutível; ele perdia sua compostura de filósofo e se encolerizava toda vez que alguém mostrava hesitação e fazia rodeios nesse ponto" (NIETZSCHE, 2001, p. 255). A crítica psicológica de Nietzsche é ainda mais contundente nesta passagem da Genealogia:

Sobretudo não subestimemos o fato de que Schopenhauer, que tratava realmente como inimigo pessoal a sexualidade (incluindo seu instrumento, a mulher, este instrumentum diaboli [instrumento do diabo]), necessitava de inimigos para ficar de bom humor; o fato de que amava as palavras furiosas, biliosas e de cor escura [grifo nosso]; de que se enraivecia por se enraivecer, por paixão; de que teria se tornado um pessimista ( - o que não era, por mais que o desejasse) sem os seus inimigos, sem Hegel, sem a mulher, a sensualidade e toda a vontade de existência, de permanência. (NIETZSCHE, 1998, p. 96). 
Ao que tudo indica, o diagnóstico nietzschiano em relação ao estilo de Schopenhauer parece identificar-se com aquele apresentado na Genealogia em relação ao fenômeno da negação da vontade da moral ascética deste último. Tratase de uma velada afirmação de potência mascarada por uma atitude negadora.

Em princípio, ao introduzir aqui a questão do estilo na obra nietzschiana, devemos contrapor a unidade de estilo que marca a obra de Schopenhauer à diversidade estilística dos escritos de Nietzsche. Em seu estudo sobre a relação entre o estilo e a moral na obra de Nietzsche, André Itaparica nos mostra que as variações de estilo em sua obra (aforismo, tratado, poesia, autobiografia, panfleto polêmico) acompanham a mudança de certas concepções filosóficas. (ITAPARICA, 2002, p. 17). Pode-se também verificar neste estudo que a concepção de estilo de Nietzsche está ligada, em qualquer fase de seu pensamento, a certa crítica à moralidade impregnada na tradição metafísica. Na fase intermediária de seu pensamento, são apresentados dois tipos de estilo: o estilo decadente e o superior. O primeiro, marcado por uma visão metafísico-moral da realidade, é a forma de expressão hermética e rebuscada. A clareza e a simplicidade são as marcas do estilo superior. O próprio Nietzsche aponta para as obras do seu período românticoschopenhaueriano (que antecedem a publicação de Humano, demasiado humano) como um exemplo do primeiro estilo, pois nesta época o filósofo ainda estava impregnado pelo fúnebre perfume de Schopenhauer, como é dito em Ecce homo em contrapartida, na terceira Extemporânea Nietzsche acreditava que adentrar a obra de Schopenhauer era "como penetrar numa floresta, onde se respira mais profundamente e se sente de imediato um profundo bem-estar". (NIETZSCHE, 1988a, p. 26). O rompimento definitivo com a metafísica de Schopenhauer e a visão de mundo aproximada ao conhecimento científico, trazem consigo a figura do espírito livre de Humano, demasiado humano e o estilo aforismático. O aforismo, diz 
ele em A gaia ciência, é uma forma de encarar problemas profundos como um banho frio, "entrando rapidamente e saindo rapidamente" (NIETZSCHE, 2001, p. 285). Um escrito póstumo de Nietzsche nos mostra bem a dinâmica desta mudança:

Há leitores que preferem o rumo e o tom algo pomposo e incerto dos meus antigos escritos ao que atualmente prefiro - a maior segurança possível na designação e maleabilidade em todo movimento, a ponderação cautelosa no uso de todo artifício patético e irônico. Tornamo-nos, contudo, paulatinamente, em tantos e grandes esforços, tão diferentes, tão estranhos, que, nesta oportunidade, em que mais uma vez lhes devo falar, gostaria de falar apenas sobre a mais anódina de todas as diferenças, a diferença do estilo [grifo nosso]. (apud ITAPARICA, 2002, p. 26).

O aforismo, trazendo consigo as características da concisão, da tranqüilidade e da maturidade, é visto por ele como a forma ideal para expressar esta nova visão sobre a moralidade despida de qualquer fundamentação metafísica (a moral fundada metafisicamente é um procedimento elogiado por Schopenhauer em Kant, como o segundo mérito de sua filosofia - o primeiro seria a distinção entre fenômeno e numeno). O estilo fragmentário do aforismo seria perfeitamente adequado a esta nova visão histórico-científica proposta por Humano, demasiado humano, pois a ciência vê a realidade de modo fragmentado, diferentemente da metafísica que "procura realizar uma interpretação total da realidade, utilizando, para isso, uma linguagem hiperbólica" (ITAPARICA, 2002, p. 46) - cabe lembrar que foi justamente Schopenhauer a introduzir o aforismo na filosofia, inspirado pelos escritores espanhóis, em seus Parerga e paralipomena.

Nietzsche explica ainda a diferenciação entre os dois estilos a partir da distinção entre o estilo do intelecto (claro e preciso) e o da vontade (metafísica), "que tudo obscurece com sua paixão, com seu excesso de sentimentos" (ITAPARICA, 2002, p. 48). Este último é, conforme fragmento póstumo da primavera de 1876, o "estilo do pensamento impuro" (pathos) ao passo que o primeiro é o "estilo sem sentimento [gefühlose]" (ethos) (NIETZSCHE, 1980, VIII, p. 285). A propósito, o tom 
schopenhaueriano nesta distinção é flagrante, ainda que Schopenhauer não se colocasse no segundo tipo, como certamente o faz Nietzsche:

\begin{abstract}
Ao nomear o estilo contra o qual ele combate, o estilo da vontade, Nietzsche explicita os seus adversários, Schopenhauer e Wagner, assim como faz uma descrição do romantismo que permanecerá em sua obra posterior. Schopenhauer é criticado, talvez injustamente [grifo nosso], como um pensador que necessita de um estilo truncado para ocultar a própria implausibilidade de suas idéias. Para Nietzsche, um grego como Platão, por exemplo, fruto de uma época de clareza e concisão, não entenderia o que Schopenhauer escrevia. (ITAPARICA, 2002, p. 48).
\end{abstract}

Tendo em vista tudo o que fora dito mais acima sobre o estilo na obra schopenhaueriana, a observação do comentador nesta passagem a respeito da injustiça desta crítica de Nietzsche nos leva a perguntar: de que Schopenhauer fala aqui Nietzsche? É curioso notar que todas as críticas direcionadas a Schopenhauer são as mesmas que este filósofo dirige a muitos da tradição e de sua época e que, reconhecidamente, não caracterizam a beleza estilística de seus escritos. A crítica em relação à longa periodização da língua alemã e até mesmo o lamento de Schopenhauer a respeito da aceitação pública da má literatura são reencontrados em Nietzsche: "o infortúnio dos escritores claros e agudos", lê-se em Humano, demasiado humano, "é que o tomam por superfície e por isso não se aplica a eles muito trabalho; e a fortuna dos obscuros é o leitor que se ocupa deles e subscreve a satisfação de seu zelo" (apud ITAPARICA, 2002, p. 49). Ou ainda (conforme a diferenciação entre ser e parecer profundo, feita em A gaia ciência): "quem sabe que é profundo, busca a clareza; quem deseja parecer profundo para a multidão, procura ser obscuro. Pois a multidão toma por profundo aquilo cujo fundo não vê: ela é medrosa, hesita em entrar na água" (NIETZSCHE, 2001, p. 166). Ademais, o reconhecimento da leveza do estilo de Schopenhauer pode ser constatado já no primeiro escrito do próprio Nietzsche: "Schopenhauer, em quem Richard Wagner 
enaltece, justamente por causa desse ponto, uma insuperável clareza e transparência de exposição..." (NIETZSCHE, 1992b, p. 98).

Há aqui uma contradição diante da qual parece desmoronar toda aquela argumentação nietzschiana sobre o estilo: como explicar que a filosofia de Schopenhauer, conduzida por uma visão metafísico-moral da realidade, seja marcada pela clareza e simplicidade do "estilo superior"? Um espírito décadent não deveria produzir um estilo decadente?

Dado que no último Nietzsche a questão do estilo decadente se liga então ao conceito central desta fase que responde pelo nome de niilismo, resta verificar se aqui também não se alojaria algum paradoxo como esse encontrado acima.

Sendo assim, talvez só nos reste afirmar, como o faz Michel Haar, que o filósofo produz uma figura imaginária e caricaturada de Schopenhauer:

Nietzsche reconhece que seu Schopenhauer não é aquele dos historiadores [...] mas uma figura colossal, quase mítica, em todo caso simbólica, do último filósofo do velho estilo, que esteve mais próximo de Platão do que qualquer moderno. Como imagem construída, Schopenhauer é o condensado e o resumo, às vezes esquemático, do niilismo de toda a tradição (HAAR, 1998, p. 126).

Ou ainda, como afirma o próprio Nietzsche em Ecce homo (a respeito da terceira Extemporânea): "De maneira igual serviu-se Platão de Sócrates, como uma semiótica [Semiotik] para Platão" (NIETZSCHE, 1995, p. 70). 


\section{CONCLUSÃo}

À guisa de conclusão nos resta indicar as tarefas ainda por serem cumpridas nesta tentativa de trilhar os labirintos do nada. Estamos conscientes de não ter encontrado ali a saída. Isto significa que a pesquisa não pretendeu esgotar os escritos de ambos os filósofos. Trata-se reconhecidamente de um trabalho não especializado, deste modo fica por ser efetuado ainda um estudo mais detalhado da herança manuscrita dos filósofos, assim como dos comentadores (a produção dos colegas brasileiros, neste sentido, e devido à nossa estadia na Alemanha, infelizmente não pôde ser melhor trabalhada - em especial, precisa ser citado o fato de a tradução de $O$ mundo de Schopenhauer feita por Jair Barbosa ter surgido já em período avançado da pesquisa, o que justifica a referência à deficiente tradução da Rés). Um caminho natural que este trabalho certamente abre é a via que conduz aos escritos heideggerianos sobre o niilismo, talvez o primeiro trabalho de peso, depois de Nietzsche, sobre o assunto.

Em relação às questões colocadas no início, parece-nos terem suscitado a oportunidade de explorarmos outros diversos problemas relacionados, encontrados no decorrer da pesquisa. A preocupação primeira da tese, a saber, indicar o lugar do niilismo schopenhaueriano na crítica de Nietzsche, foi direcionada para a classificação nietzschiana entre niilismo passivo e ativo. Sabemos que a literatura atual especializada sobre o autor já encontra uma certa ramificação desta classificação básica em vários sub-tipos do conceito em questão, o que poderia representar uma oportunidade de uma possível extensão da pesquisa e que exigiria 
certamente o manejo de literatura não trabalhada de Nietzsche nesta empreitada (como os póstumos, por exemplo).

Ainda quanto ao conteúdo propriamente da tese, algumas palavras complementares podem ser aqui acrescentadas. Fala-se hoje no meio acadêmico (na Alemanha isto não é diferente) do diletantismo do autor de Zaratustra. Sua nãoformação acadêmica em filosofia, a pouca leitura dos clássicos e a escassez do trato sistemático de temas que envolviam a filosofia de seu tempo, parecem levantar certas suspeitas sobre a eficácia da crítica direcionada à tradição filosófica que o antecedia. No entanto, pelo que constatamos nas páginas anteriores, mesmo problemas áridos que geravam acaloradas contendas na Europa pós-kantiana, relacionados, por exemplo, a certos conceitos dos tratados morais da época, encontram em Nietzsche uma solução surpreendente: é deste modo que a idéia de ação desinteressada presente em Schopenhauer (mas também em Kant) recebe uma crítica incisiva no âmbito do pensamento nietzschiano.

Acirrada foi sua luta contra o cristianismo e os seus mais imperceptíveis efeitos na cultura ou na filosofia. Neste combate a filosofia schopenhaueriana é tomada como mais um sintoma deste longo período de envenenamento da humanidade pela doutrina cristã. Além disto, apontou Nietzsche para o possível antídoto para este veneno: a tresvaloração de todos os valores que é representada por sua própria filosofia. Neste condensado ou semiótica em que se tornou o pensamento de Schopenhauer nas mãos de Nietzsche, não só a postura de reformador da teoria do conhecimento, de crítico do dogmatismo (que em certa medida também o era Nietzsche) e até mesmo o ateísmo do autor de 0 mundo são praticamente negligenciados, mas também todo o parentesco que poderia ligá-los. Ademais, tudo indica que Nietzsche vivera um outro ambiente deste conturbado início da contemporaneidade: "tanto a etimologia como as modalidades de 
propagação do conceito e das questões com o niilismo associadas remetem para um contexto dominantemente axiológico" (MARQUES, 1989, p. 66). Schopenhauer precisou ser negado enquanto aquilo que no próprio Nietzsche representava ainda qualquer resquício do envenenamento de que ele próprio também fôra vítima. 


\section{REFERÊNCIAS}

$\underline{\text { Obras de Schopenhauer }}$

SCHOPENHAUER, Arthur. Sämtliche Werke. Textkritisch bearbeitet und herausgegeben von Wolfgang Frhr. Löhneysen. Darmstadt: Wissenschaftliche Buchgesellschaft, 1968.

Editions de l'Anabase, 1992.

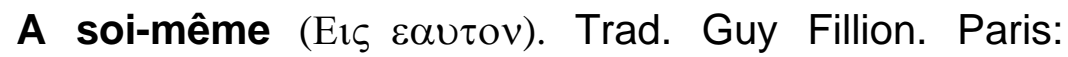

A arte de ter razão: exposta em 38 estratagemas. Organização e ensaio de Franco Volpi. Trad. Alexandre Krug e Eduardo Brandão. São Paulo: Martins Fontes, 2001a. (Breves encontros).

suffisante. Trad. J. Gibelin. Paris: Vrin, 1946.

De la quadruple racine du principe de raison . Essai sur le libre arbitre. Trad. Salomon Reinach. Paris:

Félix Alcan, 1900.

Fragmentos para a história da filosofia. Trad. Maria Lúcia Mello e Oliveira Cacciola. São Paulo: Iluminuras, 2003a.

. Le monde comme volonté et comme representation (Suplementos). Trad. A. Burdeau. 8. Ed. Paris: Félix Alcan, s/d-a.

. O mundo como vontade e representação (Livro III); Crítica da filosofia Kantiana; Parerga e Paralipomena (cap. 5, 8, 12 e 14). Trad. Wolfgang Leo Maar e Maria Lúcia Mello e Oliveira Cacciola. São Paulo: Abril Cultural, 1980. (Os Pensadores)

Sá Correia. Porto: Editora Rés, s/d-b.

O mundo como vontade e representação. Trad. M. F. . O mundo como vontade e representação. Trad. M. F. Sá Correia. Rio de Janeiro: Contraponto, $2001 b$.

Sobre a filosofia universitária. Trad. Maria Lúcia Mello e Oliveira Cacciola e Márcio Suzuki. São Paulo: Pólis, 1991.

Sobre la voluntad en la naturaleza. Trad. Herederos de Miguel de Unamuno. Madrid: Alianza Editorial, 1982. 
Sobre o fundamento da moral. 2. ed. Trad. Maria Lúcia Mello e Oliveira Cacciola. São Paulo: Martins Fontes, 2001c.

Sobre o ofício do escritor. Trad. Luiz Sérgio Repa. São

Paulo: Martins Fontes, 2003b.

Elie. Paris: Vrin, 1986.

Textes sur la vue et sur les couleurs. Trad. Maurice

Obras de Nietzsche

NIETZSCHE, Friedrich Wilhelm. Sämtliche Werke. Kritische Studienausgabe in 15 Bänden. Herausgegeben von Giorgio Colli und Mazzino Montinari. Berlin/München: Walter de Gruyter \& Co./DTV, 1980.

Paulo: Companhia das letras, 2001.

A Gaia ciência. Trad. Paulo César de Souza. São

Além do bem e do mal: prelúdio a uma filosofia do futuro. Trad. Paulo César de Souza. São Paulo: Companhia das letras, 1992a.

Assim falou Zaratustra: um livro para todos e para ninguém. Trad. Mário da Silva. 12. ed. Rio de Janeiro: Civilização Brasileira, 2003.

Considérations inactuelles III: Schopenhauer éducateur. In: Ouvres philosophiques completes. Trad. Henri Alexis Baatsch. Paris: Gallimard, 1988a.

Ecce homo: como alguém se torna o que é. Trad. Paulo César de Souza. São Paulo: Companhia da Letras, 1995.

. Genealogia da moral: uma polêmica. Trad. Paulo César de Souza. São Paulo: Companhia da Letras, 1998.

O nascimento da tragédia, ou Helenismo e pessimismo. Trad., notas e posfácio J. Guinsburg. São Paulo: Companhia das Letras, $1992 \mathrm{~b}$.

Sur l'avenir de nos établissements d'enseignement. In: Ouvres philosophiques completes. Trad. Jean-Louis Backés. Paris: Gallimard, 1988b.

Santos. Rio de Janeiro: Ediouro, 1985.

Vontade de potência. Trad. Mário D. Ferreira dos 
Sobre Schopenhauer

CACCIOLA, Maria Lúcia Mello e Oliveira Cacciola. Schopenhauer e a questão do dogmatismo. São Paulo: Edusp, 1994.

BARBOZA, Jair Lopes. Infinitude subjetiva e estética: a recepção e assimilação dos conceitos de Natureza e Arte de Schelling em Schopenhauer. São Paulo: Universidade de São Paulo, 2000. (Tese de doutorado)

BRANDÃO, Eduardo. O conceito de matéria em Schopenhauer. São Paulo: Universidade de São Paulo, 2003. (Tese de doutorado)

DROIT, Roger-Pol (Org.). Presences de Schopenhauer. Paris: Editions Grasset \& Fasquelle, 1989.

DURANT, Will. A filosofia de Schopenhauer. Trad. Maria Theresa Miranda. Rio de Janeiro: Ediouro, s/d.

HÜBSCHER, Arthur. Denker gegen den Strom. Schopenhauer: Gersten-HeuteMorgen. Bonn: Bouvier, 1982.

MAIA, Muriel Wanessa Torres. A outra face do nada - sobre o conhecimento metafísico na estética de Arthur Schopenhauer. Petrópolis: Vozes, 1991.

MALTER, Ruldof. Arthur Schopenhauers Tranzendentalphilosophie und Metaphysik des willens. Stuttgart - Bad Cannstatt: Frommann - Holzboog, 1991.

PENZO, Giorgio. Fichte und Schopenhauer - und das Nichts als Dimension des Heiligen. In: SCHIRMACHER, Wolfgang. Schopenhauers Aktualität: ein Philosoph wird neu gelesen. Wien: Passagen Verl., 1988.

PHILONENKO, Alexis. Schopenhauer, une philosophie de la tragédie. 2. Ed. Paris: VRIN, 1999.

RAMOS, Flamarion Caldeira. Tragédia e redenção: o significado moral da existência na filosofia de Schopenhauer. São Paulo: Universidade de São Paulo, 2003. (Dissertação de Mestrado)

RIBOT, Theodúle. La philosophie de Schopenhauer. Paris: Librairie Germer Baillière, 1874.

SALVIANO, Jarlee Oliveira Silva. O niilismo de Schopenhauer. São Paulo: Universidade de São Paulo, 2001. (Dissertação de Mestrado)

ROSSET, Clément. Schopenhauer, philosophe de l'absurde. Paris: PUF, 1989.

SANS, Edouard. Schopenhauer. Paris: PUF, 1990. 
Editions C. Klincksieck, 1969.

Richard Wagner et la pensée schopenhauerianne. Paris:

SIPRIOT, Pierre (Org.) Schopenhauer et la force du pessimisme. Paris: Ed. du Rocher, 1988.

WAISMANN, A. Cinco lecciones sobre la estetica de Schopenhauer. Cordoba: Publicaciones del instituto de Humanidades - Uni. Nac. de Cordoba, 1942.

WAISSMAN, Karl. Vida de Schopenhauer. Belo Horizonte: Itatiaia, 1980. (História e vida, 5)

$\underline{\text { Sobre Nietzsche }}$

ANDREAS-SALOMÉ, Lou. Nietzsche em suas obras. Trad. José Carlos Martins Barbosa. São Paulo: Ed. Brasiliense, 1992.

ARALDI, C. L. Para uma caracterização do niilismo na obra tardia de Nietzsche. Cadernos Nietzsche, 5, p. 75-94, São Paulo, USP, 1998.

CRAGNOLI, Mónica. Nietzsche, camino y demora. La Plata: Ed. Universitaria de La Plata, 1998.

DIAS, Rosa Maria. Nietzsche e Schopenhauer: uma primeira ruptura. In: FEITOSA, Charles; BARRENECHEA, Miguel Angel de; PINHEIRO, Paulo. A fidelidade à terra. Arte, natureza e política. Assim falou Nietzsche IV. Rio de Janeiro: DP\&A, 2003.

GIACÓIA JÚNIOR, Oswaldo. Labirintos da alma: Nietzsche e a auto-supressão da moral. Campinas-SP: Ed. Unicamp, 1997.

HAAR, Michel. Par-delà le nihilisme: nouveaux essais sur Nietzsche. Paris: PUF, 1998.

ITAPARICA, André Luís Mota. Nietzsche: estilo e moral. São Paulo: Discurso Editorial; ljuí: Ed. Unijuí, 2002.

MARQUES, Viriato Soromenho. Nietzsche e Kant: em torno do niilismo. In: MARQUES, António (Org.). Friedrich Nietzsche: cem anos após o projeto "Vontade de poder - Transvaloração de todos os valores. Lisboa: Ed. Veja, 1989.

MARTON, Scarlett. Nietzsche, das forças cósmicas aos valores humanos. São Paulo: Ed. Brasiliense, 1990.

MÜLLER-LAUTER, Wolfgang. A doutrina da vontade de poder em Nietzsche. São Paulo: Anna Blume, 1997. 
. Nietzsche: seine philosophie der Gegensätze und

die Gegensätze seiner Philosophie. Berlin: Walter de Gruyter, 1971.

KOSSOVITCH, Leon. Signos e poderes em Nietzsche. São Paulo: Ática, 1979.

$\underline{\text { Sobre a relação entre Schopenhauer e Nietzsche }}$

BRUM, José Thomaz. O pessimismo e suas vontades: Schopenhauer e Nietzsche. Rio de Janeiro: Editora Rocco, 1998.

CARTWRIGHT, David E. Nietzsche's Use and Abuse of Schopenhauer's Moral Philosophy for Life. In: JANAWAY, Christopher. Willing and Nothingness: Schopenhauer as Nietzsche's Educator. New York: Oxford University Press, 1998.

COPLESTON, Frederick. Schopenhauer and Nietzsche. In: FOX, Michael (Org.). Schopenhauer: his philosophical Achievement. New Jersey: Barnes \& Noble Books, 1980.

HÜHN, Lore. Die Wahrheit des Nihilismus: Schopenhauers Theorie der Willensverneinung im Lichte der Friedrich Nietzsches und Theodor W. Adorno. In: FIGAL, Günter (Hg.). Interpretationen der Wahrheit. Tübingen: Attempto, 2002.

SIMMEL, Georg. Schopenhauer y Nietzsche. Trad. Francisco Ayala. Buenos Aires: Editorial Schapire, s/d.

WISCHKE, Mirko. Die Geburt der Ethik - Schopenhauer-Nietzsche-Adorno. Berlin: Akademie Verlag, 1994.

Bibliografia complementar

ALVES JR., Douglas Garcia. Dialética da Vertigem: Adorno e a Filosofia Moral. São Paulo: Ed. Escuta, 2005.

ARANTES, Paulo Eduardo. Cruz Costa, Bento Prado Jr. e o problema da filosofia no Brasil - uma digressão. In: Salma T. Muchail (org). A filosofia e seu ensino. Petrópolis: Vozes; São Paulo: EDUC, 1995. (Série eventos)

Ressentimento da dialética: dialética e experiência intelectual em Hegel: antigos estudos sobre o $A B C$ da miséria alemã. Rio de Janeiro: Paz e terra, 1996.

HEGEL, G. W. F. Foi et savoir: Kant - Jacobi - Fichte. Trad. Alexis Philonenko e 
Claude Lecouteux. Paris: VRIN, 1988.

HEIDEGGER, Martin. Sobre o problema do ser. Trad. Ernildo Stein. São Paulo: Ed. Duas Cidades, 1969.

HORKHEIMER, Max. La actualidad de Schopenhauer. In: ADORNO \& HORKHEIMER. Sociologica. Trad. Víctor Sánchez de Zavala. Madrid: Taurus, 1971.

JACOBI, F.-H. Lettre a Fichte. In: Ouvres Philosophiques de Jacobi. Trad. J.-J Anstett. Paris: Aubier, s/d.

JANSON, H. W. Iniciação à história da arte. Trad. Jefferson Luiz Camargo. 2. Ed. São Paulo: Martins Fontes, 1996.

JÜNGER, Ernst. Sobre a linha. Trad. Marco Aurélio Werle. Cadernos de tradução, 3, p. 41-74, São Paulo, USP, 1998.

KANT, Immanuel. Crítica da razão pura. Trad. Valério Rohden e Udo Moosburger. São Paulo: Nova Cultural, 1999. (Os Pensadores)

. Essai pour introduire en philosophie le concept de Grandeur négative. Trad. Roger Kempf. Paris: VRIN, 1949.

MEUMANN, E. A estética contemporânea. Trad. Luís Feliciano dos Santos. Coimbra: Imprensa da Universidade, 1930.

PÖGGELER, Otto. Hegel und die Anfänge der nihilismus-diskussion. In: DIETER ARENDT (Org.). Der Nihilismus als Phänomen der Geistgeschichte. Darmstadt: Wissenchaftliche Buchgesellschaft, 1974.

SCHLEIERMACHER, F. D. E. Hermenêutica: arte e técnica da interpretação. Trad. Celso Reni Braida. Petrópolis: Vozes, 2001.

STEIN, Ernildo. Seis estudos sobre ser e tempo. Petrópolis: Vozes, 1988.

TURGUENIEV, Ivan. Pais e filhos. Trad. Ivan Emilianovitch. São Paulo: Abril cultural, 1971.

VOLPI, Franco. O niilismo. Trad. Aldo Vannucchi. São Paulo: Edições Loyola, 1999. 